\title{
الخصائص الريادية لدى قادة مدارس محافظة بيشة وعلاقتها بتعزيز الالتزام التنظيمي لدى المعلمين
}

\section{مخمد فيصال سعيد الرمثي}

الملخصص :

هدفت الدراسة إلى الكشف عن درجة توافر الخصائص الريادية لدى قادة المدارس بمحافظة بيشة وعلاقتها بتعزيز الالتزام التنظبسي للى المعلمبن، ولتحقبق هدف الدراسة تم استخدام المنهج الوصفي الارتباطي، وتم استخد/م الاستبانة كأداة للاراسة وتم تطبيقها على عبنة تم اختبار ها بطريقة عشوائية من

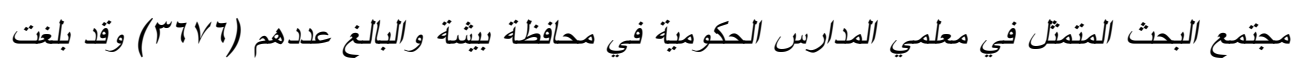
عبنة الدراسة النهائبة (350) مفرده، وأسفرت الدراسة عن عدة نتائج أهدها: أن درجة توافر الخصائص

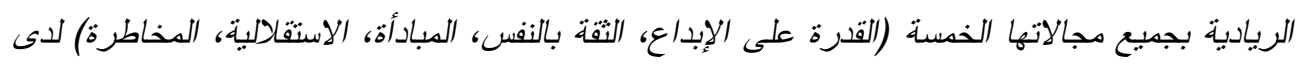
قادة المدراس الحكومية بدحافظة بيشة منوافرة بدرجة عالية، وكذلك درجة تعزيز قادة المدارس للالتزام

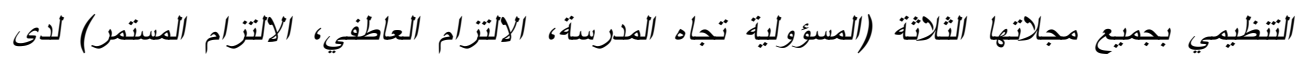
المعلمبن بددارس محافظة بيشة عالية، كما تبين عدم وجود فروق ذات دلالة إحصائية عند مستوى الدلالة

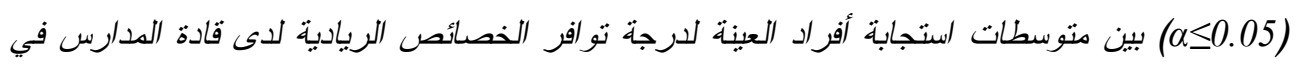

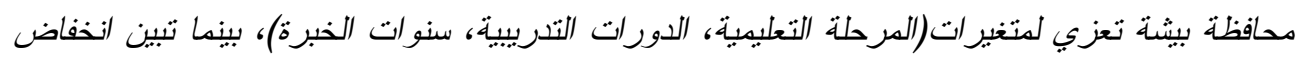
درجة توافر الخصائص الريادية بجميع مجالاتها لدى قادة المدارس التابعة لمكتب الوسط في محافظة بيشة

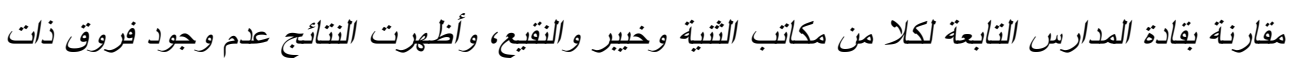

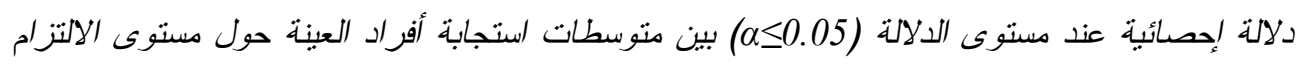
التنظيمي لدى المعلمبن بدحافظة بيشة تعزى لمتغبرات(المرحلة التعليمبة، الدورات التدربيية، سنوات الخبرة، مكتب التعليم التابعة لها المدرس)، كما تبين وجود علاقة ارتباطية موجبة ذات دلالة إحصائية عند مستوى الدلالة (1<0.05) بين نوافر الخصائص الربادية لدى قادة المدارس بدحافظة بيثة وتعزيز الالتزام التنظيسي لدى المعلين، وفي ضوء هذه النتائج قدمت الدراسة مجدوعة من التوصبات أهمها: العدل على تعزيز الخصائص الريادة لدى قادة مدارس محافظة بيثة من خلال الدورات وورش العدل، إقامة ندوات على مستوى المحافظة ومستوى المملكة ككل من أجل تعزيز الخصائص الريادة لدى قادة المدارس لما له دن أثر على الالتزام التتظبي للمعلمبن، حث قادة المدارس على إيجاد أساليب جديدة لتنفيذ مختلف المهام، بث روح المغامرة والمخاطرة المدروسة في نفوس قادة المدارس من خلال فتح المجالات

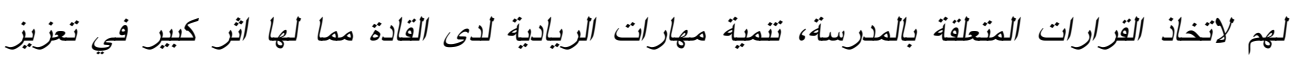
الالتزام التنظبيسي للمعلمبن، تتمبة روح الانتماء وحب المدرسة لدى المعلمبن. 


\section{Abstract}

This study aims to identify the pioneer characteristic degree among school leaders in Bisha Governorate and its relation in strengthening the organizational commitment of teachers. To achieve the objective of this study, the analytical descriptive method was used. A questionnaire was used as a tool to undergo this study, where was applied on a randomly selected sample for the research community, in which represented by leaders, teachers of public schools in Bisha Governorate, the sample was counted (3676) individuals, the final sample of the study counted (350). The study concluded the following: The pioneer characteristics in all its five areas (Creativity, Self-confidence, Openness, Independence, Risk) are available in a high degree among the leaders of the public schools in Bisha Governorate as well as the organizational commitment in all its three areas (Responsibility for school, emotional commitment, continuous commitment) among the teachers of public schools in Bisha Governorate. The results have showed that there were no statistically significant differences $(\alpha \leq 0.05)$ between the responses of the sample members of the pioneer characteristic degree of school leaders in Bisha Governorate to variables (educational stage, training courses, and years of experience). The results for the samples of school leaders of the central office in Bisha Governorate showed an average decrease in the pioneer characteristic degree in comparison with the school leaders of Al-Thnayah, Khaybar and Naqee offices. The results have showed that there were no statistically significant differences $(\alpha \leq 0.05)$ between the responses of the sample members of organizational commitment degree of teachers in Bisha Governorate to variables (educational stage, training courses, years of experience, and Education office affiliated schools). A significant positive correlation was found $(\alpha \leq 0.05)$ between the pioneer characteristic among school leaders in Bisha Governorate and its relation in strengthening the organizational commitment of teachers, In light of these results, the study has presented a number of recommendations: Enhancing the leadership qualities of school leaders at Bisha schools through workshops and courses, holding seminars at the governorate and the Kingdom in order to enhance the leadership qualities of school leaders as it has an impact on the organizational commitment of teachers, urging the school leaders to find new methods in performing various tasks, spreading the spirit of adventure and deliberate risk in the minds of the school leaders by opening up areas for them to make decisions related to the schools, developing the leadership skills among leaders has a significant impact on strengthening the organizational commitment of teachers, developing the spirit of belonging and school love in teachers.

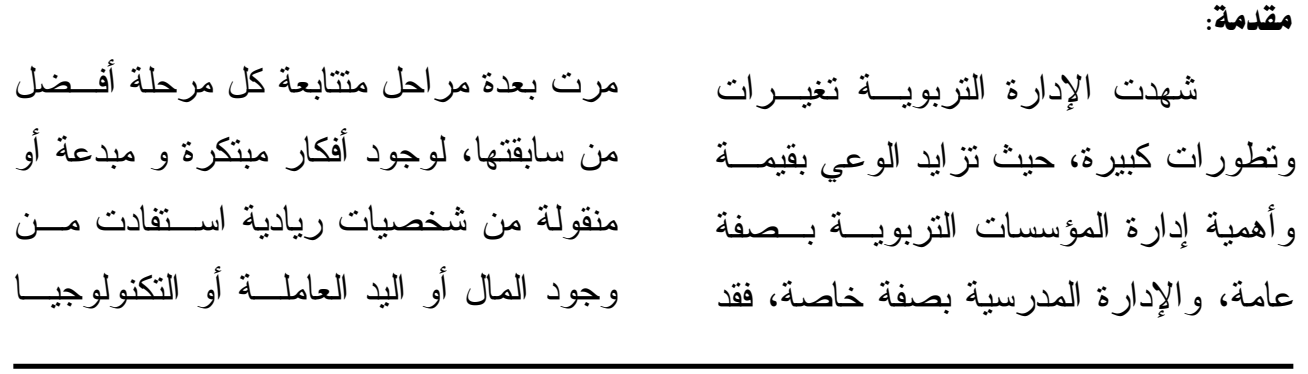


وبما أن الريادة من أبرز المتغيــرات

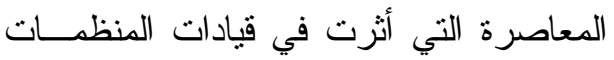
حيث اعتبرت أن المشاركة و التمكين و الثفافية و الحوكمة و العدالة التتظيمية مــن منطلبــات

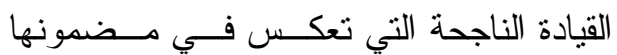
ديمقر اطية الإدارة، و التي قادت بدور ها إلـى لـى

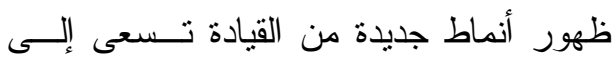

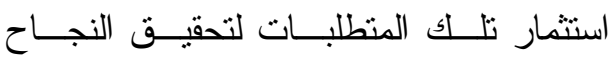

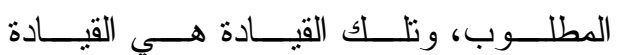

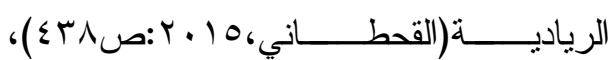
فالمنظمة الريادية هي التي تقوم على الإبــــاع الحقيقي والابتكار بالعمل على تفعيل موظفيها

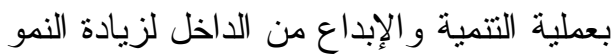

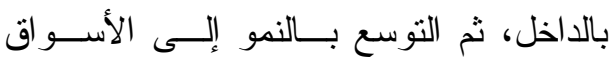

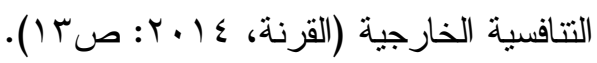
وفـي هــذا الـسياق تـشير الحيلــة

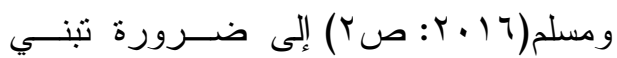
المنظمات المعاصرة اســنز اتيجيات مبدعــة، إلى فضلاً عن استقطاب إمكانات بـشرية قــادرة

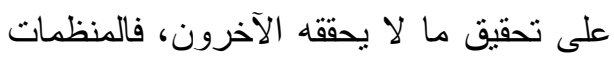

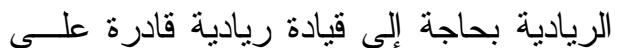

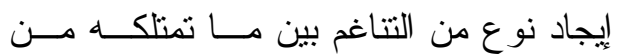

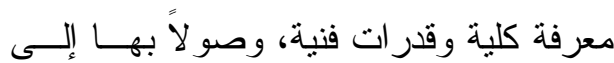
مركز تتافسي للولوج إلى عــالم المنظـــات

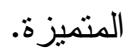
كما تعتبر الريادة سمة أساســية مــن سمات الاقت صـاديات المعاصــرة، فــالتطور
و انتهزت الفرص لتحسين الوضــع القـائم

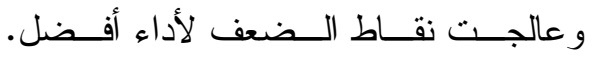
فالثخصية الريادية فـي أي مجــال مــن

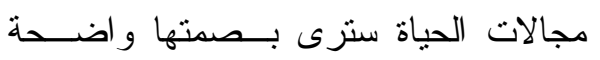
ومخطط لها، لنأخذ على ضرب المثال فكرة مشروع التحـــول فــي المملكـــة العربيـــة

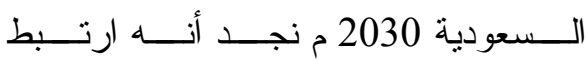
بالثخصية الريادية الثنابة صاحب الـسمو الملكي الأمير محمد بن سلمان ال ســعود.

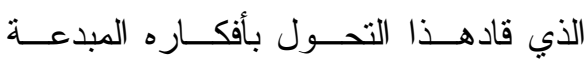
و المبتكرة وماز زال يذلل كافــة الــصعوبات

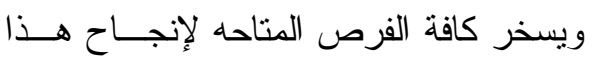
التحول،ونحن في عامنـــا الحــالي2019 م نطمح جميعا كمو اطنين لهذا البلا المعطـــاء

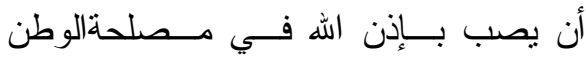
و المواطن وهذه بتوفيـق الله تعــالى ثــــا بمباركات سيدي خادم الحرمين الـشريفين أدام اله عز هم جميعا. فالريادة تعد ظاهرة من الظــــواهر

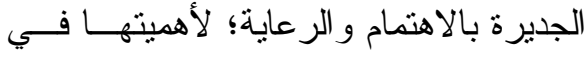
التتمية التي تسعى إليها مختلف المجتمعات،

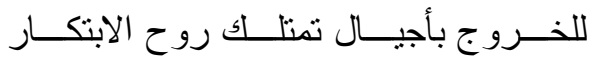
و الإبداع ، وتدرك الفرص وتبادر في تنبيها،

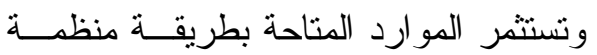

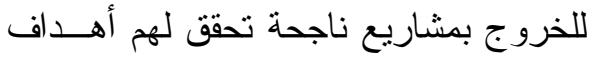

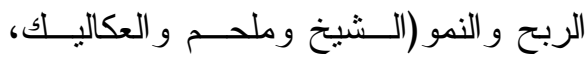

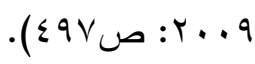


فالرياديين أشخاص بمثلكون ســمات

شخصية وسلوكية قد نكون فريدة كالقدرة على

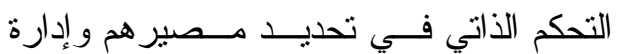

أنفسهم و الثقة بالنفس وتحمل المخاطرومرونة

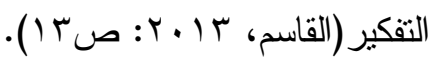

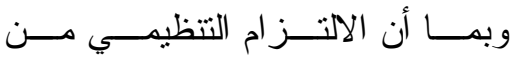

المتغيرات الحديثة التي لاقت اهتمام كبير من

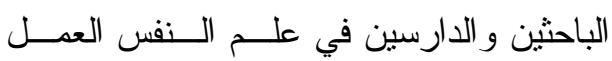

و التتظيم،فهو سلوك غير ملموس نابع من ذات

الفرد تلمسه في تصرفات العامل مــن حيـــث

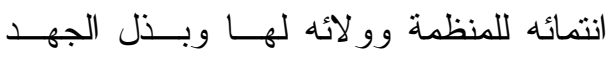
و الوقت لإنجاحها، و هذه الأهمية لها أثز كبير في المنظمات ونتائجها على مـسـتوى الفــرد

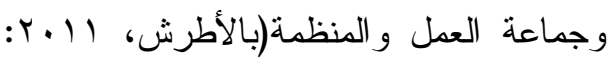
ص ب)،وذللك انطلاقاً مــن أهميتـــه ونتائجـــه

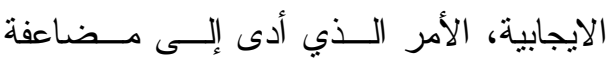
جهودهم في تحديد العوامل التي تــؤثز فـي تطويره وتعزيزه وترسيخه ضــمن الفلـسفة

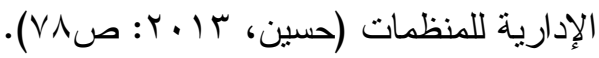

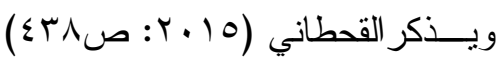

أن البيئة التتظيمية الــسريعة التغييــر وذات

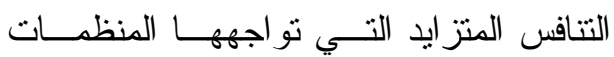
اليوم؛ تمثل أحد أبــرز المتغيــر ات العالميـــة المؤثزة في إدارة المنظمات، مما جعلها تحتاج إلى نوع من القادة المتميزين و المختلفين عـن

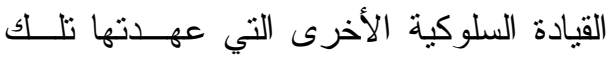
المنظمات، وتلاك هي القيادة الريادية.
التكنولوجي وتقــدم الاتــصالات وازديـــاد

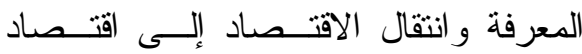
معرفي متز ابط ساهمت فـي ازديــاد دور الأفكار الريادية وتطلبت إثـــر الك الجميـعـع بتتوعهم الثقافي والحضاري لغرض تبنـي النجاح و التقدم على مختلف المستويات، ففي منظمات الأعمـــال تعتبــر الريــادة ســــة ضرورية لنجاح وتطــور هــذه الأعمــال

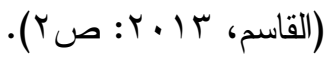
ويمنل تو افر الخــصائص الرياديــة

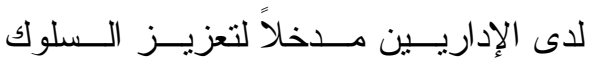
الريادي و على النحو الذي أفضى بالمنظمات

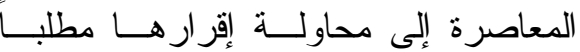

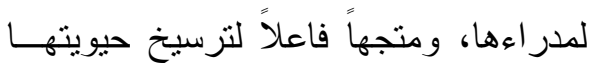
كونها تجسد جو انــب شخــصية، وتعكــس منطلقات سلوكية ذات مــديات اســـر اتيجية تؤشر حقيقة وواقعية الفعل الإنساني وقدرته

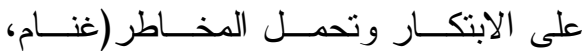
(r)

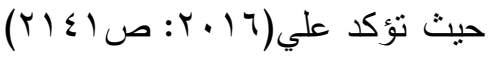
أن لخصائص الفرد وسماته الثخصية أثـر إيجابي في سلوكه وتوجيهاته و أدائه، ولعــلـل من أبرز هذه الخصائص نللك الخـصائص المتعلقة بالريادة وسلوكياتها، و التــي تـدفع الأفر اد بشكل عام و المدر اء بــشكل خـــاص إلى المثابرة وبذل الجهـــود لأداء الخدمـــة و الأفر اد بكفاءة وفاعلية وتحقيق الجودة فيه. 
ويتصف الأفر اد الذين لديهم التـز ام تتظيمــي

بالصفات التالية: قبول أهداف وقيم المنظمـــة الأساسية و الإيمان بها، وبذل المزيد من الجهد لتحقيق أهداف المنظمة، ووجود مستوى عال من الانخر اط في المنظمـــة لفتــرة طويلـــة، ووجود الميل لتقويم المنظمة الثقويم الإيجابي، ويتصف الالتزام الوظيفي بأنه متعدد الأبعـاد

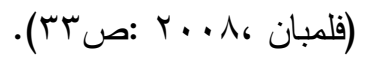

كما يعد تعزيــز الالتــزام التنظيمـي

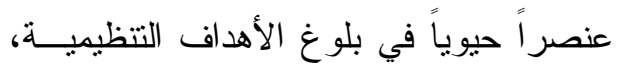
وتعزيــز الاســتقر ار و الثقـــة بــين الإدارة و العاملين فيها ويسهم فــي تطــــير قــدرات المنظمة على البقاء و الاستمر ار، لــــا كـــان هناك اهتمام من قبل الباحثين لما له من أهمية

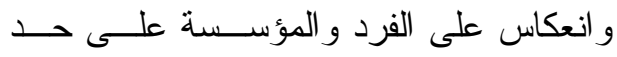
سو اء، كما يؤدي الالتز ام التنظيمي إلى عـدد

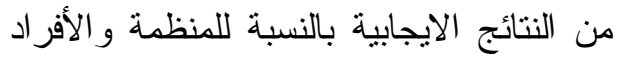
كانخفاض معــدل دوران العــل، وتحقيـق أهداف المنظمة بكفاءة وفعالية، وعلى الجانب الآخر فإن ضعفه يؤدي إلى ارتفــاع تكلفـــة

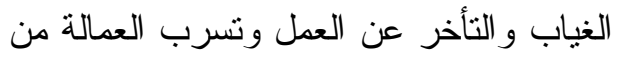

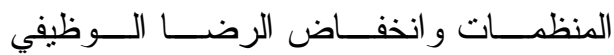
(عاشوري، 0 • ب: ص • (1). ولذلك تسعى المؤســسات التربويـــة

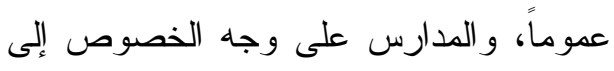
تجويد العملية التعليمية والارتقاء بالمسـتوى العلمي و التزبوي للطالب، وتقديمه كمخــرج
فوجــود المنـــاخ المناســب داخــل

المنظمة يسهم في تتمية وتطــــير المــوارد البشرية، لما له من دور حيوي في التـأثير على بعض المتغير ات الأخرى ذات الــصلة

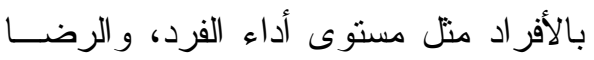
الوظيفي، و الالتز ام التنظيمي وغير ها مــن

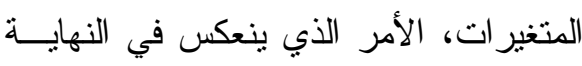

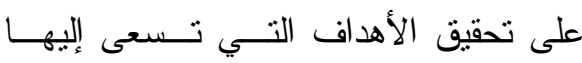
المنظمة(المغربي، V + . rاص • ( ). ويعد تعزيز الالتز ام التنظيمي لــدى

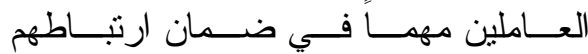
بالمنظمة، إذ تحاول المنظمة تتسيق جهـود

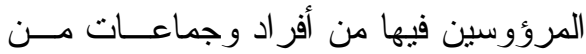

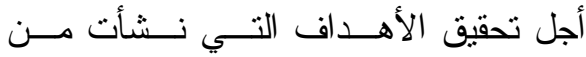

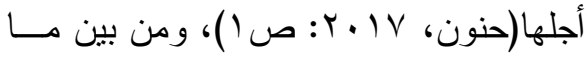
يتطلبه تحقيق ذللك غرس ثقافة الالتز ام لاى

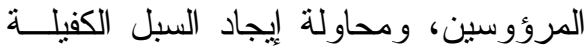
التي تؤمنها المنظمة للحصول على التــزام شامل للفرد حيال المنظمة لكنها تــدرك أن منل هذا الالتز ام قد يكـــون مــن الــصعب

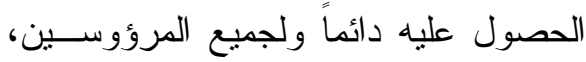
ولذلك فالمنظمة لا ترفض أن يكون إلز امــاً على مستوى معين منها بل ينبغي تـشـيعه

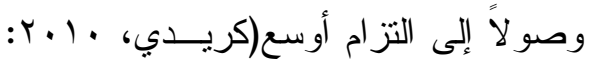

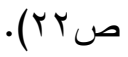
فالالتز ام التنظيمي يؤثر على قـــرار

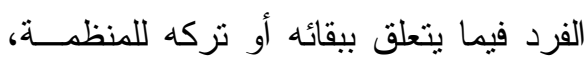




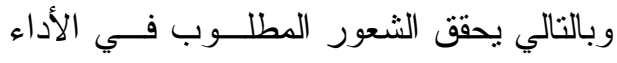

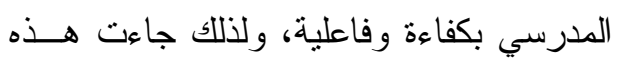

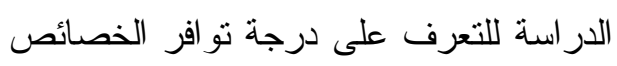

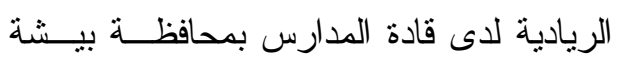

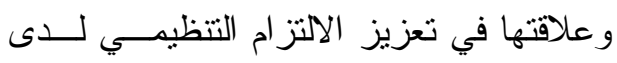
المعلمين من وجهة نظر هم.

مشكلة الدراسة وأسئلتها:

تو اجه منظمات اليوم ظروفــاً بيائيــة

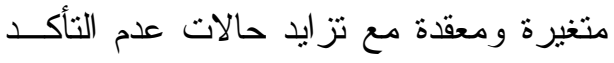

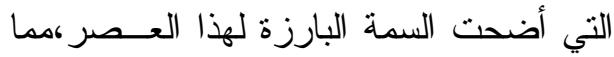
تطلب ضرورة امــتلاك المنظمــة طاقـات و إمكانات فائقة قادرة على مو اجهة العوامـلـل المؤثرة في أدائها، ولغرض الاستمر ار و النمو

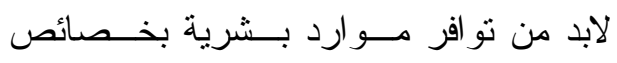

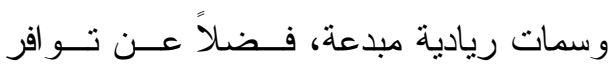

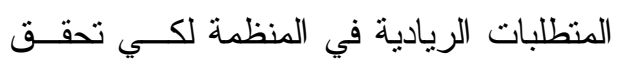
المنظمة أهدافها المنشودة وتستمر فــي دنيــا

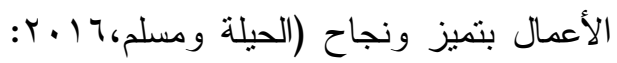

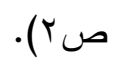

ومع ازدياد الاهتمام بدراسة موضوع

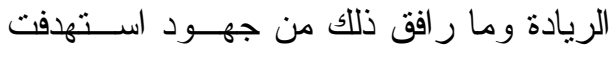
التعرف على مختلف الجو انب التتظيمية التـي من المككن أن تتأثز بها سواء على المستوى

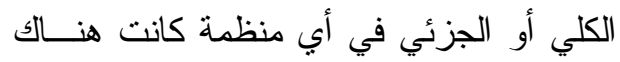

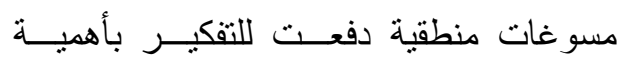
خصائص الثخص الريادي وفــي أي مجـــال

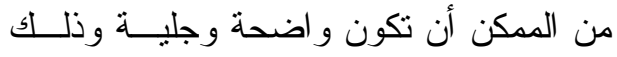

متميز من خلال اســتخدام مجموعــة مــن

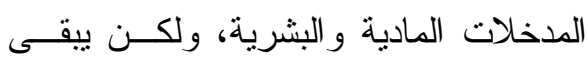
المعلم المحرك الأساسي لأداء ومعالجة ذلك وله كله حيث بيتوقـف مـستوى الأداء داخـلـل

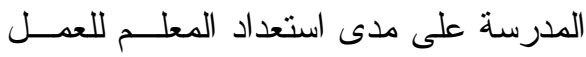
بروح المسؤولية، وبدرجة عالية من الالنزام

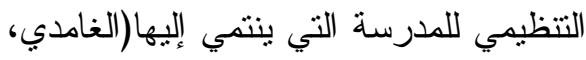

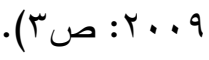
وبما أن الالتـز ام التنظيهـي مــن

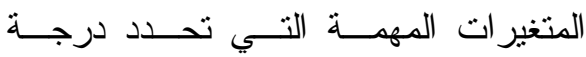

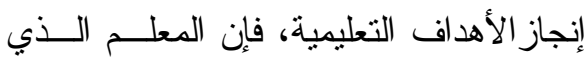
يثنعر بمستويات عالية من الرضا الـــوظيفي و الالتز ام التتظيمي للمؤسسة التي يعمل فيها

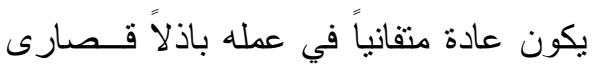

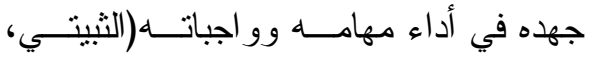
• (r) ولأن نشاط وكفاءة المعلم تزداد بزيادة الالتز ام التنظيمي، فإن قياس مستوى ولناء الالتز ام التتظيمي وتطوير العناصر الداخلية التي تؤثز على هذا الالتزام مهمة في تحسين أداء عملية التدريس حتى تشنمر وتتقلم في تأدية دور ها الاجتماعي ورسالتها

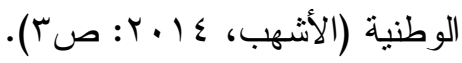
لذا يرى الباحث أن توفر عدد مــن

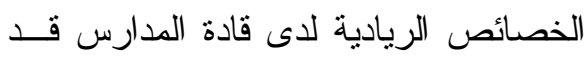
يكون له دور في تحقيق مستوى أعلى فــي لــي

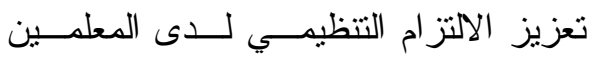




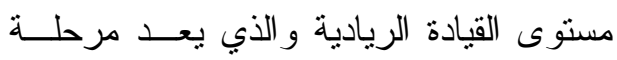
متقدمة من المر اتب القيادية، ويقع القادة الذين لا يدركون هذا التحدي في الــروتين الإداري

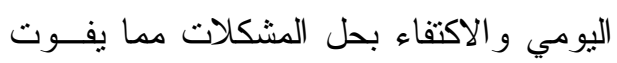

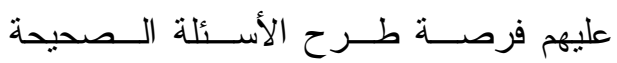
و التصور الذهني للعملية الإدارية التي تساعده

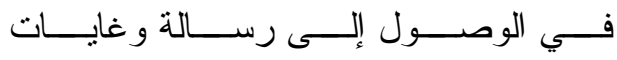

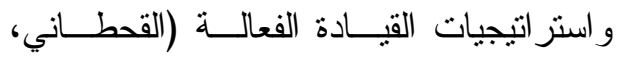

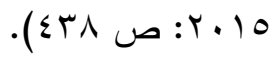

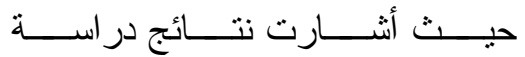

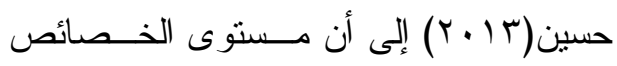

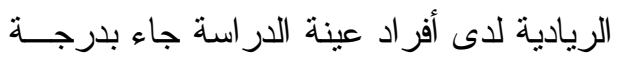

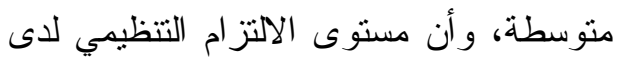

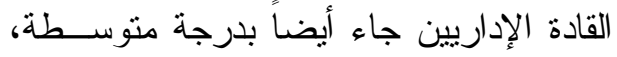
وضعف أثر الخصائص الريادية على الالنزام التتظيمي لدى عينة الدر اسة.

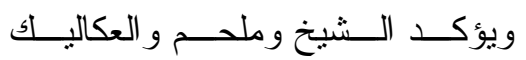

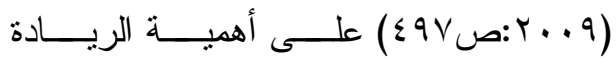
و الخصائص الريادية في منظمــات الأعمــال الركال كوسيلة لتحسن القدرة على اكتشاف واستغلال

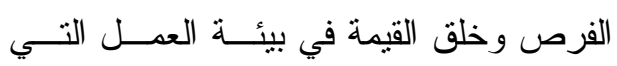
تتصف بالتعقيد الثديد و التغير المتسار ع. كما تعد الحاجة ملحـــة لوجـــود قائــــ

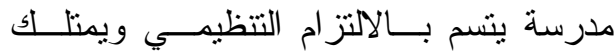

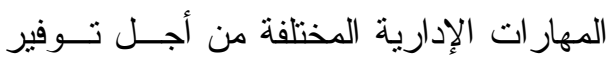

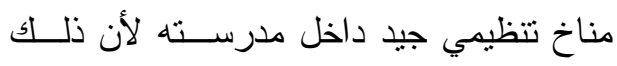

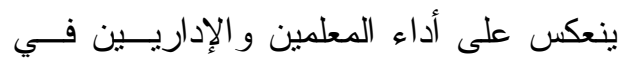

بقصد التركيز عليها وتعميق اسـتخداماتها

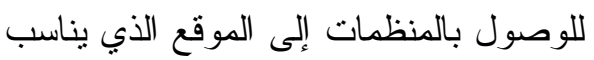

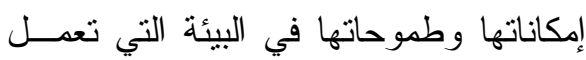

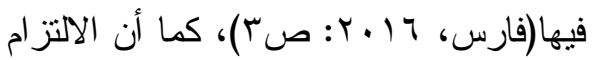
و المثابرة، وبذل الجهد المطلـــوب صــفات

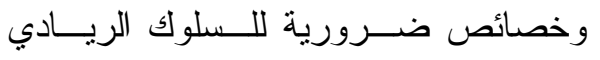

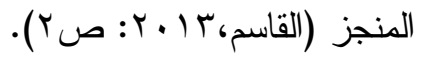
ولتحقيق الاستفادة المنلى من قدرات و إمكانات العاملين لا بد من الوصول إلـى لـى درجة عالية من الالتزام التتظيمي لديهم، إذ لإل أن غياب الالتزام التنظيمي له دور بارز في لهن تخفيض الفاعلية النتظيمية، ولقد تجـاوزت الدر اسات التي وظفت في البحث وتفـسير

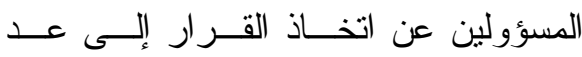

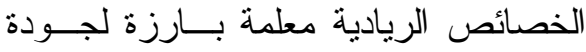
القرار و السلوك، ومتغير اً على درجة عالية من الأهمية بل و اعتبرتها القــوة الأساســية ولية التي تدعم الكثير من الأفعال الاســتراتيجية

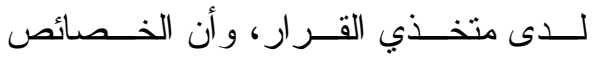
الريادية أصبحت تمثل حجر الأساس ونقطة انطلاق نحو الوعي بالأهداف، فهي تهيــئ قاعدة معرفية واستدلالية تجعل المعني فيها قادراً على التفاعل مع التطور ات و التحو لات

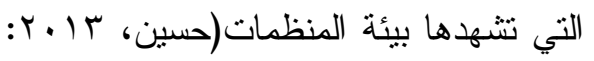
صن/7). من هنا يو اجه القادة الإداريون العديد

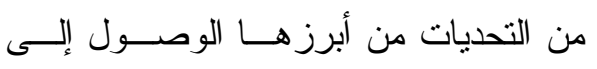


r- ما درجة تعزيز قادة المدارس للالتز ام

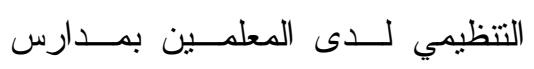

محافظة بيشة من وجهة نظر المعلمين؟

r- هل توجد علاقة ارتباطية ذات دلالـــة

(a

0.05 بين نو افر الخصائص الرياديـــة

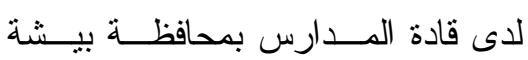

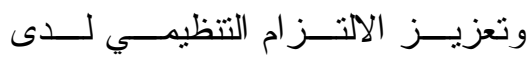

المعلمين؟

أهداف الدراسة:

تههف هذه الدراسة إلى الكثف عـن

درجة تو افر الخصائص الريادية لــدى قـــادة

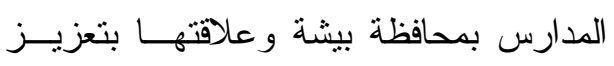

الالتز ام التتظيمي لدى المعلمين.

الدراسات السابقة:

المحور الأول: دراسات تتعلق بالخصائص الريادية

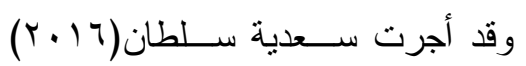

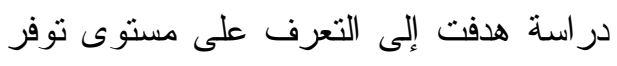

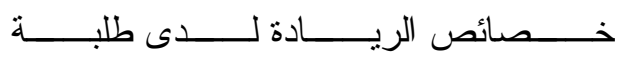

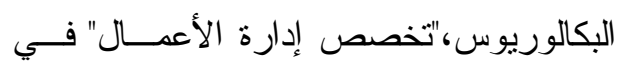

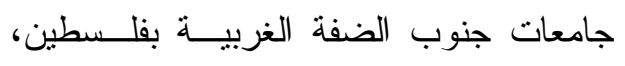

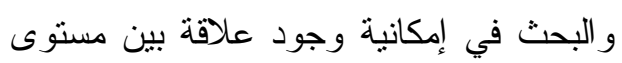

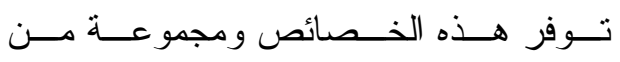

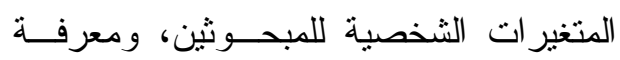
الاحتياجات اللازمة لدى الطلبة للتوجه للعمل

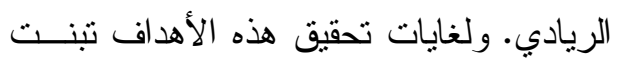

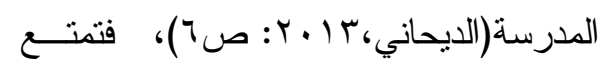

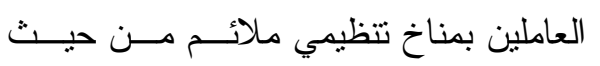

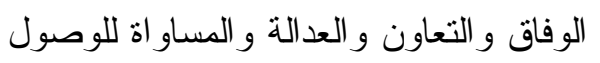

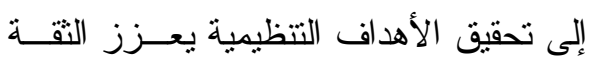

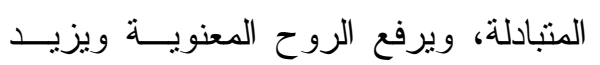

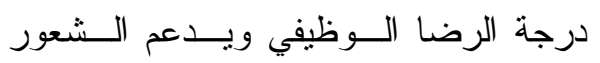

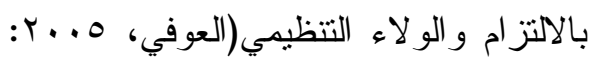

ص صوץ).

لذا أصبح العديد من قادة المــدارس

مسؤولين عن توجيه المؤسسات التعليميـــة

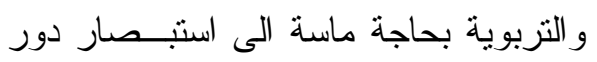
الخصائص الريادية في بناء وتعزيز الالنزام

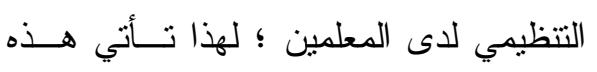
الدر اسة للكثف عن درجة نو افر الخصائص الريادية لدى قادة المدارس بمحافظة بيـشة درهة

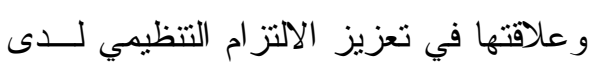
المعلمين.

و أكثر تحديداً تسعى الدراسة الحالية للإجابة عن السؤال الرئيس التالي: ما درجة

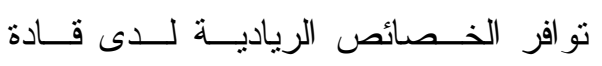

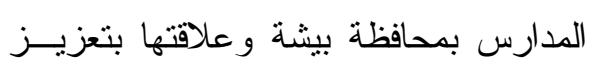

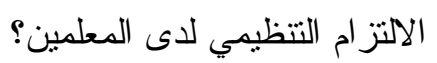
ويتفرع من هذا السؤال الرئيس الأسئلة الفرعية التالية:

1 - ما درجة تو افر الخصائص الرياديــة

لاى قادة المدارس في محافظة بيشة من وجهة نظر المعلمين؟ 


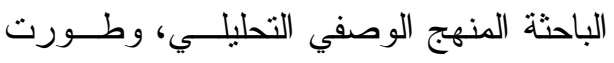

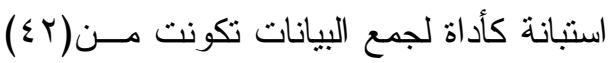

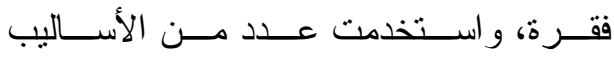
الإحصائية أبرز ها: المتوســـات الحسـسابية،

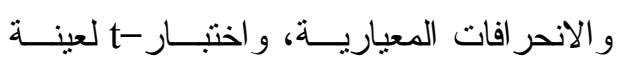
مستقلة، وتحليل الانحدار المتعدد، ونوصــلت ولته

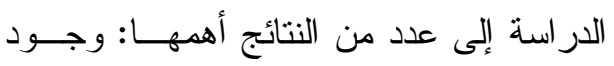

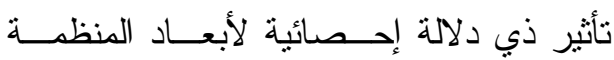

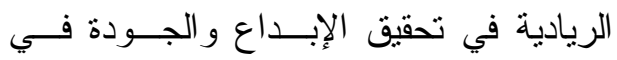
المشرو عات الصغيرة و المتوسطة في مدينــة عمان، ووجود نأثير ذي دلالة إحصائية لأبعاد المنظمة الريادية في تحقيق المرونة الهيكليــة و التميز في المشروعات الصغيرة و المتوسطة في مدينة عمان.

وقام أوكومينا (Okhomina , 2010)

بدر اسة هدفت هذه الدراسة إلى التعرف على دور مجموعة من العو امل المنمنلة بالـسمات

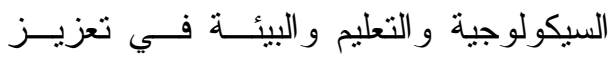
الموقف الريادي لدى الأفر اد كما بين مواقف

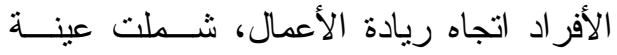

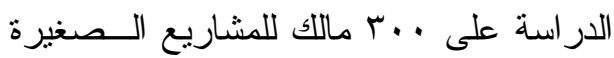
بحيث تم استخدام الاســنبانة كــأداة لجمـع البيانات. و أظهرت نتائج الدر اسة أن للسمات السيكولوجية دور إيجابي في التـأثثر علــى النى تعزيز المواقف الريادية للأفر اد، كما أظهرت النتائج أن عامل البيئة وعامل التعلـيم تــؤئز

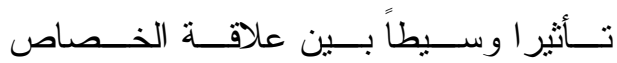

الدر اسة المنهج الوصفي التحليلي، وقد تكون

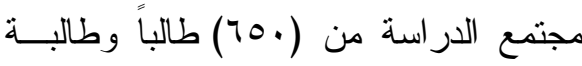
موزعين على جامعات الضفة الغربية، وتم

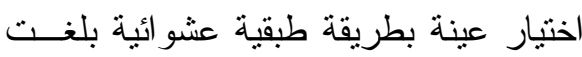

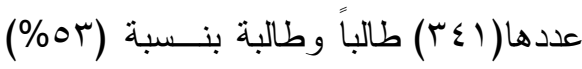

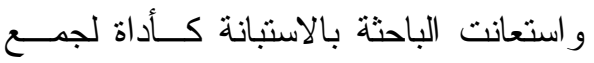
البيانات. وقد توصلت الدر اسة إلى عدد من لبن النتائج أهمها: أن مستوى توفر خـصـائص

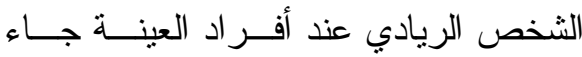

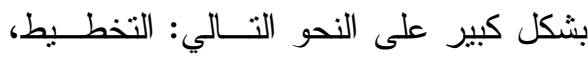

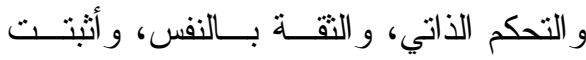
الدر اسة عدم وجود فروق في درجة تـــوفر

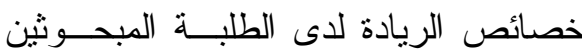
تعزى إلى متغير الجنس، و المعدل الجامعي،

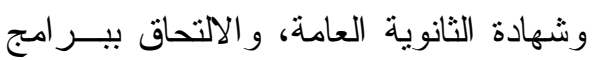

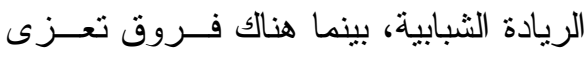

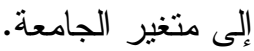

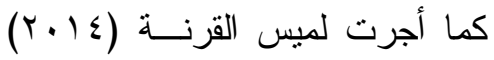
دراسة هدفت إلى قياس وتحليل أثز أبعـاد المنظمة الرياديـــة فــي تحقبــق التتافـسية المـستـدامة فــي المــشروعات الــــيرة و المتوسطة، وقد تكون مجتمع الدراسة من

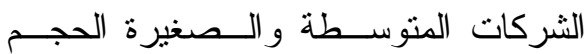

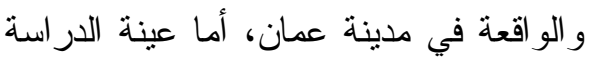
فقد كانت عينة ملائمة من العـاملين البــالغ

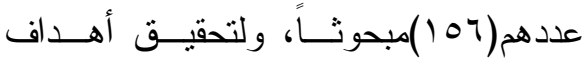

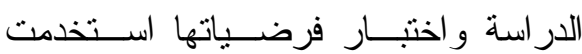


التزبية و التعليم الأردنية فـي إقلــيم الوســط

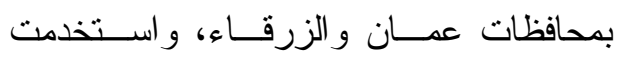
الباحثة المنهج الوصفي التحليلي، وقد تكــون

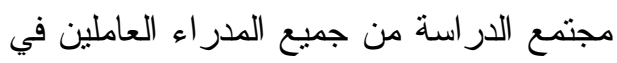
مديريات التربية و التعليم الأردنية فــي إقلــيم

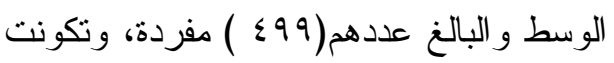
عينة الدر سة من (TYT) مديراً في مديريات

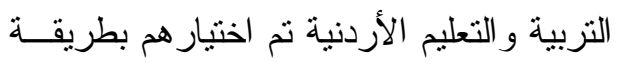

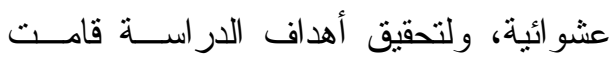
الباحثة بإعداد استبانة وتوزيعها على المدر اء اهنه العاملين فــي مــديريات التربيــة و التعلــيم الأردنية،وللإجابة عن أسئلة الدراسة واختبار

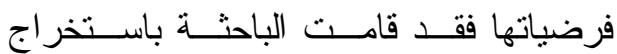

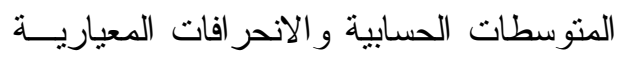
وتطبيق معادلة الانحدار المتعدد، وتوصــلت الدراسة إلى النتائج التالية: هنالك أثر ذو دلالئة

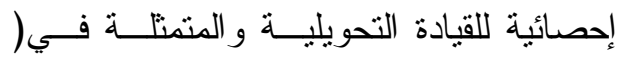
التأثير المثالي، التحفيز الإلهامي، الاســنتارة

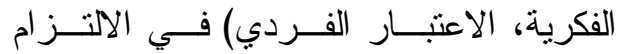

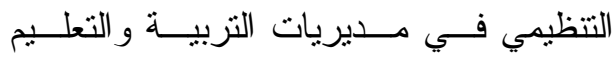
الأردنية في إقليم الوسط. كما تبين عدم وجود فروق في آراء المدراء حول القيادة التحويلية على الالتزام التنظيمي في مديريات التربيــة

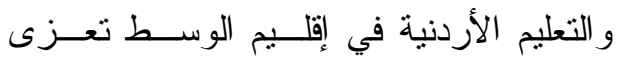

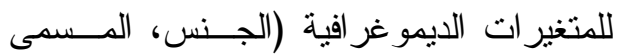
الوظيفي، العمر، المستوى التعليمي، ســنوات

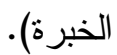

السيكولوجية و المو اقف الريادية للأفر اد. وقام أهايرسكي و تونانين'( , 1999 (Hyrsky and tuunanen إلى قياس دور السمات المتمتلة بالقدرة على بلى

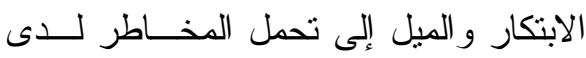
رواد الأعمال ومالكي المشاريع الــــيرة الــيرة في كل من فنلندا و الو لايات المتحدة في دعم

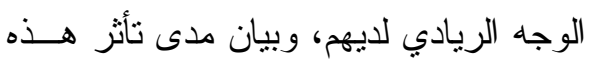
السمات بالمتغيرات الديمغر افية، كما هدفت

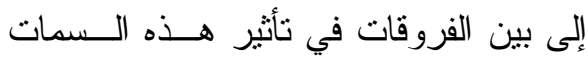
لاى كل من الذكور و الإناث. وشملت عينة الار اسة على 07؛ ماللك مشروع وريــادي من الولايات المتحدة و ع بـ من فنلندا بحيث استخدمت الاستبانة كأداة لجمـــع البيانــات. و أظهرت نتائج الدراسة ان لهذين الـسمتان دور بالغ في الوجه الريادي لأفــر اد، كمــــا

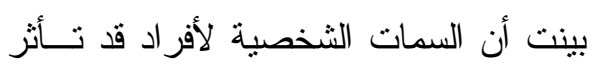

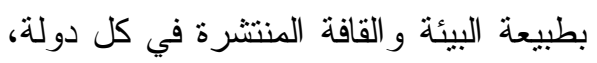
كما أظهرت أن عامل القدرة على الابتكــار

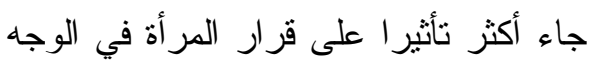

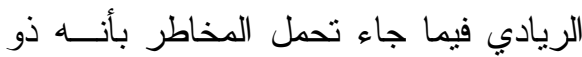
نأبر أعلى لدى الرجل. المحور الثاني: دراسات تتعلــق بــالالتز ام

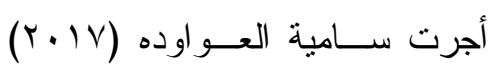
دراسة هدفت إلى التعرف على أثز القبــادة التحويلية في الالتز ام التتظيمي في مديريات 
وقام أيــدين و أخــرون ( Aydin, et

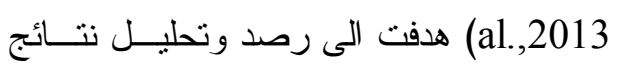

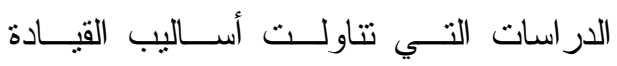

بالمؤسسات التعليمية، و التي تتاولــت تـأثنير

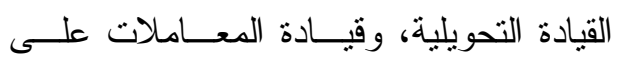

الرضا الوظيفي و الالتز ام التتظيمي للمعلمــين

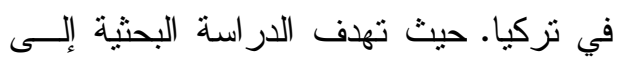

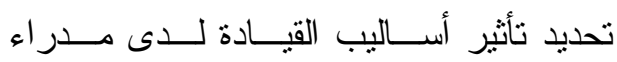

المدارس على الرضــــا الــــــيفي و الالتــز ام

التتظيمي للمعلمين باستخدام طريقة التحليـلـل

التجميعي، تم تحليل اثتي عشر بحثا في تركيا بالنيا

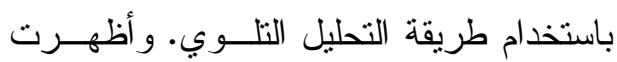
نتائج البحث أن أسلوب القيادة التحويلية بشكل خاص أثز على الرضـا الـــــــيفي والالتــز ام

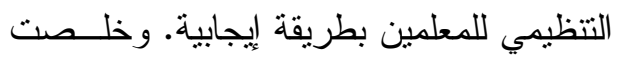
الدراسة إلى أن أسلوب القيــادة فـــي الإدارة

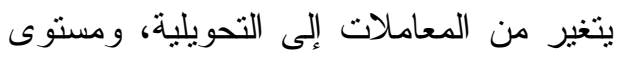
الرضا الوظيفي والالتز ام التتظيمي للمعلمـين ارتفع.

وأجرى غين (Ghina, 2012) در اسة

هدفت إلى التعرف على تأثثر ثقافة الثركات

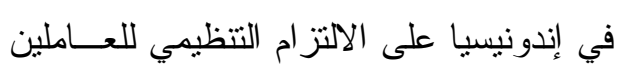

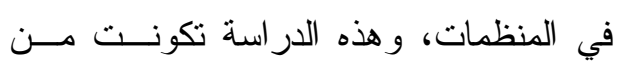

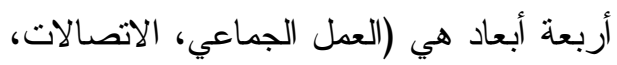

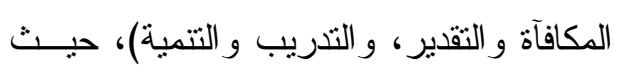

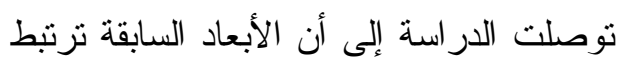

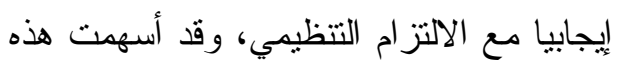

وأجرى الأشهب (ع ا.ب) دراســة

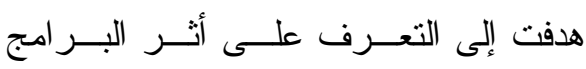
التذريبية في الالتز ام التنظيمي لدى المعلمين

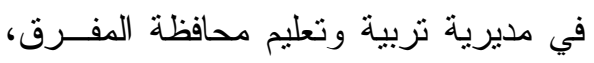

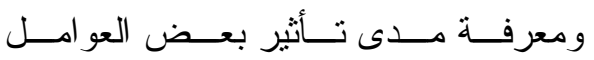

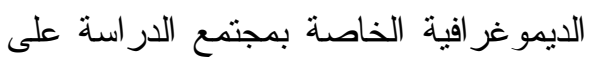

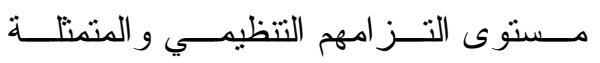
في(الجنس، العمر، المستوى التعليمي، عدد

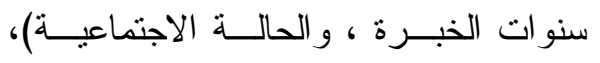
واستخدم الباحث المنهج الوصفي، وقد نكون مجتمع الدراســة مــن جميـع المعلمــين و المعلمات في المدارس الحكومية التابعــة لمديرية تربية وتعليم محافظة المفرق و البالغ

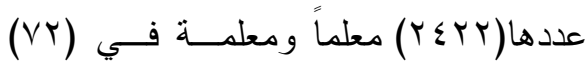
مدرسة، وتكونت عينة الدراسة من (ro0) معلماً ومعلمة نم اختيار هم بطريقة عشو ائية، ونكونة

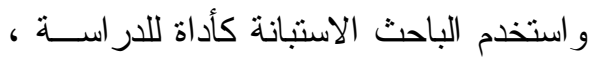
وتوصلت الدر اسة إلى عدد من النتائج مــن أهمها: أن درجة مستوى الالتز ام التتظيمـي مئي

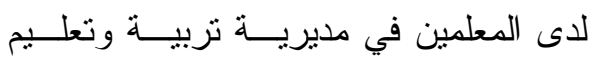

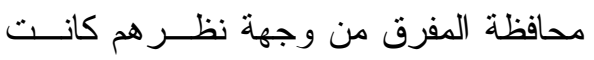

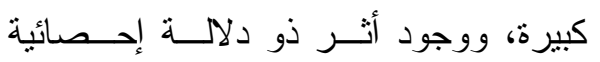
للبرنامج التدريبي في الالتز ام التتظيمي لدى دود دله

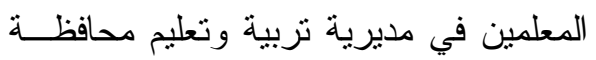

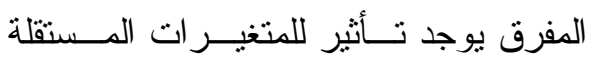
مجتمعة على المتغير التابع. 
الالتز ام التتظيمي لاى عينة من متخذي القرار

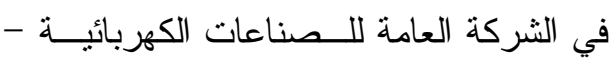
محافظة ديالى، وقد تم تنبني المنهج التحليلــي

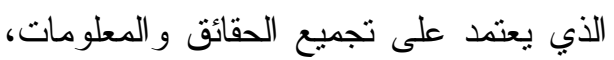

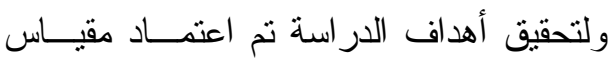

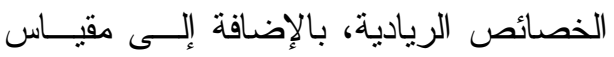
الالتز ام التتظيمي، وطبقت الدراسة على عينة

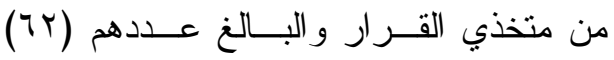
مفردة، تــم اختيــار هم بطريقــة عـشـوائية،

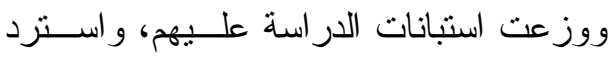

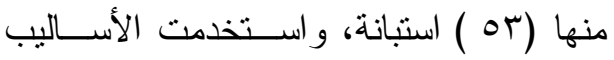
الإحصائية المناسبة للإجابة عن أسئلة لدر اسة الدة

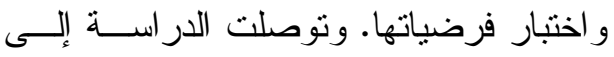

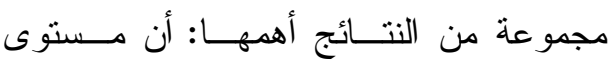

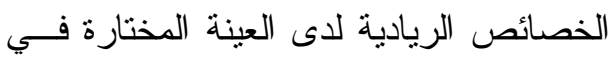

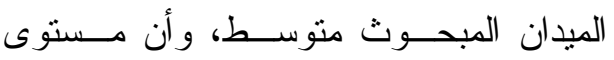
الالتز ام التظظيمي لدى القادة الإداريـيـين فــي وني الميدان المبحوث متوســــ وضـــف أثــر للخصائص الريادية على الالتــز ام التتظيـــي وصي

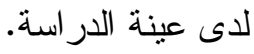

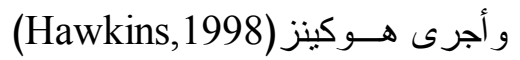

در اسة هدفت إلى تحديد العلاقة بين خصائص هولهر

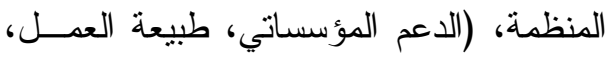

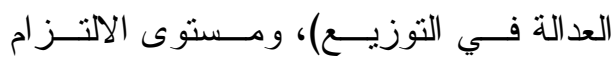

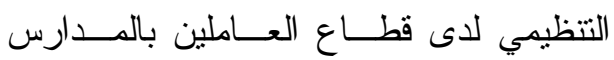

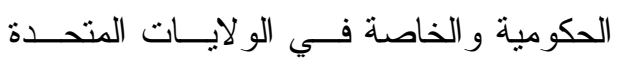
الأمريكية. كما هدفت إلى تحديد العلاقة بـين ولين
الدر اسة في فهم أفضل لتأثير ثقافة الثركات

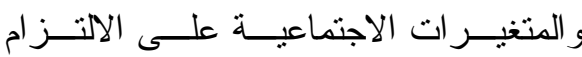

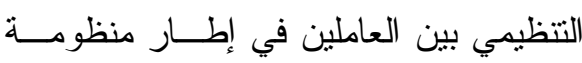

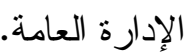

و هدفت در اســـة هوليبـــا وأخــرون (Hulpia, et al., 2009)

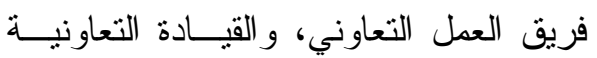
و القيادة الموزعة، و المشتاركة فــي اتخــاذ القرار على الالنز ام التنظيمي للمعلمين فـي

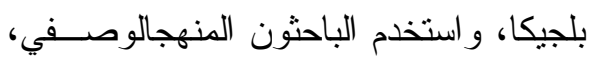
وتكون مجتمع الدراسة من معلمي المرحلة

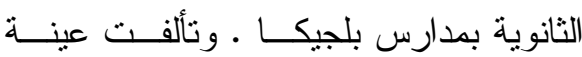

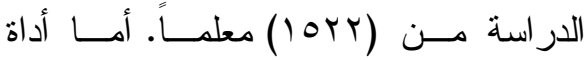
الدر اسة فقد استخدم الباحثون مقياس ماوداي

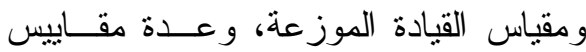

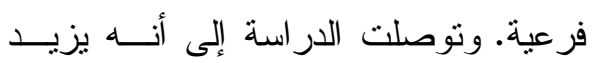
الالتز ام التنظيمي للمعلمين في المدارس التي

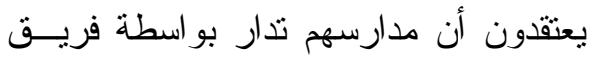
متعاون، و أيضاً المدارس التـي يـشـاركون فيها في صنع القرار، وكثفت النتائج أيضاً أن المعلمين الأكثر خبرة أقل النزاماً تتظيمياً من المعلمين الأقل خبرة. المحور الثالث: دراسات تناولت العلاقة بين الخـــصائص الرياديـــة وتعزيــز الالتـــز ام أجرى حسين(ب ( • Y) در اسة هدفت إلى الكثف عن أثز الخصائص الريادية في 
التتظيمي، ومدة الخدمة و الجنس لدى العاملين

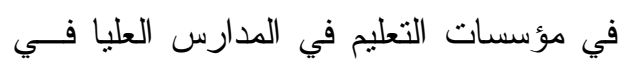
الو لايات المتحدة الأمريكية.

منهج الدراسة وإجراياتها

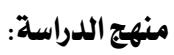

استخدم الباحث في هذا البحث المنهج

الوصفي الارنباطي لملائمته لأهداف الدراسة لإنة

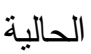

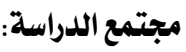

تكون مجتمع الدر اسة من جميع معلمي

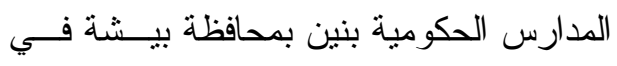

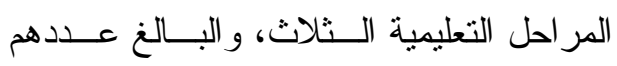

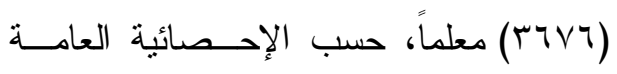

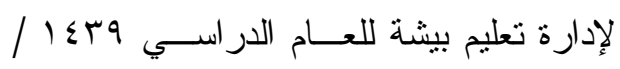
.
المتغير ات الثخــصية ومـسـتوى الالتــز ام التتظيمي لدى العاملين في قطــاع التعلــيم بأمريكا. واستخدم البحث المنهج الوصــفي لوني وقد أجريت الدراسة على عينة مكونة مسن ونـ

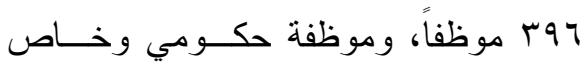

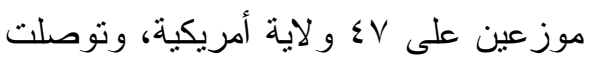

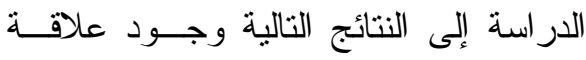
إيجابية بين كـلـ مــن مـستوى الالتــز ام التنظيمي وخصائص المنظمة المنمنلة فــي لئني التوزيع، و الدعم المؤسساتي، فالمؤسـسـات وحسئ

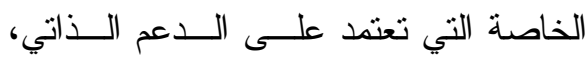
ويكون فيها عدالة في توزيع الحوافز يكون

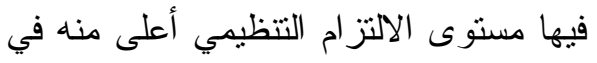

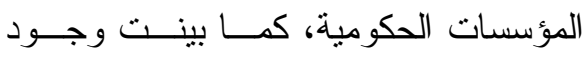
علاقة بين السن ومستوى الالتز ام التتظيمي، و عدم وجود علاقة بين مسستوى الالتـز ام جدول ( 1) توزيع مجتمع الاراسة على مكاتب التعليم و المراحل التعليمة

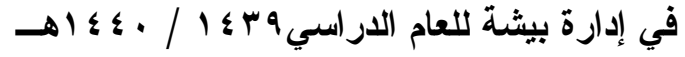

\begin{tabular}{|c|c|c|c|c|c|c|c|}
\hline \multirow{2}{*}{ المئوية } & \multirow{2}{*}{ الاجمالي } & \multicolumn{5}{|c|}{ مكاتب التعليم } & \multirow{2}{*}{ التعليمة } \\
\hline & & خيير & بتبرج & الثية & النقيع & الوسط & \\
\hline $49.5 \%$ & 1821 & 115 & 173 & 285 & 174 & 1074 & ابتدائي \\
\hline $19.7 \%$ & 723 & 58 & 72 & 86 & 62 & 445 & منوسط \\
\hline $30.8 \%$ & 1132 & 65 & 445 & 88 & 84 & 450 & ثانوي \\
\hline \multirow[t]{2}{*}{$100 \%$} & 3676 & 238 & 690 & 459 & 320 & 1969 & المجموع \\
\hline & $\% 1 \ldots$, & $\% \uparrow, 0$ & $\overline{\% \backslash \wedge, \wedge}$ & $\% \backslash r, 0$ & $\overline{\% \wedge, \vee}$ & $\% \circ r, 4$ & النسبة المئوية \\
\hline
\end{tabular}
وذلك حسب إحصائيات إدارة التعلــيم فـي

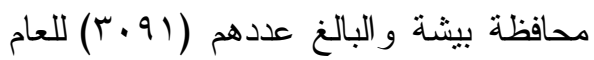

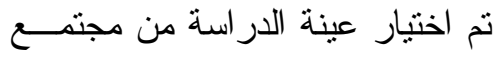

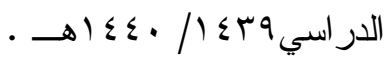

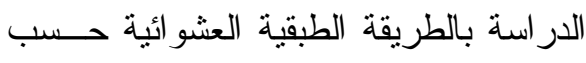

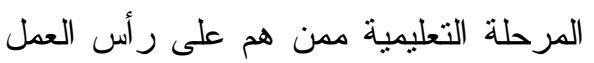


جدول (r) خصائص أفر اد عينة البحث

\begin{tabular}{|c|c|c|c|}
\hline النسبة & 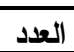 & الفئات & المتغيز \\
\hline $50.3 \%$ & 176 & ابتدائي & \multirow{4}{*}{ المرحلة التعليمية } \\
\hline $19.7 \%$ & 69 & متوسط & \\
\hline $30.0 \%$ & 105 & ثانوي & \\
\hline $100.0 \%$ & 350 & المجموع & \\
\hline $37.1 \%$ & 130 & أقل من خمس دور ات تدرييية & \multirow{3}{*}{ الدور ات الترريية } \\
\hline $62.9 \%$ & 220 & خمس دور ات تدرييية فأكثر & \\
\hline $100.0 \%$ & 350 & المجموع & \\
\hline $40.0 \%$ & 140 & أقل من عشر سنو ات & \multirow{3}{*}{ سنو ات الخبرة } \\
\hline $60.0 \%$ & 210 & عشر سنو ات فأكثر & \\
\hline $100.0 \%$ & 350 & المجموع & \\
\hline $12.6 \%$ & 44 & مكتب الثثية & \multirow{6}{*}{ ككتب التعليم التابعة له المدرسة } \\
\hline $6.6 \%$ & 23 & مكتب خيير & \\
\hline $9.1 \%$ & 32 & مكتب النقيع & \\
\hline $53.4 \%$ & 187 & مكتب الوسط & \\
\hline $18.3 \%$ & 64 & مكتب ترج & \\
\hline $100.0 \%$ & 350 & المجموع & \\
\hline
\end{tabular}

يتضح من الجدول (2) أن أكثر من التابعة لها المدرسة فقد جاء في المقدمة مكتب

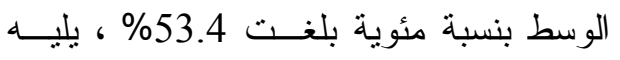

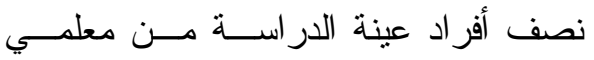

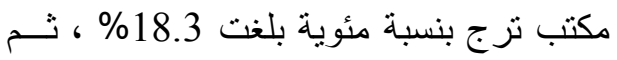

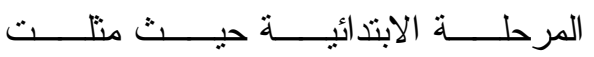
مكتب الثثية بنسبة مئوية بلغت 12.6\%، يليه

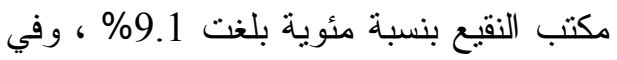

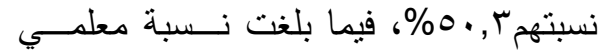
المرتبة الاخيرة مكتب خيير بنـسبة مئويسـة

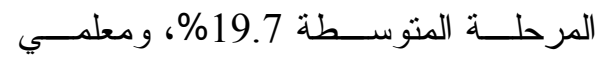

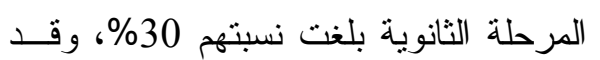

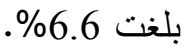
تبين ان ما نسبته 62.9\% من افر اد عينـــة

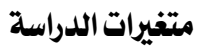

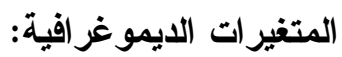

المرحلة التعليمية، ولها ثلاث مستويات:

$$
\text { (ابتدائي، منوسط، ثانوي). }
$$

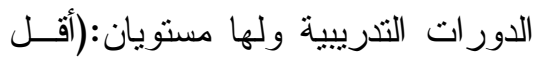

$$
\text { من } 0 \text { دور ات، } 0 \text { دور ات فأكثر) ). }
$$

سنو ات الخبرة، وله مسنويان:(أقل مــن دورن

• ( سنو ات، · سنو ات فأكثر).

مكتب التعليم التابعة له المدرسة وله هن اله
البحث حصلو ا على اكثر من خمس دورات

تدريبية، فيمـا حـصلت النسبة الباقيــة

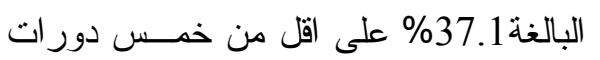

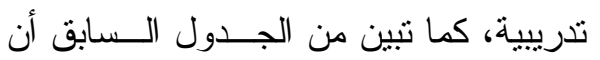

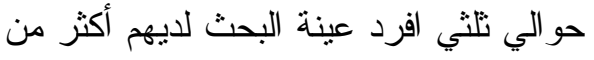

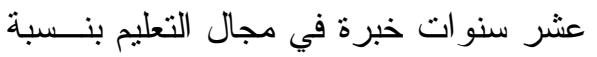

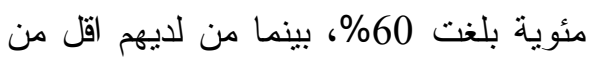

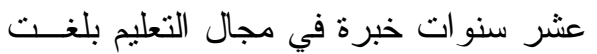
نسبتهم 40\%، وفيما يتعلق بمكاتب التعلــيم 
المخاطرة ويتكون من(V) فقر ات ، و المجــال

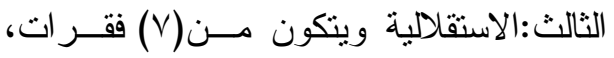

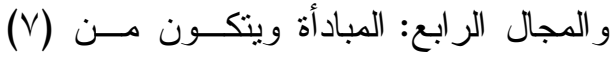

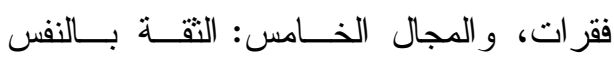

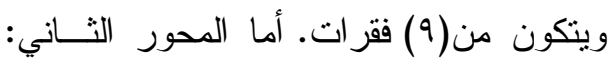
تعزيز الالتز ام التتظيمي لاى المعلمين يحتوي على (•؛) فقرة موزعة على ثلاثة مجالات،

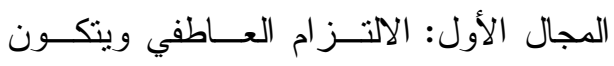

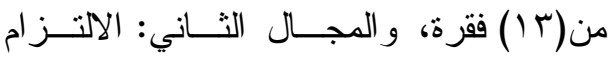
المستمر ويتكون من(بال) فقـرة، و المجــال

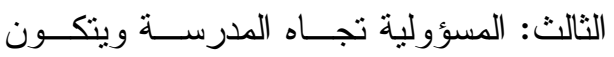

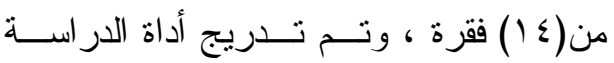
تدريجا خماسيا حسب مقياس ليكرت الخماسي

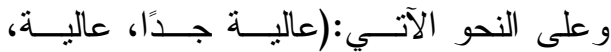
منوسطة، منخفضة، منخفضة جدًا).

\section{صدق أداة الدراسة}

تم التحقق من صـــدق أداة الدراســـة

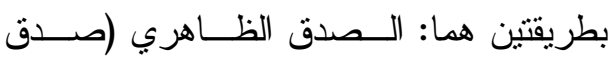

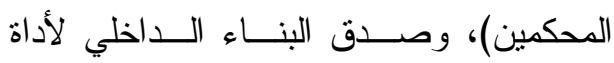
الدر اسة . الدمين ، الصدق الظاهري (صدق المحكمين) تم التحقق من الصدق الظـــاهري لأداة

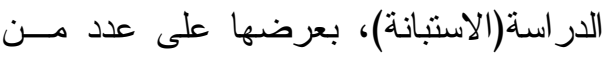
المحكمين المتخصصين فـي مجــال الإدارة

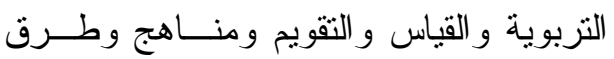
التدريس في جامعة الباحة صدق البناء الداخلي لأداة الدراسة لكة

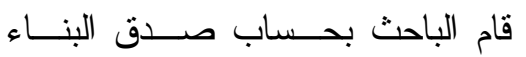
الداخلي لاداة الدر اسة وذللك باستخدام طريقـــة

$$
\begin{aligned}
& \text { فئات :(مكتب الثثيــة،ككتب خييــر ، مكتــبـ } \\
& \text { النقيع، مكتب الوسط، مكتب نزج ) . } \\
& \text { المتغير المستقل: }
\end{aligned}
$$

درجة تو افر الخصائص الريادية لاى

قادة المدارس بمحافظة بيشة.

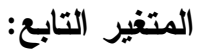

درجة تعزيــز الالتــز ام التتظيمـي

للمعلمين بمحافظة بيشة.

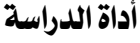

قام الباحث بتصميم استبانة لتحقيق

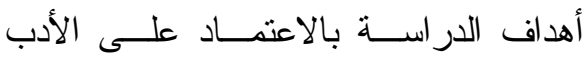

النظري، و الدراسات السابقة ذات العلاقـــة بموضوع الدراسة، وســتنكون الأداة مــن

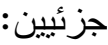

الجزء الأول: ويتضمن المتغيــرات

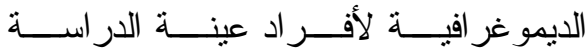

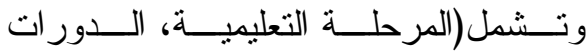

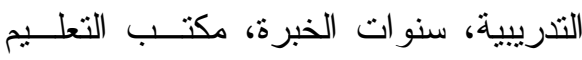
التابعة له المدرسة).

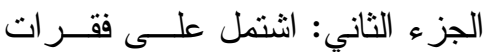
درجة تو افر الخصائص الريادية لدى قــادة

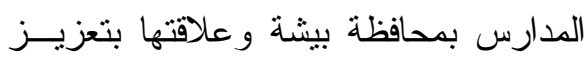
الالتز ام التتظيمي لاى المعلمين، حيث فــام

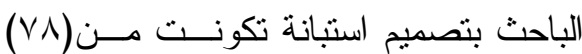
فقرة موزعة على محوريين المحور الأول:

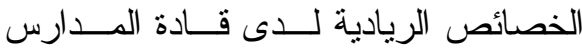

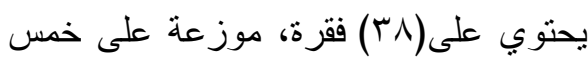

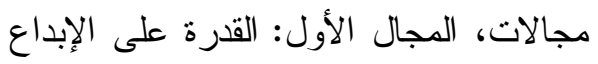

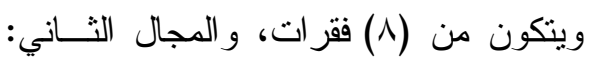


أ - صدق البناء الداخلي لفقــرات مجــالات

$$
\text { الاستبانة مع الارجة الكلية لكل مجال. }
$$

تم حساب دعاملات الارتباط بين كـلــل

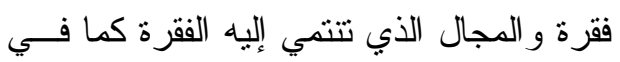

$$
\text { الجدول(3): - ال }
$$

الصدق البنائي، و التي تعتمد علــى حـساب أنساب معامل الارتباط بين كل فقرة من فقرات أداة

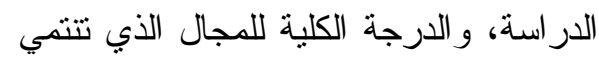

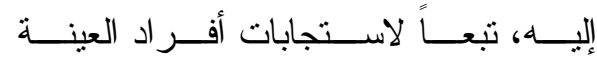

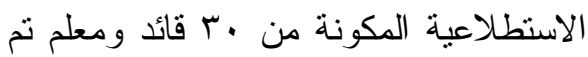
إستبعادهم من العينة الرئيسة لهذه الدر اسة.

\begin{tabular}{|c|c|c|c|c|c|c|c|c|c|}
\hline & & إبرس & 1 & ص الرياد & (S) & & & & \\
\hline س : الثقّة & المجال & ع: المبادأة & المجال & الالثالية: & & خاطرة: الثاني: & & على الإبداع: & القطر \\
\hline $.764 * *$ & $r$ & $590 * *$ & 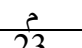 & $683 * *$ & $\vec{r}$ & $\frac{\jmath}{658^{* *}}$ & $\begin{array}{l}b \\
0\end{array}$ & $603 * *$ & \\
\hline $.625^{* *}$ & 31 & $769^{* *}$ & $\frac{25}{24}$ & $634^{* *}$ & $\frac{17}{17}$ & $666^{* * *}$ & 10 & $668^{* * *}$ & $\frac{1}{2}$ \\
\hline $.816^{* *}$ & 32 & $752 * *$ & 25 & $.676^{* *}$ & 18 & $696^{* *}$ & 11 & $799 * *$ & 3 \\
\hline $.808^{* *}$ & 33 & $.646^{* *}$ & 26 & $.698^{* *}$ & 19 & $.792 * *$ & 12 & $.754 * *$ & 4 \\
\hline $.646^{* *}$ & 34 & $653 * *$ & 27 & $715 * *$ & 20 & $.593^{* *}$ & 13 & $.754 * *$ & 5 \\
\hline $.719^{* *}$ & 35 & $753 * *$ & 28 & $.694 * *$ & 21 & $.624 * *$ & 14 & $.698^{* *}$ & 6 \\
\hline $.725^{* *}$ & 36 & $693 * *$ & 29 & $.754 * *$ & 22 & $695^{* *}$ & 15 & $.738^{* *}$ & 7 \\
\hline $.799^{* *}$ & 37 & & & & & & & $.783^{* *}$ & 8 \\
\hline $.712 * *$ & 38 & & & & & & & & \\
\hline
\end{tabular}

جدول (3) معامل ارتباط بيرسون (Pearson) بين الفقرة والمحور التي تنتمي إليه

\begin{tabular}{|c|c|c|c|c|c|}
\hline \multicolumn{2}{|c|}{ المجال الثَالث: المسؤولية تجاه المدرسة } & \multicolumn{2}{|c|}{ المجال آلثانى: الالتزام المستمر } & \multicolumn{2}{|c|}{ المجال الأول: الالتزام العاطفى } \\
\hline$\jmath$ & s & $\jmath$ & 5 & ر & s \\
\hline $.391 * *$ & 27 & $.360 * *$ & 14 & $.692 * *$ & r \\
\hline $.613 * *$ & 28 & $.595 * *$ & 15 & $.611 * *$ & 2 \\
\hline $.593 * *$ & 29 & $.555 * *$ & 16 & $.579 * *$ & 3 \\
\hline $.566^{* *}$ & 30 & $.569 * *$ & 17 & $.630 * *$ & 4 \\
\hline $.623 * *$ & 31 & $.677 * *$ & 18 & $.765^{* *}$ & 5 \\
\hline $.613 * *$ & 32 & $.578^{* *}$ & 19 & $.747 * *$ & 6 \\
\hline $.615 * *$ & 33 & $.628 * *$ & 20 & $.755^{* *}$ & 7 \\
\hline $.662 * *$ & 34 & $.644 * *$ & 21 & $.737 * *$ & 8 \\
\hline $.589 * *$ & 35 & $.698^{* *}$ & 22 & $.678^{* *}$ & 9 \\
\hline $.460 * *$ & 36 & $.676^{* *}$ & 23 & $.683^{* *}$ & 10 \\
\hline $.525 * *$ & 37 & $.627 * *$ & 24 & $.682 * *$ & 11 \\
\hline $.574 * *$ & 38 & $.572 * *$ & 25 & $.665^{* *}$ & 12 \\
\hline $.616^{* *}$ & 39 & $.657 * *$ & 26 & $.736 * *$ & 13 \\
\hline $.790 * *$ & 40 & & & & \\
\hline
\end{tabular}

المحور الثاني: تعزيز الاتتزام التظظيمي لاى المعلمين *** دال إحصائياً عند مسنوى الدلالة (1 ., ).

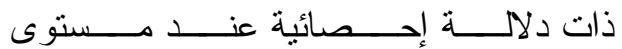
يتضح من الجدول (r) أن جميع قيم الدلالة( ( , ·)، ففيما يتعلق بــالمحور الأول:

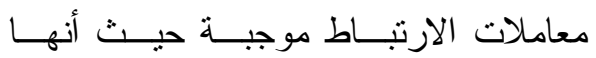
الخصائص الرياديــة لــدى قــادة المــــارس تز اوحت بين (0.816 - 0.360) وجميعهــا هونس

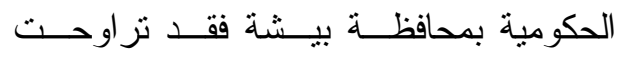


تز اوحت لمجال الالنز ام المـستمر مــا بـين (0.698 - 0.360)، ولمجال المسؤولية تجاه

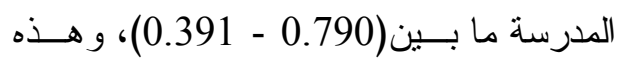
النتيجة نشير إلى صــــ الاتـساق الــــاخلي

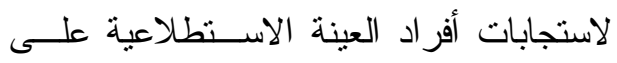
الأداة ، و أن الفقرات ذات علات علاقة ارتباطيه دالة إحصائياً بالمجال الذي نتتمي إليه

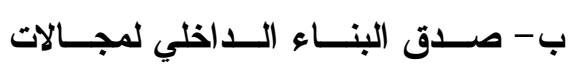
الاستبانة مع الدرجة الكلية للمحور:

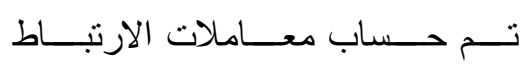

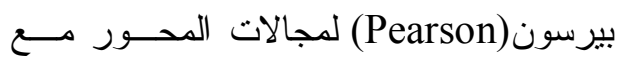
الدرجة الكلية للمحور تبعاً لاستجابات أفــر اد اد الدات العينة كما في الجدول (ع) : معاملات الارتباط بين الفقــرات و الدرجـــة الكلية للمجال الأول و الذي يقيس القدرة على لألى

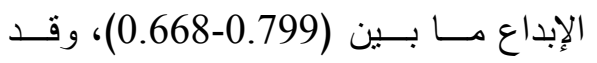
تراوحت لمجال المخاطرة ما بين ( - 0.593 0.792 0.792)، ولمجال الاستقلالية ما بين 0.754

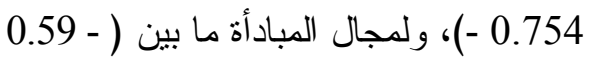
0.769)، أما مجال الثقة بالنفس مـــا بــين

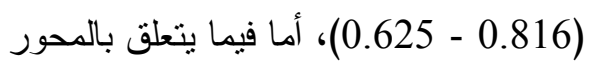

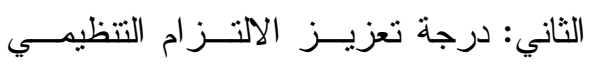

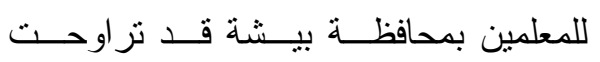

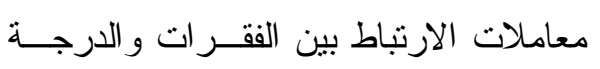

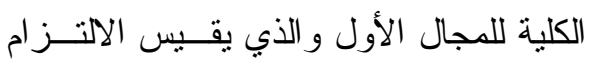

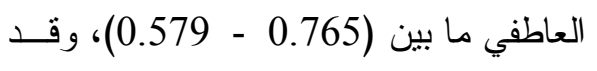
جدول (4) معامل ارتباط بيرسون (Pearson) بين المجال والدرجة الكلية للمحور الأي ينتمي له المجال

\begin{tabular}{|c|c|c|c|}
\hline \multicolumn{4}{|c|}{ المحور الأول الخصائص الريادية لاى قادة المدارس } \\
\hline معامل بيرسون & 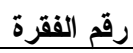 & عدد الفقرت & المحاور \\
\hline $.898^{* *}$ & $1-8$ & 8 & المجال الأول: القدرة على الإبداع \\
\hline $.934^{* *}$ & $9-15$ & 7 & المجال الثاني: المخاطرة \\
\hline $.917^{* *}$ & $16-22$ & 7 & المجال الثالث: الاستقلالية \\
\hline $.863^{* *}$ & $23-29$ & 7 & المجال الر ابع: المبادأة \\
\hline $.924^{* *}$ & $30-38$ & 9 & المجال الخامس: النقة بالنفس \\
\hline \multicolumn{4}{|c|}{ المحور الثاني: تعزيز الالنز ام التتظيمي } \\
\hline $.876^{* *}$ & $1-13$ & 13 & المجال الأول: الالتز ام العاطفى \\
\hline $.836^{* *}$ & $14-26$ & 13 & المجال الثاني: الالتز ام الدستمر \\
\hline $.874^{* *}$ & $27-40$ & 14 & المجال الثالث: المسؤولية تجاه المدرسة \\
\hline
\end{tabular}
دالة إحصائيًا عند مـستوى الدالامــة(0.01)، يتـــح مــن الجــدول(4) أن قــيم

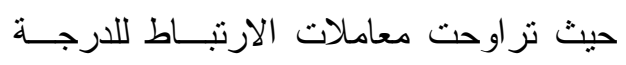
الكلية للمحور الأول: الخصائص الريادية لدى الدى لأن

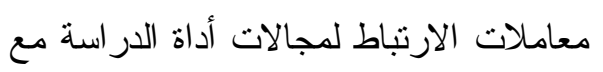

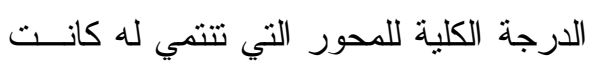


0.876)، حيث بلغ معامل الارتبـــاط لمجــال

الالتز ام العاطفي (0.876) ، (0.876)، ولمجال الالتــزام

المستمر (0.836) ، ولمجال المسؤولية تجــاه

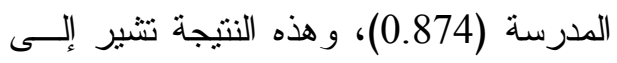

صدق الاتساق الداخلي لاستجابات أفر اد العينة

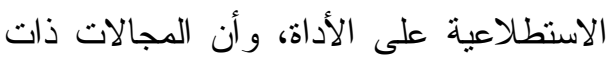

علاقة ارتباطيه دالة إحصائياً بالمحور الــذي الآني

تنتمي إليه.

ثبات اداة الدراسة :

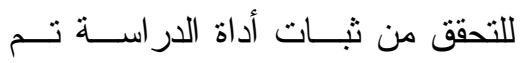

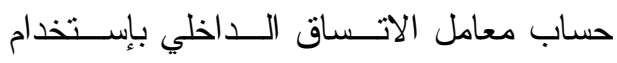

معادلة كرونباخ ألفـاتـات (Cronbach's alpha) للتأكد من ثبات الاتساق الداخلي لها بالإعتماد

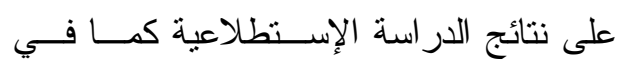

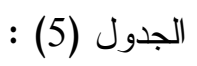

قادة المدارس الحكوميــة بمحافظــة بيـشة

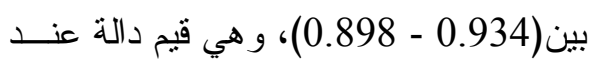

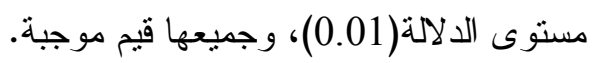

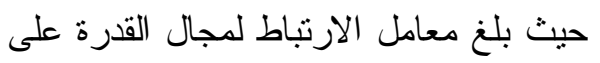

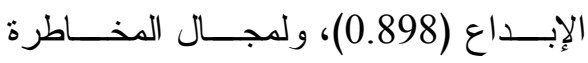

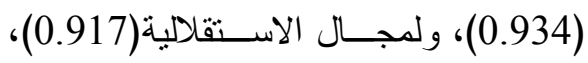
ولمجال المبـادأة(0.863)،ولولمجــال الثقـــة بالنفس (0.924) وجميعها قيم موجبة. كما بلاحظ أن أعلى ارتباط كسـان بــين مجــال

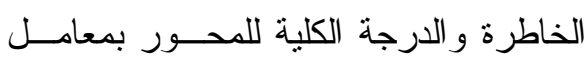

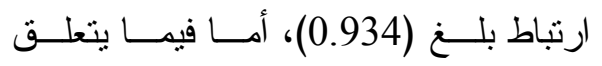

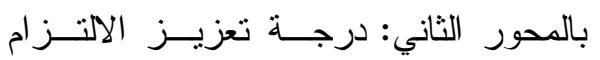

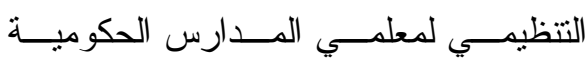

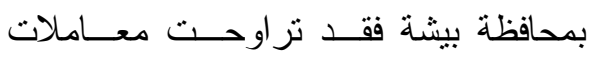
الارتباط للارجة الكلية للمحسور ( - 0.836

جدول (ه) معامل كرونباخ ألفا (Cronbach's alpha) للتأكد من ثبات اداة الدراسة

\begin{tabular}{|c|c|c|c|c|}
\hline معامل ألفا كرونباخ & رقفرة & الفقرات & 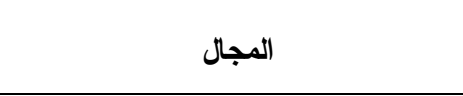 & م \\
\hline 0.877 & $1-8$ & 8 & المجال الأول: القدرة على الإبداع & 1 \\
\hline 0.799 & $9-15$ & 7 & المجال الثاني: المخاطرة & 2 \\
\hline 0.820 & $16-22$ & 7 & المجال الثالث: الاستقلالية & 3 \\
\hline 0.822 & $23-29$ & 7 & المجال الر ابع: المبادأة & 4 \\
\hline 0.892 & $30-38$ & 9 & المجال الخامس: النقة بالنفس & 5 \\
\hline 0.962 & $1-57$ & 57 & \multicolumn{2}{|c|}{ الدحور الأول الخصائص الريادية لاى قادة الدارس } \\
\hline 0.908 & $1-13$ & 13 & المجال الأول: الالتز ام العاطفي & 1 \\
\hline 0.900 & $14-26$ & 13 & لـالمجال الثانى: الالتز ام المستمر ـــ & 2 \\
\hline 0.907 & $27-40$ & 14 & المجال الثالث: المسؤولية تجاه المدرسة & 3 \\
\hline 0.965 & 58- 97 & 40 & \multicolumn{2}{|c|}{ المحور الثانى: تعزيز الالتز ام التتظيمى } \\
\hline
\end{tabular}




\section{تشير نتائج الجدول(0)إلى أن أداة إجراعات تطبيق أداة الدراسة}

تم اتخاذ الإجـــر اءات اللازمـــة لتطبيــق

در استه الميدانية على النحو الاتي : الإن

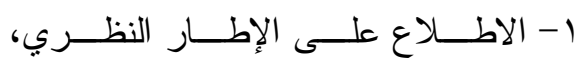

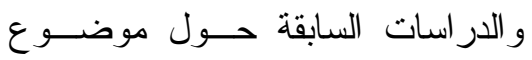

الدر اسة.

ץ- بناء أداة الدر اسة وهي الاستبانة لجمــع

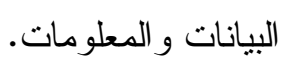

ب- الحصول على خطاب إفادة مــن كليــة

التزبية - جامعة الباحة للجهـات ذات

العلاقة بموضوع البحث (تعليم محافظة

$$
\text { بيشة). }
$$

ع - تم تطبيق أداة الدراســـة علــى عينـــة

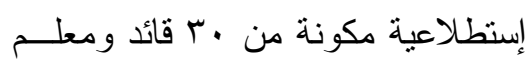

لحساب صدق وثنات الاداة

צ- جمع البيانات و المعلومات مــن أفـــر اد

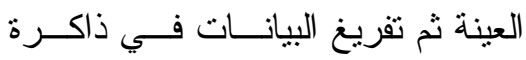

$$
\text { الحاسوب. }
$$

V - تحليـلـ البيانــات باســتخدام الرزمـــة

$$
\text { الإحصائية للعلوم الاجتماعية(SPSS). }
$$

ᄉ- تقديم نتــائج الدر اســـة وفـق أســــلتها

$$
\text { و أهدافها. }
$$

نتائج الدراسة ومناقشتها وتفسيرها

نتائج السؤال الأول ومناقشته وتفسيره:

مادرجة تو افر الخصائص الريادية

لاى قادة المدارس في محافظة بيشة من وجهة
الدراسة تتمتع بدرجة ثبات مرتفعة، فقد

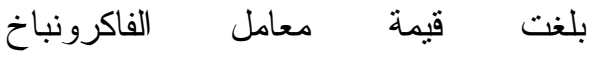
(Cronbach's alpha) المحور الأول الخصائص الريادية لدى قادة المدارس الحكومية بمحافظة بيشة(0.962)، كما نز اوحت قيمة معامل ألفا لمجالات المحور الاول (0.799 - 0.892)، فقد بلغ (Cronbach's معامل ألفا كرونباخ لاول لمجال القدرة على الإبداع alpha) (0.877)، ولمجال المخاطرة (0.799)، ولمجال الاستقلالية (0.820)، ولمجال المبادأة (0.822)، ولمجال التقة بالنفس ولمس (0.892) ، وقد بلغت قيمة معامل (Cronbach's alpha) الفاكرونباخ للمحور الثاني:تعزيز الالنزام التنظيمي لمعلمي المدر اس الحكومية بمحافظة بيشة (0.965)، كما تراوحت قيمة معامل ألفا لمجالات المحور الثاني (0.908 - 0.900)؛ فقد بلغ معامل ألفا كرونباخ (Cronbach's)

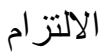

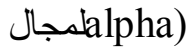

العاطفي(0.908)،ولمجال الالتز ام المستمر

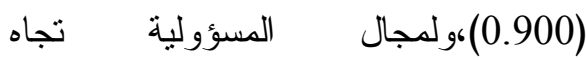
المدرسة(0.907)،وجميعها قليم مرتفعة للثبات، مما يدل على أن الأداة تتمتع بدرجة كبيرة جداً من الثبات ويمكن الوثوق في لأني نتائجها. 
نظر المعلمين؟ ولإجابة على هذا السؤال تم عن كل مجال من المجالات وعلى الاستبانة

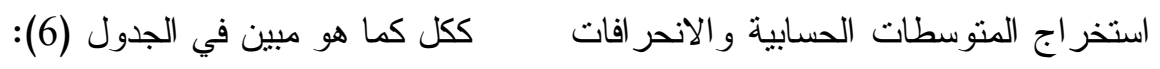

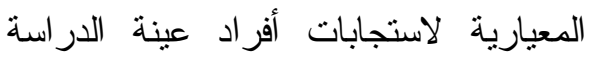
جدول (6) المتوسطات الحسابية والاتحر افات المعيارية لاستجابات أفراد عينة الدراسة على كل مجال من مجالاتها وعلى الاستبانة ككل مرتبة تنازليا حسب المتوسطات الحسابية لاسنية

\begin{tabular}{|c|c|c|c|c|c|c|}
\hline | الممارسة & الترتيب & الإحر اف المياري & الحستوسط & ن & 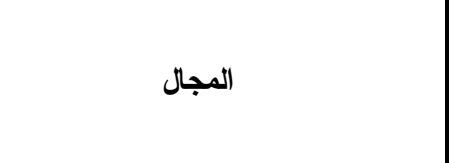 & الاسجال في \\
\hline عالية & 1 & 0.825 & 3.97 & 350 & المجال الأول: القدرة على الإبداع & 1 \\
\hline عالية & 2 & 0.804 & 3.91 & 350 & المجال الخامس: الثقة بالنفس & 5 \\
\hline عالية & 3 & 0.852 & 3.86 & 350 & المجال الر ابع: المبادأة & 4 \\
\hline عالية & 4 & 0.810 & 3.83 & 350 & المجال الثالث: الاستقلالية & 3 \\
\hline عالية & 5 & 0.889 & 3.83 & 350 & المجال الثاني: المخاطرة & 2 \\
\hline عالية & & 0.773 & 3.88 & 350 & الريادية لدى الكلية لمحور تو افر الخصائص مدارس محافظة بيشة & \\
\hline
\end{tabular}

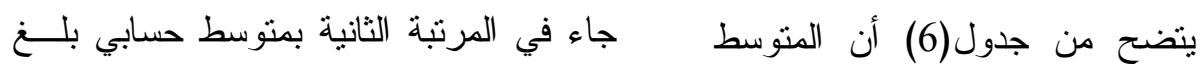

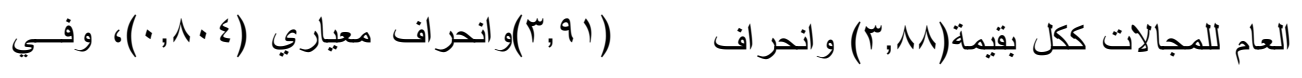

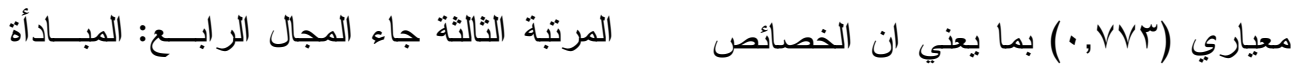

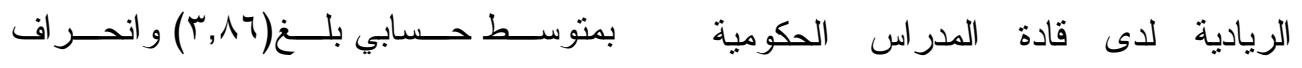

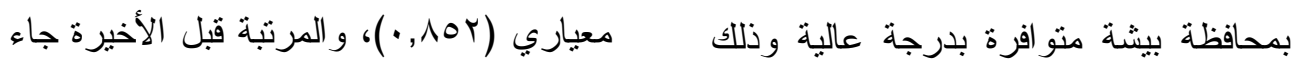

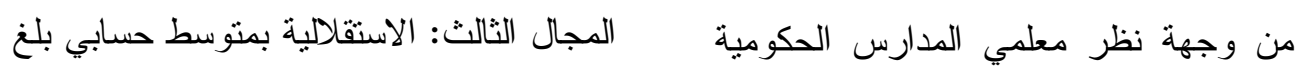

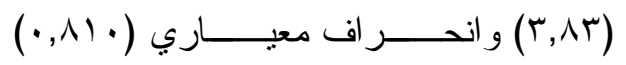
بمحافظة بيشة.

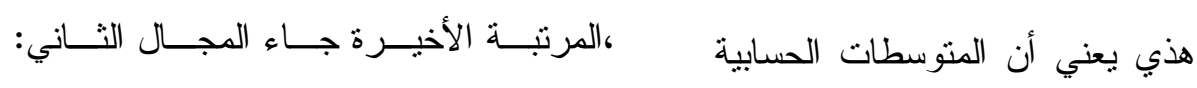

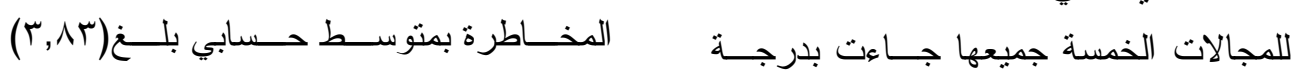

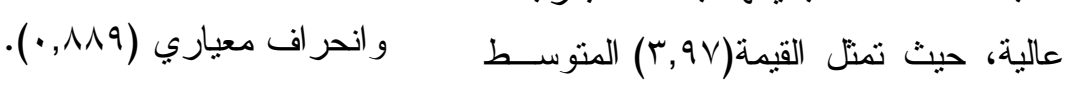
ويعزو الباحسـث هـــهـ النتيجــة الــى

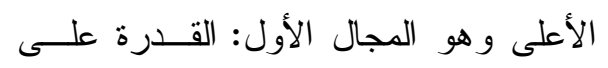

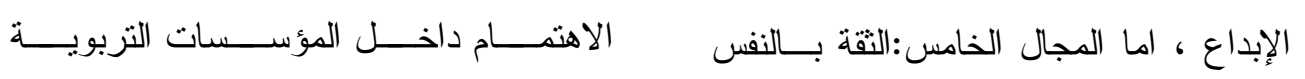


و المخاطرة في المر اتب الأخيرة فهذا لايعنـي أنها غير موجودة ولكنها في الواقـــع تحتـــاج خبرات وكذلك أنظمة وزارة التعليم المركزية

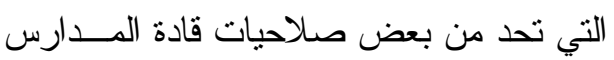
مما يجعلها أكثر تقيدا بالأنظمة المدرسية التي تحددها الوز ارة ومكاتب التعليم.

وتتفق هذه النتائج مع دراسة ســعدية

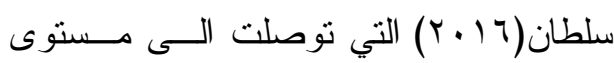

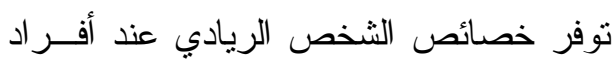

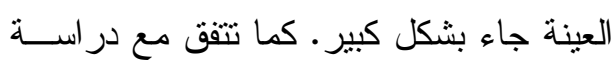

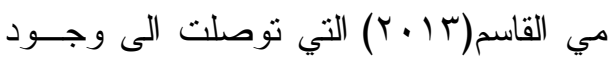
أثز ذي دلالة إحصائية للخصائص الرياديــة،

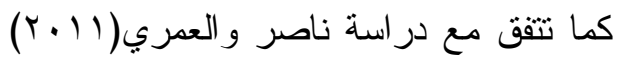

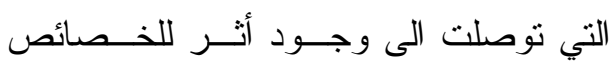

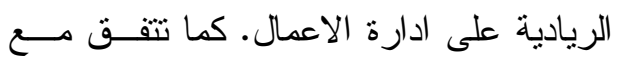

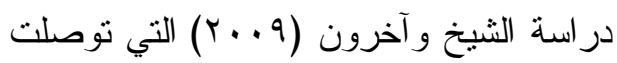

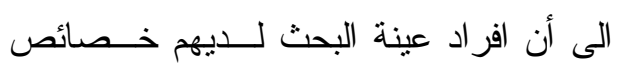
ريادية مرتفعة، وتختلف مع در اســة حسـين النه

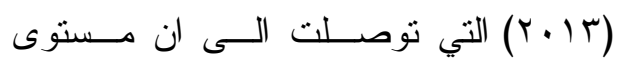

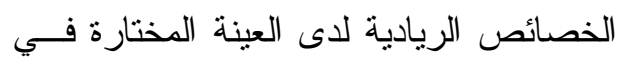
الميدان المبحوث منوسط.

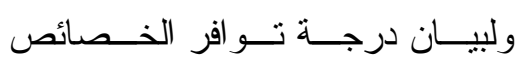

الريادية لاى قادة المدارس الحكومية بمحافظة بيشة تــم حسـاب المتوســـات الحسـابية و الانحر افات المعيارية على مستوى كل مجال

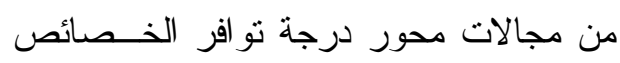

بالخصائص الريادية من خـــله العمليــات الإدارية الفعالة، واستخدام أنظمة المعلومات

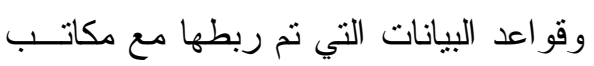
التعليم ووزارة التعليم، وكذلك مدى الاهتمام

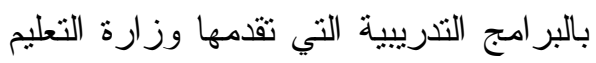

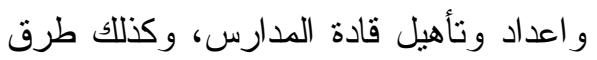
اختيار هم ووضع المعـايير لاختيــار قــادة وهئ المدارس بناء على عـــة خــصائص مــن ضمنها امتلالك القادة لسمات قيادية تمكنــهـ

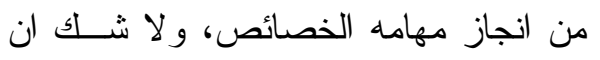

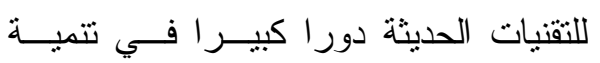

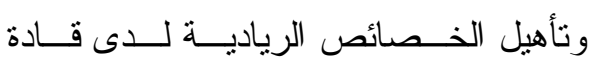
المدارس فاليوم المادة العلمية متاحة لكل من لرنادئ يريد ان ينمي قدر اته ومهار اته ، ويعد ذلك هلك

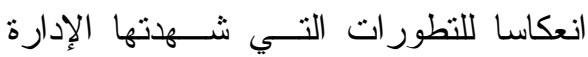

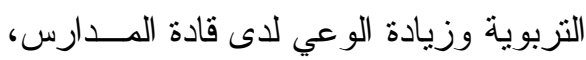

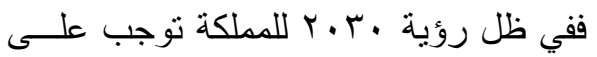
قادة المدارس البحث عـن أفـضل فضل الــسبل

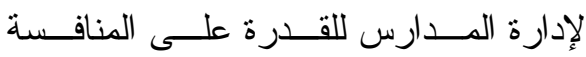
وتحقيق المتطلبات التعليمية الني تهذف لهـــا

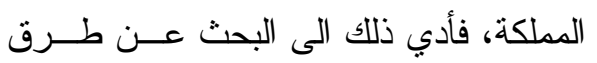

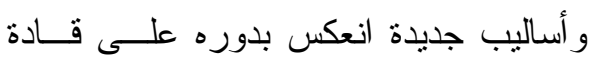
المدارس في اكتساب العديد من المهـــار ات لدون

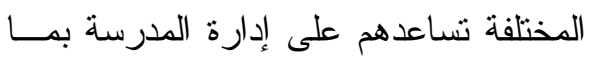

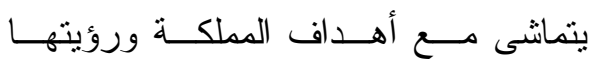
الطموحة. اما فيما يتعلق بوجـود الاسـتقلالية الريادية الخمسة كالآتي: 
القدرة على الإبداع "، وتم ترتيب هذه الفقرات المجال الأول: القدرة على الإبداع

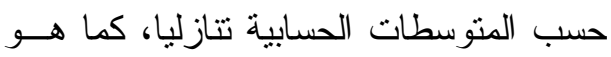

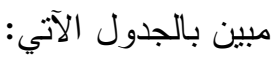
نم استخر اج المتوسطات الحسـسابية و الانحر افات المعيارية لاسـتجابات أفــر اد اد عينة الدراسة على مفردات المجال الأول " جدول (V) المتوسطات الحسابية والاتحر افات المعيارية لاستجابات أفراد عينة الدراسة على فقرات مجال القدرة على الإبداع مرتبة تنازليا حسب المتوسطات الحسابية

\begin{tabular}{|c|c|c|c|c|c|}
\hline التو درجة & 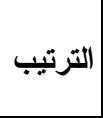 & الاحعراف & |الحستوسطي & 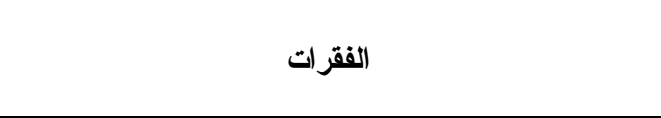 & رقلمق \\
\hline عالية & 1 & 1.010 & 4.04 & يمتلك قائد المدرسة مهارة طر ح البدائل لحل أب مشكلة. & 2 \\
\hline عالية & 2 & 1.022 & 4.02 & 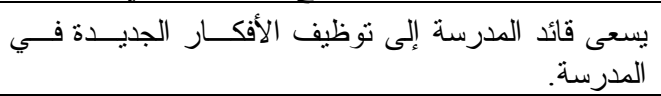 & 4 \\
\hline عالية & 3 & 1.014 & 4.03 & يثجع قائد الددرسة على استخدام وسائل التقنية الحديثة. & 8 \\
\hline عالية & 4 & 1.053 & 3.99 & الدهام. قيائد الددرسة أسلوب روح الجماعــة فـــي تتفــــذ & 6 \\
\hline عالية & 5 & 1.038 & 3.96 & يتعامل قائد الددرسة مع المشكلات التي تو اجهه كفرص. & 1 \\
\hline عالية & 6 & 0.992 & 3.95 & يتزجم قائد المدرسة الأفكار إلى مهام ونتائج. & 3 \\
\hline عالية & 7 & 1.012 & 3.90 & 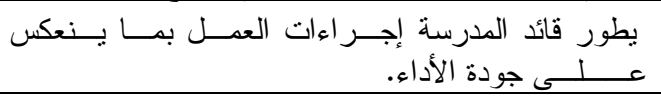 & 5 \\
\hline عالية & 8 & 1.076 & 3.88 & ينفذ قائد الددرسة مهامه بأساليب جديدة. & 7 \\
\hline عالية & & 0.825 & 3.97 & الدرجة الكلية للجال القدرة على الإبداع & \\
\hline
\end{tabular}

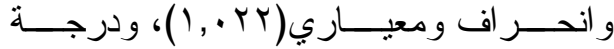

مارسة عالية، وفي المرنبة الثالثة الفقرة (^) "يشجع قائد المدرسة على اســتخدام وســائل

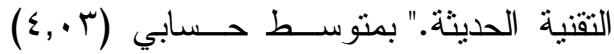
و انحـــر اف ومعيــاري (ع ا ب, (1)، ودرجـــة ممارسة عالية، وفي المرتبة السادسة الفقــرة

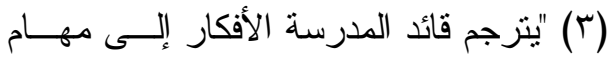

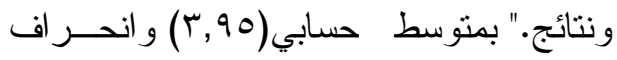
ومعياري(ب999, ·))، ودرجة ممارسة عاليــة، وفي المرنبة قبل الأخيرة الفقرة (0) "يطـــور

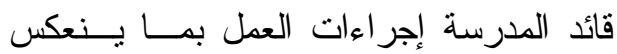

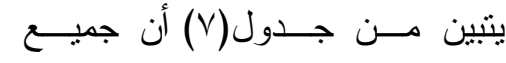

الفقر ات الثمانية جاءت بمتوسطات حسسابية تقع في درجة نو افر (عالية)، فقد جاءت في باعن

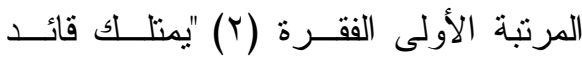

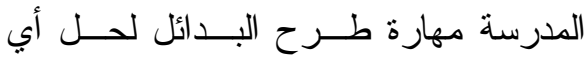

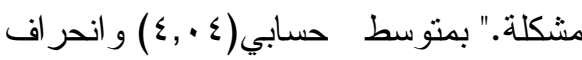
ومعياري (· • •, (1)، ودرجة ممارسة عالية،

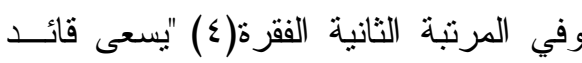

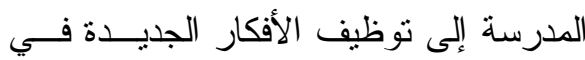

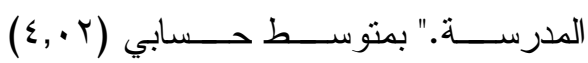


اللحظة نفسها او قد تكون نتيجة مرور القائــــ بنفس الموقف وقد يطور القائد هذه الأفكـار

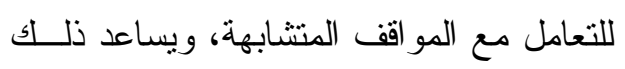
استخدامه وسائل التقنية الحديثة التي تمكنه من

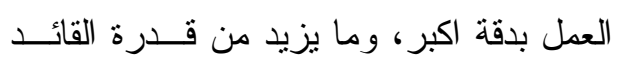

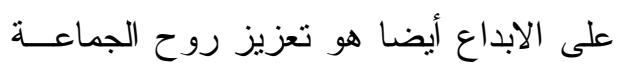

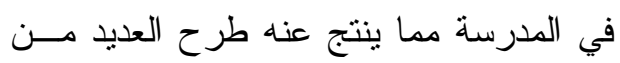

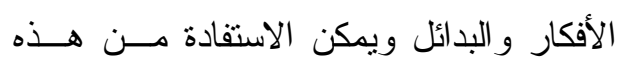
الأفكار ونوظيفها، وما يمتلكه القادة من سمات

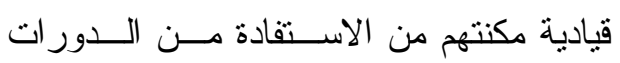
التدريبية المقدمة لهم، مما رفع قدرثهم علـى الانى الابداع.

حيث تنفق هذه النتيجة مـــع دراســة

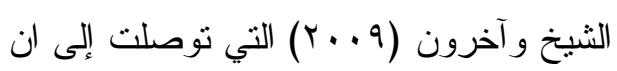
افر اد عينة البحث يتمتعون بدرجة عالية مسن القدرة على الابداع.

المجال الثاني: المخاطرة الماع

تم استخر اج المتوســـات الحـسابية و الانحر افات المعيارية لاستجابات أفراد عينة

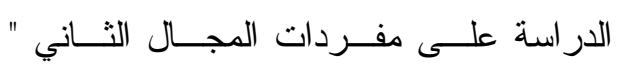
المخاطرة "، ونم ترتيب هذه الفقر ات حسسب

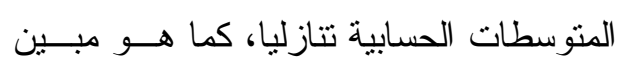
بالجدول الآتي:

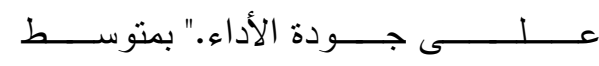

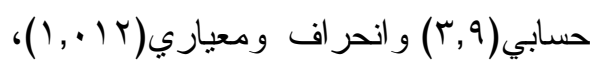
ودرجة ممارسة عالية، وفي المرتبة الأخيرة

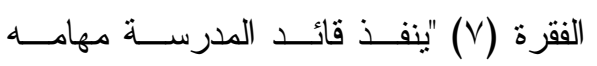

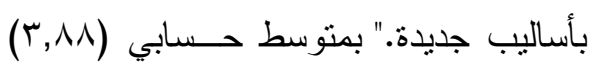

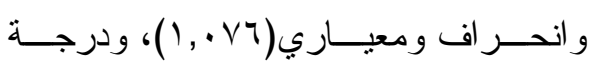
ممارسة عالية. وتشير هذه المتوسطات إلى تطبيق

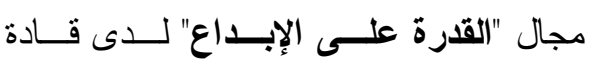
المدارس الحكومية بمحافظة بيشة من وجهة

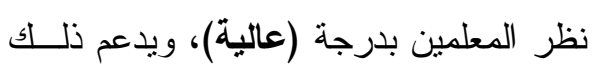

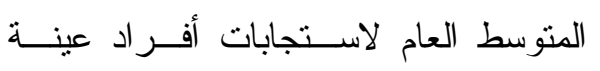

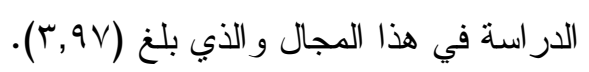

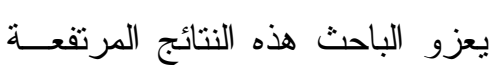

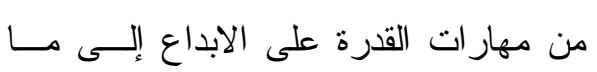

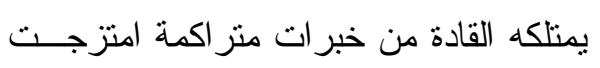

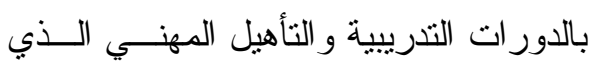
تلاقاه قادة المدارس، مما رفع لديهم قدرتهم

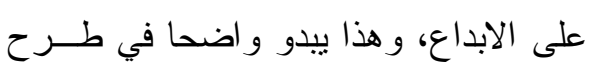

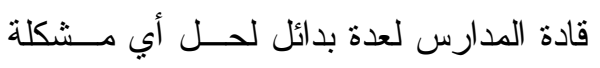

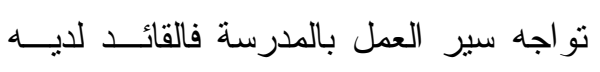

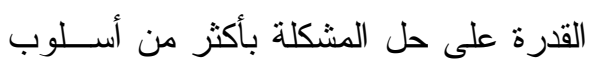

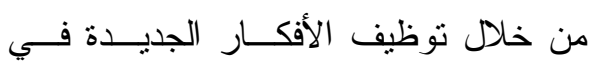
المدرسة، وهذه الأفكار قد تكون نابعة فــي لـي 


\section{جدول (^) المتوسطات الحسابية والاتحر افات المعيارية لاستجابات أفراد عينة الاراسة}

على فقرات مجال المخاطرة مرتبة تنازليا حسب المتوسطات الحسابية

\begin{tabular}{|c|c|c|c|c|c|}
\hline المرارسة & تيب & المعياري & الحسابي & الفقرات & رقفرة \\
\hline عالية & 1 & 1.103 & 3.87 & يمتلاك قائد المدرسة الجر أة في اتخاذ القرارات الصعبة. & 14 \\
\hline عالية & 2 & 1.024 & 3.85 & يمتلاك قائد المدرسة القدرة على تحمل نتائج المخاطرة. & 15 \\
\hline عالية & 3 & 1.074 & 3.84 & يؤمن قائد المدرسة بضرورة مو اجهة تغير ات البيئة المفاجئة. & 13 \\
\hline عالية & 4 & 1.115 & 3.83 & يشعر قائد المدرسة برغبة كبيرة في تحدي الصعاب. & 11 \\
\hline عالية & 5 & 1.052 & 3.82 & لدى قائد الددرسة القدرة على تحمل مخاطر العمل. & 12 \\
\hline عالية & 6 & 1.106 & 3.81 & بمخيل قائد المدرسة للعمل بجر اءة في الحالات التــي تتـسم & 9 \\
\hline عالية & 7 & 1.105 & 3.76 & يمتلك قائد المدرسة الرغبة في المغامرة في أداء الأعمال. & 10 \\
\hline عالية & & 0.889 & 3.83 & الدر حة الكلية لمحال المخاطرة & \\
\hline
\end{tabular}

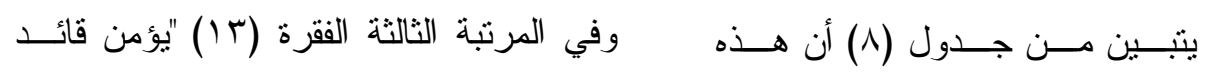

المدرسة بضرورة مواجهة تغيــرات البيئــة

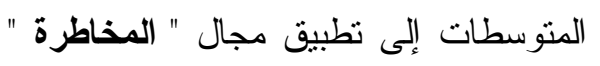

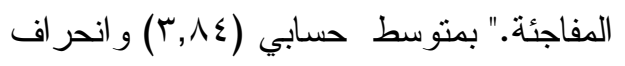

لدى قادة المدارس الحكومية بمحافظة بيشة لمبنة

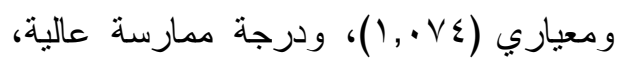

من وجهة نظر المعلمين بدرجة (عاليــة)، وفي المرتبة الخامسة الفقرة (Y I) "لدى قائــد

ويدعم ذلك المتوسط العام لاستجابات أفراد

المدرسة القدرة على تحمل مخاطر العمــل."

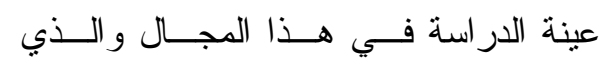
بمتوسط حسابي (r,^r,) و انحر اف ومعياري

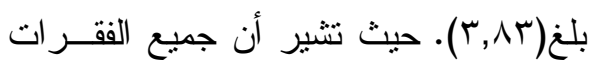

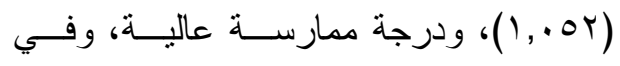
السبعة جاءت بمتوسطات حسابية تقع فــي

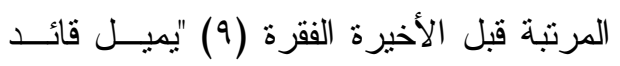
درجة نو افر(عالية)، فقد جاءت في المرتبة المدرسة للعمل بجر اءة في الحالات التي تتسم

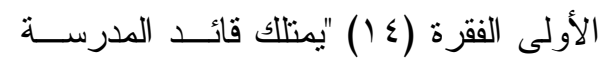

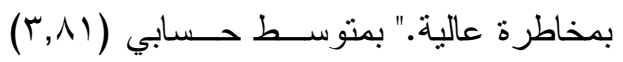

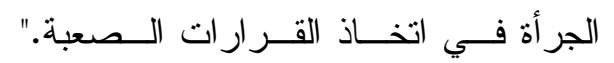

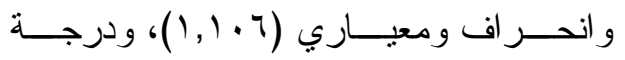

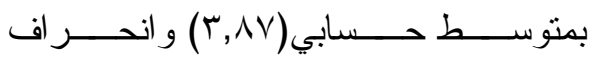
ممارسة عالية، وفي المرنبة الأخيرة الفقــرة ودرة

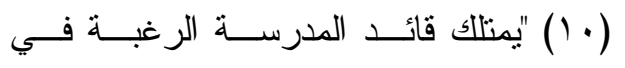
ومعياري(r + 1,1)، ودرجة ممارسة عالية،

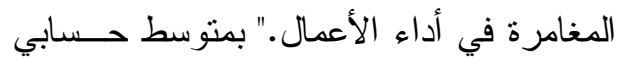

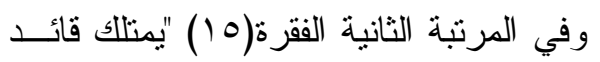
المدرسة القدرة على تحمل نتائج المخاطرة."

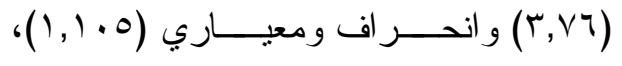

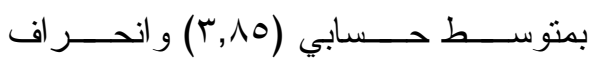
ودرجة ممارسة عالية. ومعياري (ع ب. , (1)، ودرجة ممارسة عالية، 
الاختيار الأخير لقائد المدرسة اذا لم يجد مــن

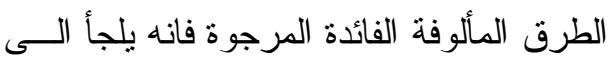

المخاطرة في اتخاذ القرار ات.

\section{المجال الثالث: الاستقلالية}

تم استخر اج المتوســطات الحسـسابية

والانحر افات المعيارية لاستجابات أفراد عينة

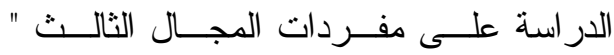

الاستقلالية "، وتم ترتيب هذه الفقرات حسسب

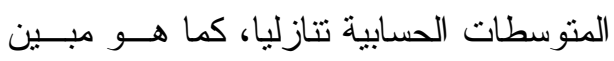

$$
\text { بالجدول الآتي(9): }
$$

ويمكن تفسير ذلك أن قادة المدارس

لايهم مساحة كبيرة من اتخاذ القرارات و ان

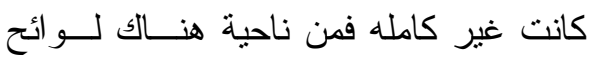
و أنظمة يرنبط بها قادة المدارس ومن ناحية

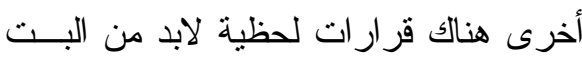

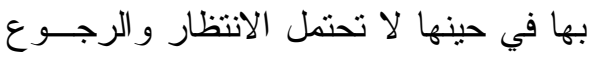
الى المستويات العليا ومكاتب التعليم، وهذا ما يفسر ان اتخاذ القرار ات الصعبة جاء في المقدمة والتي دائما ما تكون قرار ات يومية،

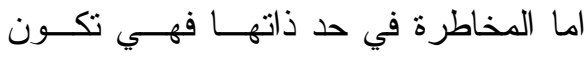

جدول (9) المتوسطات الحسابية والاحمر افات المعيارية لاستجابات أفراد عينة الدراسة

على فقرات مجال الاستقلالية مرتبة تنازليا حسب المتوسطات الحسابية

\begin{tabular}{|c|c|c|c|c|c|}
\hline 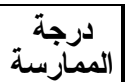 & الترتيب & 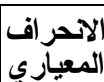 & 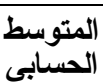 & الفقرات & الفقزّة \\
\hline عالية & 1 & 1.014 & 3.98 & يعمل قائد المدرسة بالأفكار و الحلول المقتتع بها. & 16 \\
\hline عالية & 2 & 1.018 & 3.88 & التيادر قياتئد المدرسة بنقديم حلول لأي مـشكلة دون انتظـــار & 21 \\
\hline عالية & 3 & 1.098 & 3.87 & الأعمالر الجديدة. المدرسة مع الآخرين حــول إمكانيـــة تطــــير & 19 \\
\hline عالية & 4 & 1.066 & 3.81 & ضيويل قائد المدرسة العملى الاستقلالية في اتخاذ قر ار اته بنفسه في & 17 \\
\hline عالية & 5 & 1.039 & 3.81 & يتخذ قائد المدرسة القر ار ات المستقبلية بدون تردد. & 20 \\
\hline عالية & 6 & 1.056 & 3.76 & لدى قائد المدرسة حرية كافية لتطبيق الأفكار الجديدة. & 18 \\
\hline عالية & 7 & 1.043 & 3.73 & 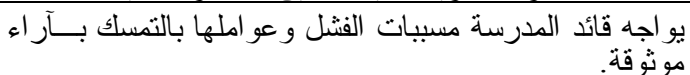 & 22 \\
\hline عالية & & 0.810 & 3.83 & الدرجة الكلية لمجال الاستقلالية & \\
\hline
\end{tabular}

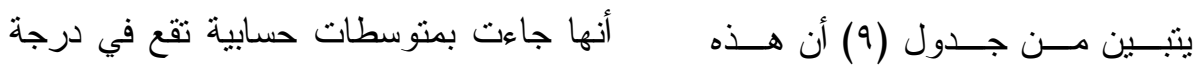
تو افر (عالية)، فقد جاءت في المرتبة الأولى

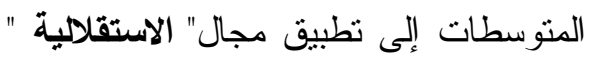

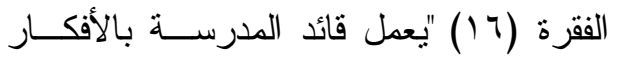
لدى قادة المدارس الحكومية بمحافظة بيشة

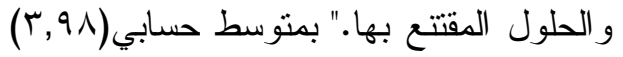
من وجهة نظر المعلمين بدرجة (عاليــة)،

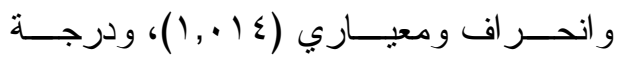
ويدعم ذلك المتوسط العام لاستجابات أفراد ممارسة عالية، وفي المرنبة الثنانيــة الفقــرة ودرة

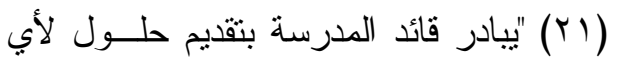

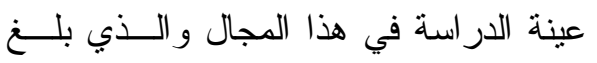

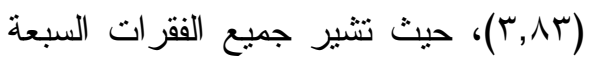




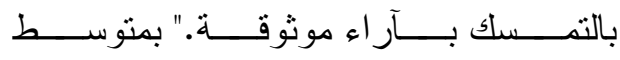

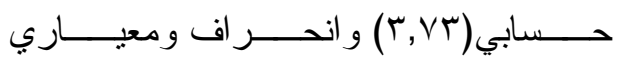
( ) (1) ) (1)، ودرجة ممارسة عالية.

مما يعكس إدر الك قادة المدارس بأهمية الاستقلالية في اتخاذ القرار ات، و على الـــرغم

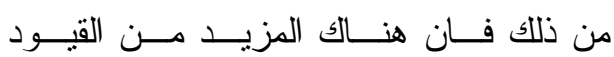

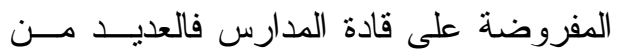

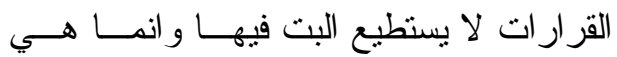
تكون وفـق الأدلـــة التتظيميــة و الاجر ائيـــة و التعاميم من وزارة التعليم، ولذا يتحرك قائد المدرسة في المساحة المتاحة له و الاســتفادة ولئاة الكاملة منها.

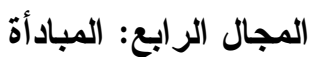

تم استخر اج المتوســطات الحـسـابية

و الانحر افات المعيارية لاستجابات أفراد عينة الدر اسة على مفردات المجال الر ابع "المبادأة"، وتم ترتيب هذه الفقرات حسب المتوســـات

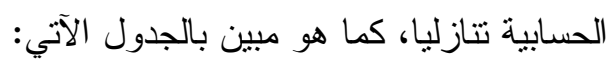

مــشكلة دون انتظـــار التوجيهــات مــن

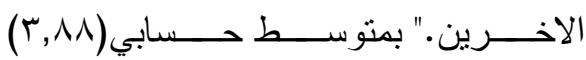

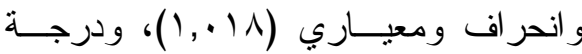
ممارسة عالية، وفي المرتبة الثالثة الفقـرة ودة الثرة (9 (1) "يتحاور قائد المدرسة مع الآخــــين

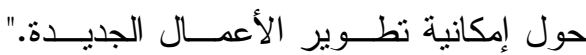

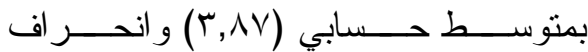
ومعياري (91 . , (1)، ودرجة ممارسة عالية،

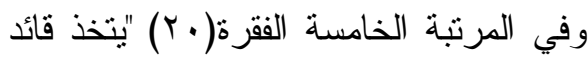
المدرسة القرارات المستقبلية بدون تــــدد."

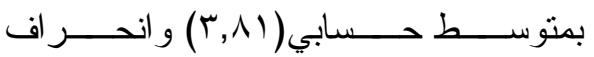

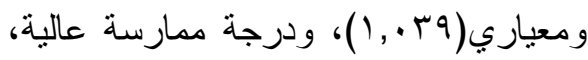

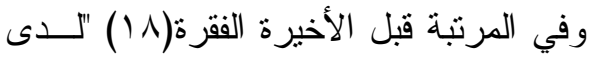
قائد الددرسة حرية كافية لتطبيــق الأفكــار

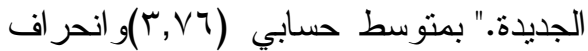
ومعياري (1.07.07)،ودرجة ممارسة عالية،

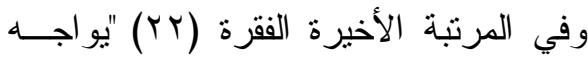

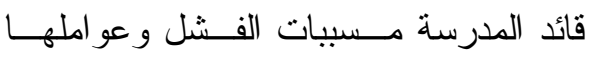

جدول ( • 1) المتوسطات الحسابية والاتحرافات المعيارية لاستجابات أفر اد عينة الدراسة داسة

على فقرات مجال المبادأة مرتبة تنازليا حسب المتوسطات الحسابية

\begin{tabular}{|c|c|c|c|c|c|}
\hline الممارسة & الترتي & المعياري & الحسابي & الفقرات & رقفرة \\
\hline عالية & 1 & 1.000 & 3.95 & الثقارير مبائشرة. المدرسة على إنجاز جو انب العطل المختلفة مـن خـــد & 29 \\
\hline عالية & 2 & 0.978 & 3.93 & يسعى قائد المدرسة نحو استثمار الفرص الجديدة في العمل. & 23 \\
\hline عالية & 3 & 1.028 & 3.91 & يسعى قائد الددرسة لمستوى أداء و إنجاز أفضل من الآخرين. & 26 \\
\hline عالية & 4 & 1.054 & 3.85 & يبيادر قائد المدرسة نحو الاستفادة من التطورات العلمية في مجال العمل. & 25 \\
\hline عالية & 5 & 1.019 & 3.85 & يبني قائد المدرسة علاقات داعمه مع زملاء العطل لنظوير الذدمات المقدمة. & 24 \\
\hline عالية & 6 & 1.063 & 3.79 & يقوم قائد الددرسة بأعمال تتجاوز مهامه من أجل التطوير . & 27 \\
\hline عالية & 7 & 1.097 & 3.72 & ينجز قائد المدرسة الأعمال قبل أن تفرضها عليه الأحداث. & 28 \\
\hline \multicolumn{2}{|l|}{ عالية } & 0.852 & 3.86 & 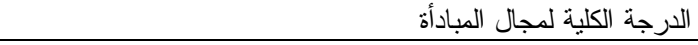 & \\
\hline
\end{tabular}


ومعياري (9 (1, (1)، ودرجة ممارسة عالية،

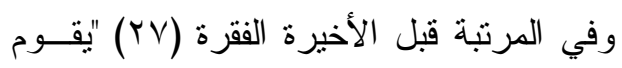

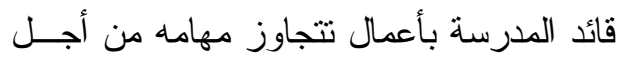

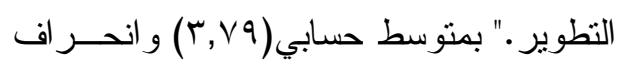

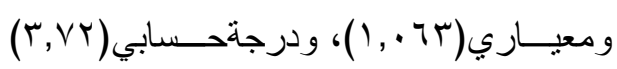

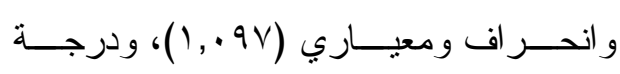
ممارسة عالية.

ويمكـن تفـسير ذلــك فــي ضـــوء

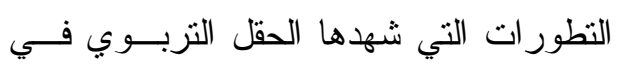

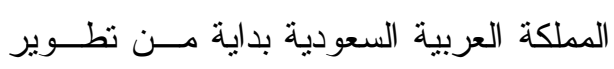

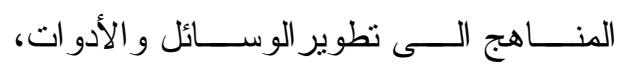
فكثير من العثزات التي كانت تواجه المعلمين

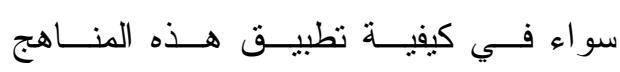

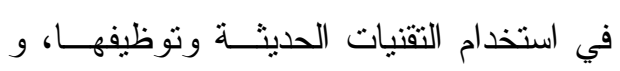
هذه النتائج تعكس تصور المعلمين الإيجـابي

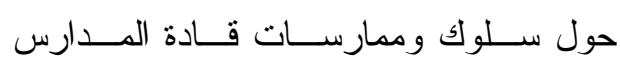
لمهامهم، من حيث الاهتمام بالتطور ات العلمية

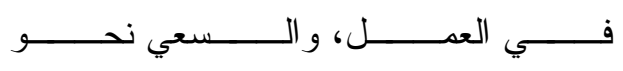
استثمار الفرص الجديدة، وقدرة قائد المدرسة

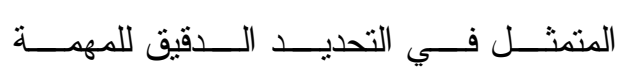
المطلوبة لكل معلم، ووضع معايير لما يتوقعه

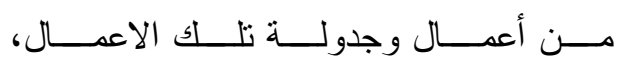
ومن هنا كان لقائـــــ المدرســـة دوراً بـــارزاً في مساعدة المعلمين لتخطي هذه العقبات من خلال رغبة قادة المدر اس باتخــاذ المبادأة منهجا له من اجل مساعدة الاخــرين على نطوير انفسهم.

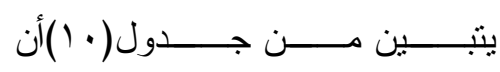

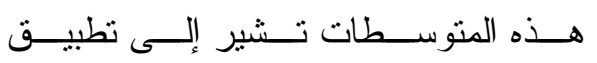
مجال "المبادأة" لاى قادة المدارس الحكومية بمحافظة بيشة من وجهة نظــر المعلمـين

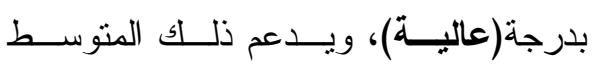

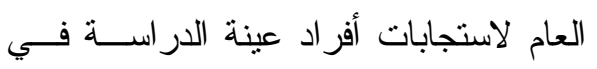

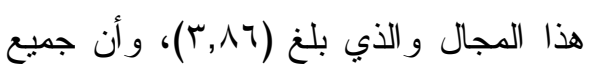
الفقرات السبعة جاءت بمتوسطات حسسابية تقع في درجة نو افر (عالية)، حيث جــاءت

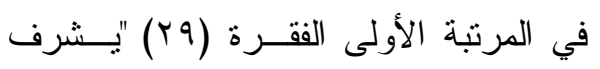

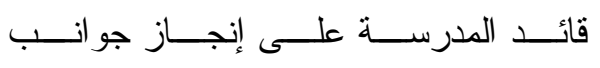
العمل المختلفة من خلال التقارير مباشرة."

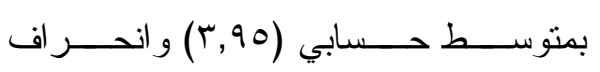
ومعياري( (., (1)، ودرجة ممارسة عالية، وفي المرنبة الثانية الفقرة (rr) "يسعى قائد المدرسة نحو اســتمار الفـرص الجديــدة

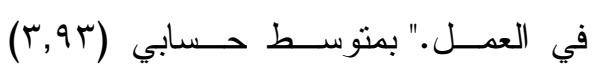

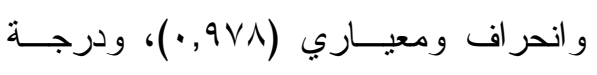

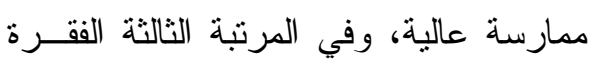

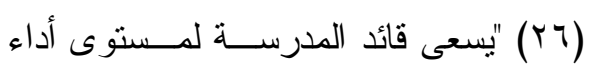

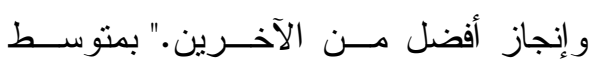

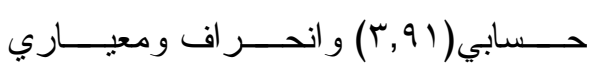

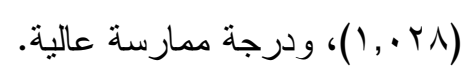

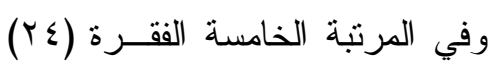

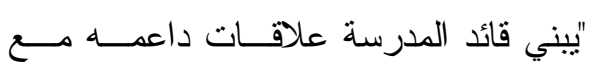
زملاء العمل لتطوير الخــدمات المقدمــة."

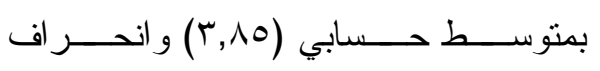




\section{المجال الخامس: الثقة بالنفس}

تم استخر اج المتوســطات الحـسـابية

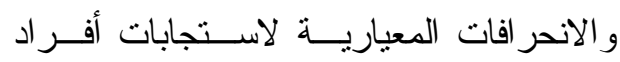

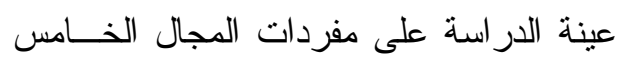

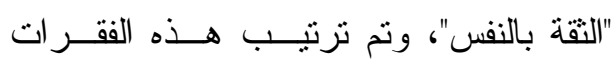

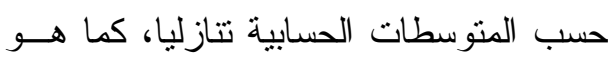

$$
\text { مبين بالجدول الآتي: }
$$

وتساعد المبادأة على تحفيز التغييــر

و التطوير و التجديد فهي أحد مدخلات عملية

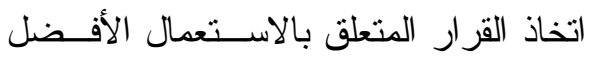

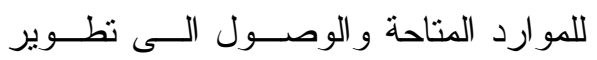
طر ائق و أساليب جديدة للعمليات.

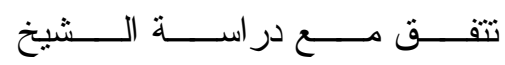

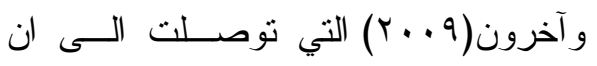
افراد عينة البحث يتمتعون بدرجة عالية من

جدول (11)

المتوسطات الحسابية والاتحر افات المعيارية لاستجابات أفر اد عينة الدراسة

على فقرات مجال الثقة بالنفس مرتبة تنازليا حسب المتوسطات الحسابية

\begin{tabular}{|c|c|c|c|c|c|}
\hline 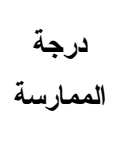 & الترتي & الانحرا & الحستوسطي & الفقر ات & رق الفقرة \\
\hline عالية & 1 & 0.925 & 4.03 & يشعر قائد المدرسة بثقة عالية في القدرة على بلو غ الأهداف. & 30 \\
\hline عالية & 2 & 1.052 & 4.01 & يمنح قائد المدرسة الثقة في زملاءه لأداء مهامهم الموكلة لهم. & 38 \\
\hline عالية & 3 & 1.019 & 3.95 & يفضل قائد المدرسة الحسم عندما يتخذ قر ار ا حاسما. & 35 \\
\hline عالية & 4 & 1.065 & 3.94 & لالددرسة. لائد المدرسة القدرة على رؤية ميــول ورغبــات العـاملين & 31 \\
\hline عالية & 5 & 1.040 & 3.90 & يسنطيع قائد المدرسة إقناع الآخرين بر أيه في حال الصواب. & 34 \\
\hline عالية & 6 & 1.053 & 3.88 & يو اجه قائد المدرسة المشكلات في بيئة العمل بثبات & 33 \\
\hline عالية & 7 & 1.009 & 3.85 & يستمر قائد المدرسة على الحلول الجديدة في العمل بشكل دائم. & 32 \\
\hline عالية & 8 & 1.043 & 3.85 & بيه. بحكم قائد المدرسة في معظم الأحيان بالمو اقف و الأحداث المحيطة & 37 \\
\hline عالية & 9 & 1.093 & 3.77 & عندما يخفق قائد المدرسة في عمل معين يزداد اصر اره تجاهه. & 36 \\
\hline عالية & & 0.804 & 3.91 & الدرجة الكلية لمجال الثقة بالنفس & \\
\hline
\end{tabular}


الأخيرة الفقرة (rV) "يتحكم قائد الددرسة في معظم الأحيان بالمو اقف والأحداث المحيطة

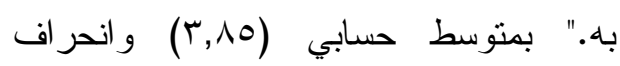

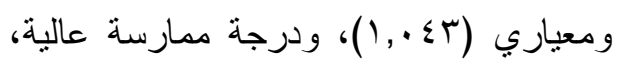

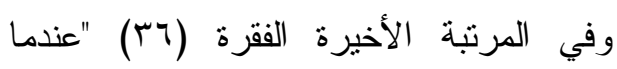
يخفق قائد المدرسة في عمل معين الاحيرة يزداد اصر اره تجاهه." بمنوسط حسابي (r,YV)

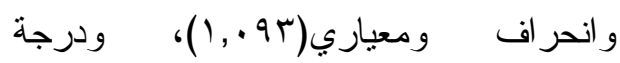

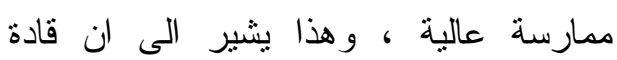

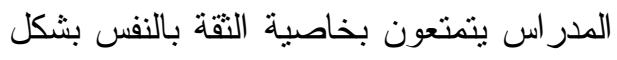

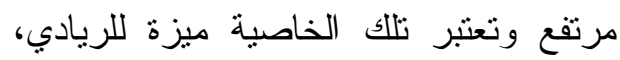

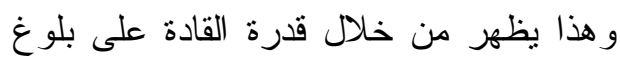
الأهداف ومنح قائد المدرسة الثقة في زملاءه

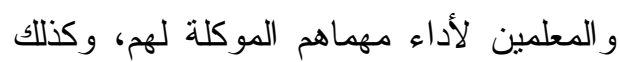

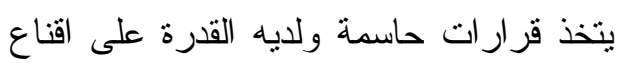
الاخرين من خلال معرفته بميول ورغبات الاخرين، ويدعم هذه الثقة ما يتمتع به موقع بدئ مدير المدرسة من تقدير المعلمين، كما ان هناك قرار ات الز امية لكل من القادة وجميع نقير العاملين في المدرسة لا يمكن تخطيها، ولكن

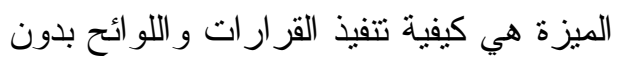
ان يكون هناك تقصير في العمل او تذمر ولا يأتي ذلك الا من قائد لديه ثقة مرتفعة بنفسه،

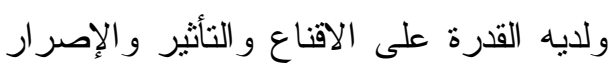
على النجاح.

وتتفق هذه النتائج مع دراسة سعدية

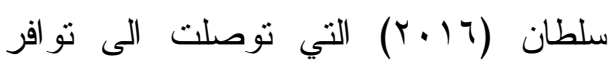

يتبــين مسن جـدول(1) (1) أن هـــه

المتوسطات نتشير إلى تطبيق مجال" الثقـــة

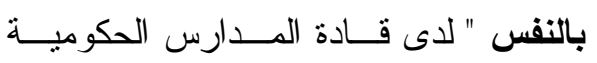

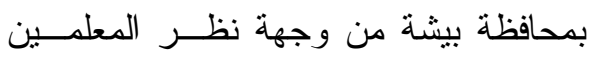
بدرجة (عالية)، ويدعم ذلك المتوسط العـام

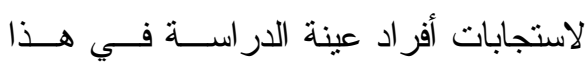

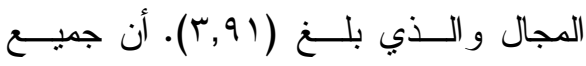
الفقرات التسعة جاءت بمنوسطات حسـسابية تقع في درجة نو افر (عالية) ، فقد جاءت في بـاءت

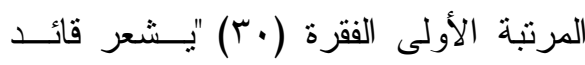

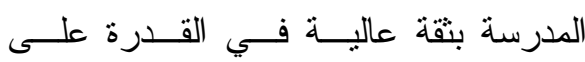

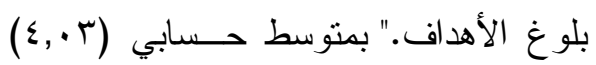

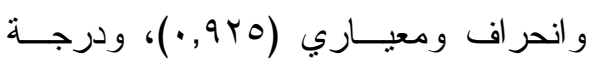

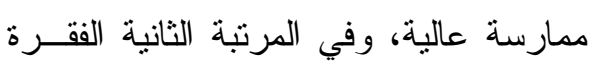

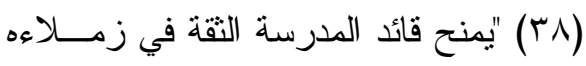
لأداء مهامهم الموكلة لهم." بمتوسط حسابي

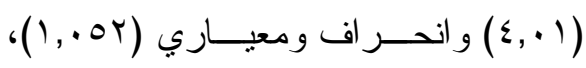
ودرجة ممارسة عالية، وفي المرتبة الثالثــة

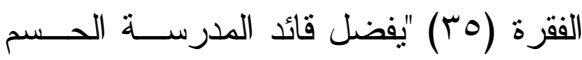
عندما يتخذ قرار ا حاسما." بمتوسط حسابي

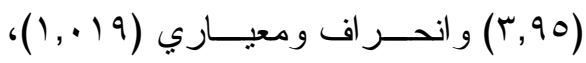
ودرجة ممارسة عالية.

وفي المرتبة السابعة الفقرة (rT) "يستمر قائد المدرسة على الحلول الجديدة في العمل بشكل دائم." بمنوسط حسابي (r,10) ودرجة ممارسة عالية، وفي المرتبة قبل وميلاريل 
أولا: بالنسبة لمتغير المرحلة التعليمية: لمعرفة دلالة الفروق الإحصائية عند مستوى الدلالة (1<0.05) في متوسطات

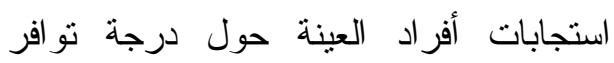
الخصائص الريادية لدى قادة المدارس في

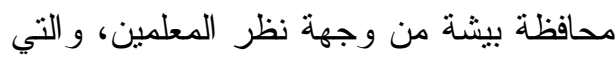

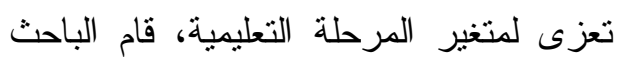

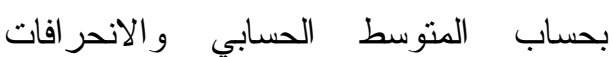
المعيارية لقيمة "ف" طبقا لاختبار تحليل التباين الأحادي (One -Way ANOVA) لاستجابات أفراد عينة الدراسة حول درجة نو افر الخصائص الريادية لدى قادة المدارس في محافظة بيشة، من وجهة نظر القادة المعلمين، و والتي تعزى ل لمتغير المرحلة التعليمية.

حيث تم حساب المتوسطات الحسابية و الانحر افات المعيارية لدرجات استجابات

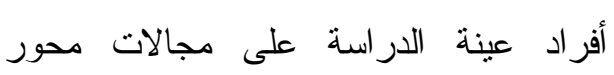

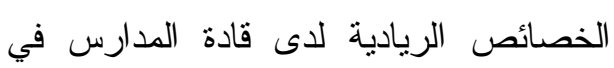

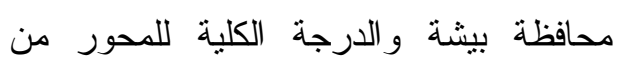
وجهة نظر المعلمين، وفق متغير (المرحلة التعليمية) و هذا ما يبينه الجدول( ب ( ):
مجال الثقة بالنفس بدرجة عالية لاى افراد

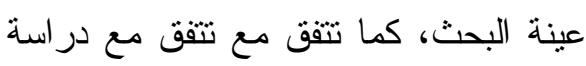

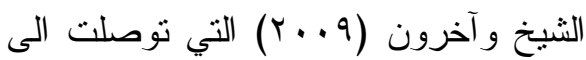
ان افر اد عينة البحث يتمتعون بدرجة عالية من الثقة بالنفس.

\section{نتائج السؤال الثاني ومناقشتها وتفسيرها:}

هل نوجد فروق ذات دلالة إحصائية

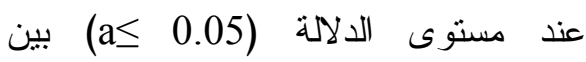
متوسطات استجابة أفراد العينة لدرجة تو افر الخصائص الريادية لدى قادة المدارس في

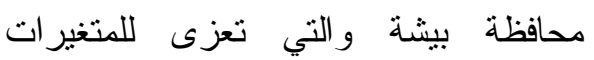
(المرحلة التعليمية - الدورات التدريبيةسنوات الخبرة - مكتب التعليم التابعة له المدرسة)؟ - (الجن وللإجابة عن هذا التساؤل نم استخدم اختبار - ت (T-Test) لعينتين مستقلتين للكثف عن دلالة الفروق الإحصائية

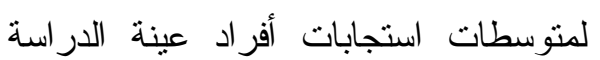
التي تعزى لمتغيري: (الدورات التدريبية، وسنوات الخبرة)، وتحليل التباين الأحادي لني (One -way AN0VA) (سنوات الخبرة، المرحلة التعليمية، ومكتب التعليم التابعة له المدرسة) وفيما ليلي توضيح لذللك. 
جدول (r I ) المتوسطات الحسابية والاتحر افات المعيارية لمجالات محور الخصائص الريادية لاى قادة المدارس في محافظة بيشة والدارجة الكلية والانية

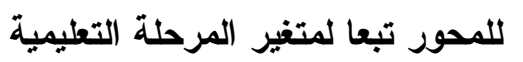

\begin{tabular}{|c|c|c|c|c|}
\hline الاحر اف المعياري & |المتوسط الحسابي & العدد & المرحلة التعليمية & المجال \\
\hline 0.832 & 3.98 & 176 & ابتدائي & \multirow{4}{*}{ المجال الأول: القدرة على الإبداع } \\
\hline 0.869 & 3.94 & 69 & متوسط & \\
\hline 0.789 & 3.97 & 105 & ثانوي & \\
\hline 0.825 & 3.97 & 350 & المجموع & \\
\hline 0.908 & 3.83 & 176 & ابتدائي & \multirow{4}{*}{ المجال الثاني: المخاطرة } \\
\hline 0.976 & 3.82 & 69 & متوسط & \\
\hline 0.801 & 3.83 & 105 & ثانوي & \\
\hline 0.889 & 3.83 & 350 & المجموع & \\
\hline 0.818 & 3.87 & 176 & ابتدائي & \multirow{4}{*}{ المجال الثالث: الاستقلالية } \\
\hline 0.818 & 3.77 & 69 & متوسط & \\
\hline 0.795 & 3.82 & 105 & ثانوي & \\
\hline 0.810 & 3.83 & 350 & المجموع & \\
\hline 0.902 & 3.88 & 176 & ابتد ائي & \multirow{4}{*}{ المجال الر ابع: المبادأة } \\
\hline 0.850 & 3.84 & 69 & منو سط & \\
\hline 0.770 & 3.83 & 105 & ثنانوي & \\
\hline 0.852 & 3.86 & 350 & المجموع & \\
\hline 0.835 & 3.94 & 176 & ابتدائي & \multirow{4}{*}{ المجال الخامس: الثقة بالنفس } \\
\hline 0.829 & 3.89 & 69 & متوسط & \\
\hline 0.736 & 3.86 & 105 & ثنانوي & \\
\hline 0.804 & 3.91 & 350 & المجموع & \\
\hline 0.805 & 3.90 & 176 & ابتدائي & \multirow{4}{*}{ الخصائصة الآلية لمحور نو الدرسة لدى فادة } \\
\hline 0.811 & 3.85 & 69 & منو سط & \\
\hline 0.694 & 3.86 & 105 & ثانوي & \\
\hline 0.773 & 3.88 & 350 & المجموع & \\
\hline
\end{tabular}

التعليمة. ولتحديد فيما إذا كانت هذه الفروق

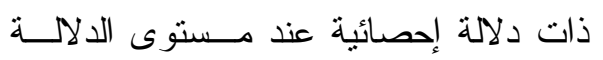

ينبين من الجدول(Y) وجود فروق

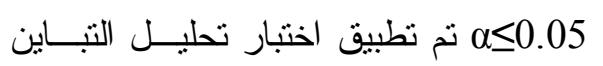

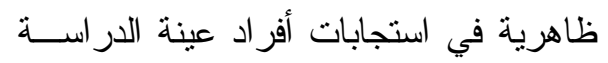

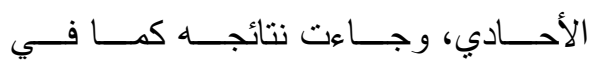

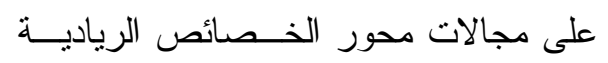

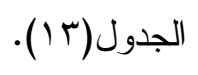

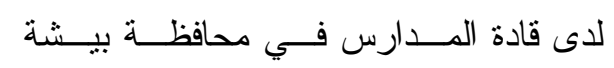

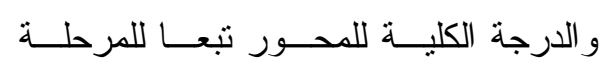


جدول (r I ) اختبار تحليل التباين الأحادي (One -Way Anova) للكشف عن دلالة الفروق لمجالات محور الخصائص الريادية لاى قادة المدارس في محافظة بيثة والادين الدارجة الكلية للمحور وفقا لمتغير المرحلة التعليمية فيادية

\begin{tabular}{|c|c|c|c|c|c|c|}
\hline مستوى الدلائة & قيمة ف & متوسط المربعات & الحرجة & المربعات & مصدر التباين & المجالات \\
\hline \multirow{3}{*}{0.932} & \multirow{3}{*}{0.071} & 0.048 & 2 & 0.10 & بين المجموعات & \multirow{3}{*}{ لمجال الأول: القدرة على الإبداع| } \\
\hline & & 0.684 & 347 & 237.35 & داخل المجموعات & \\
\hline & & & 349 & 237.44 & الإجمالي & \\
\hline \multirow{3}{*}{0.996} & \multirow{3}{*}{0.004} & 0.003 & 2 & 0.01 & بين المجموعات & \multirow{3}{*}{ المجال الثاني: المخاطرة } \\
\hline & & 0.795 & 347 & 275.94 & داخل المجموعات & \\
\hline & & & 349 & 275.95 & الإجمالي & \\
\hline \multirow{3}{*}{0.694} & \multirow{3}{*}{0.365} & 0.240 & 2 & 0.48 & بين المجموعات & \multirow{3}{*}{ المجال الثالث: الاستقلالية } \\
\hline & & 0.658 & 347 & 228.34 & داخل المجموعات & \\
\hline & & & 349 & 228.82 & الإجمالي & \\
\hline \multirow{3}{*}{0.871} & \multirow{3}{*}{0.138} & 0.101 & 2 & 0.20 & بين المجموعات & \multirow{3}{*}{ المجال الر ابع: المبادأة } \\
\hline & & 0.729 & 347 & 253.03 & داخل المجمو عات & \\
\hline & & & 349 & 253.23 & الإجمالي - الي & \\
\hline \multirow{3}{*}{0.709} & \multirow{3}{*}{0.345} & 0.223 & 2 & 0.45 & بين المجموعات & \multirow{3}{*}{ المجال الخامس: الثقة بالنفس } \\
\hline & & 0.648 & 347 & 224.92 & داخل المجموعات & \\
\hline & & & 349 & 225.36 & الإجمالي & \\
\hline \multirow{3}{*}{0.879} & \multirow{3}{*}{0.129} & 0.077 & 2 & 0.15 & بين المجموعات & \multirow{3}{*}{ 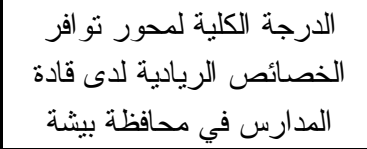 } \\
\hline & & 0.600 & 347 & 208.23 & داخل المجموعات & \\
\hline & & & 349 & 208.38 & الإجمالي & \\
\hline
\end{tabular}

محافظة بيشة تعزى لاختلاف متغير تشير النتائج في جدول (13) إلى أن المرحلة التعليمية ولك قد يعود الى أن جميع لئه قيمة "ف" غير دالة احصائيا عند مسنوى القادة في المراحل التعليمية لهم نفس النظام

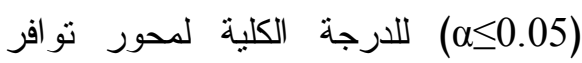
و العمل في القيادة.

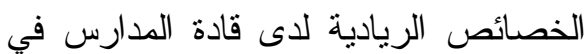
ثانياً: بالنسبة لمتغير الاورات التدريبية لحساب دلالة الفروق الإحصائية عند محافظة بيشة وجميع مجالاته، مما يعني

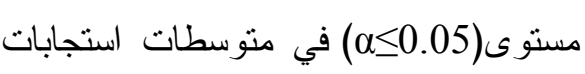
عدم وجود فروق ذات دلالة إحصائية عند مستوى الدلالة (a

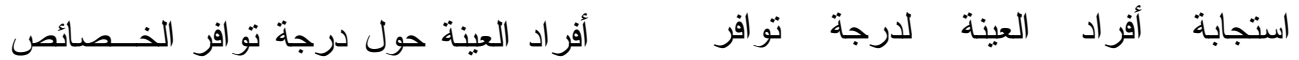
الخصائص الريادية لدى قادة المدارس في الريادية لدى قادة المدارس في محافظة بيشة 
الريادية لدى قادة المدارس في محافظة بيشة من وجهة نظـــر المعلمــين التــي تعـزى

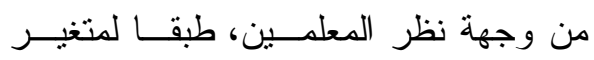

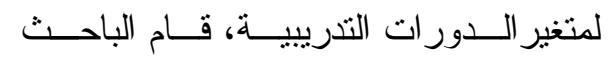

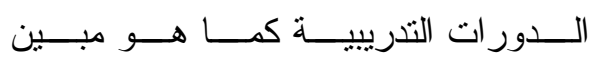

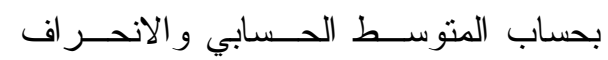

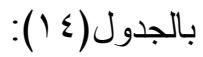
المعياري، وقيمة اختبار (ت)لاستجابات أفراد

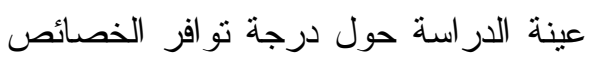

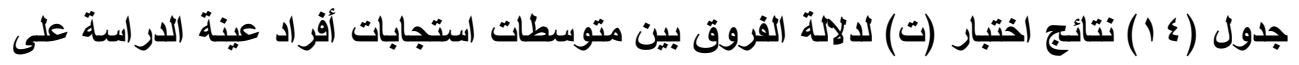
دلالة الفروق لمجالات محور توافر الخصائص الريادية لاى قادة المدارس في محافظة بيشة والدرجة الكلية للمحور تبعا لمتغير الدورات التدريبية

\begin{tabular}{|c|c|c|c|c|c|c|c|}
\hline مستوى الالالة & الحرية & $ت$ & الانحر افياري & الحستبط & $\dot{~ ن}$ & سنوات الخبرة & المجالات \\
\hline \multirow[t]{2}{*}{0.335} & \multirow[t]{2}{*}{348} & \multirow[t]{2}{*}{0.965} & 0.757 & 4.03 & 130 & أقل من دورات & \multirow{2}{*}{ 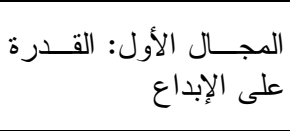 } \\
\hline & & & 0.862 & 3.94 & 220 & 0 دور ات فأكثر & \\
\hline \multirow[t]{2}{*}{0.184} & \multirow[t]{2}{*}{348} & \multirow[t]{2}{*}{1.331} & 0.799 & 3.91 & 130 & أقل من 0 & \multirow{2}{*}{ المجال الثاني: المخاطرة } \\
\hline & & & 0.937 & 3.78 & 220 & ه دور ات فأكثز & \\
\hline \multirow[t]{2}{*}{0.180} & \multirow[t]{2}{*}{348} & \multirow[t]{2}{*}{1.344} & 0.769 & 3.91 & 130 & أقل من 0 & \multirow{2}{*}{ الاستقلالية المــــــال الثالــــــــ } \\
\hline & & & 0.831 & 3.79 & 220 & 0 دور ات فأكثر & \\
\hline \multirow[t]{2}{*}{0.205} & \multirow[t]{2}{*}{348} & \multirow[t]{2}{*}{1.269} & 0.733 & 3.93 & 130 & أقل من دورات & \multirow{2}{*}{ المجال الر ابع: المبادأة } \\
\hline & & & 0.913 & 3.81 & 220 & 0 دور ات فأكثر & \\
\hline \multirow[t]{2}{*}{0.084} & \multirow[t]{2}{*}{348} & \multirow[t]{2}{*}{1.983} & 0.695 & 4.02 & 130 & أقلّ من 0 & \multirow{2}{*}{ بالنفس المجال الخامس: الثقـــة } \\
\hline & & & 0.856 & 3.84 & 220 & م دور ات فأكثز & \\
\hline \multirow{2}{*}{0.137} & \multirow{2}{*}{348} & \multirow{2}{*}{1.491} & 0.684 & 3.96 & 130 & أقل من 0 & \multirow{2}{*}{ 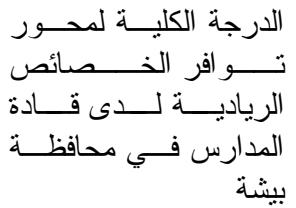 } \\
\hline & & & 0.818 & 3.83 & 220 & ه دور ات فأكثر & \\
\hline
\end{tabular}

محافظة بيشة وجميع مجالاته، مما يعني

تشير النتائج في جدول(ء ا ) إلى أن عدم وجود فروق ذات دلالة إحصائية عند قيمة ت" غير دالة احصائيا عند مستوى

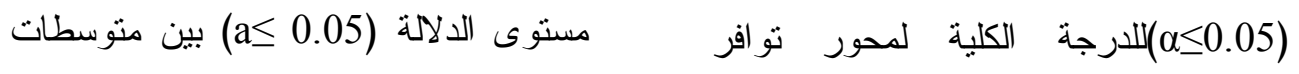

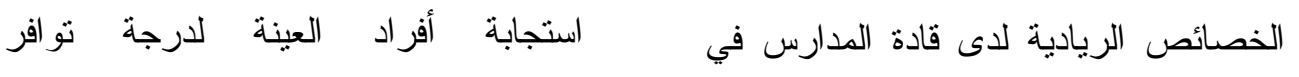


أفر اد العينة حول درجة تو افر الخصائص

الريادية لدى قادة المدارس في محافظة بيشة من وجهة نظر المعلمين التي تعزى لمتغير

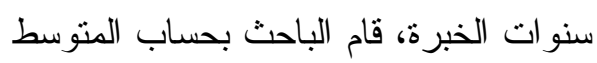

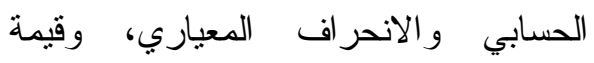
اختبار (ت) لاستجابات أفراد عينة الدراسة حول درجة نو افر الخصائص الريادية لدى لادى قادة المدارس في محافظة بيشة من وجهة نظر المعلمين، طبقا لمتغير سنوات الخبرة كما هو مبين بالجدول(0)
الخصائص الريادية لدى قادة المدارس في محافظة بيشة تعزى لاختلاف متغير الدورات التدريبية.

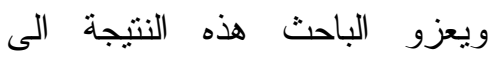
الوعي الكبير الذي يتمتع به المعلمون من

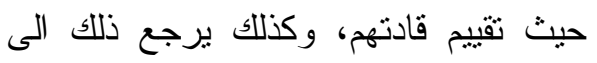
وضوح السمات و الخصائص لدى لون القادة وتقاربها على مستوى المدارس. ثالثاً: بالنسبة لمتغير سنوات مات الخبرة لحساب دلالة الفروق الإحصائية عند

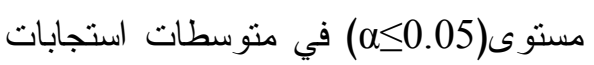

جدول (0 1) نتائج اختبار(ت) لالالة الفروق بين متوسطات استجابات أفراد عينة الدراسة على

دلالة الفروق لمجالات محور تو افر الخصائص الريادية لدى قادة المدارس في محافظة

بيشة والارجة الكلية للمحور تبعا لمتغير سنوات الخبرة

\begin{tabular}{|c|c|c|c|c|c|c|c|}
\hline مستوى الدلاية & الحرية & 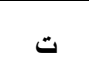 & الالمعراف & الحسابي & ن & سنوات الخبرة & المجالات \\
\hline \multirow[t]{2}{*}{0.552} & \multirow[t]{2}{*}{348} & \multirow[t]{2}{*}{0.595} & 0.788 & 4.00 & 140 & أقل من · ا سنو ات & \multirow{2}{*}{ الإبداع الأول: القدرة على } \\
\hline & & & 0.850 & 3.95 & 210 & • . سنو ات فأكثز & \\
\hline \multirow[t]{2}{*}{0.333} & \multirow[t]{2}{*}{348} & \multirow[t]{2}{*}{0.970} & 0.854 & 3.88 & 140 & أقل من · ا سنوات & \multirow{2}{*}{ المجال الثاني: المخاطرة } \\
\hline & & & 0.912 & 3.79 & 210 & ، أ سنو ات فأكثر & \\
\hline \multirow[t]{2}{*}{0.380} & \multirow[t]{2}{*}{348} & \multirow[t]{2}{*}{0.879} & 0.833 & 3.88 & 140 & أقل من · ـ سنو ات & \multirow{2}{*}{ المجال الثالث: الاستقلالية } \\
\hline & & & 0.794 & 3.80 & 210 & • ا سنو ات فأكثر & \\
\hline \multirow[t]{2}{*}{0.163} & \multirow[t]{2}{*}{348} & \multirow[t]{2}{*}{1.400} & 0.768 & 3.94 & 140 & أقل من · ا سنو ات & \multirow{2}{*}{ المجال الر ابع: المبادأة } \\
\hline & & & 0.901 & 3.81 & 210 & • . سنو ات فأكثر & \\
\hline \multirow[t]{2}{*}{0.402} & \multirow[t]{2}{*}{348} & \multirow[t]{2}{*}{0.839} & 0.756 & 3.95 & 140 & أقل من · ا سنو ات & \multirow{2}{*}{ 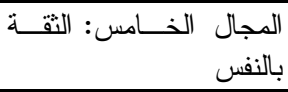 } \\
\hline & & & 0.834 & 3.88 & 210 & • ـ أسنو ات فأكثر & \\
\hline \multirow[t]{2}{*}{0.308} & \multirow[t]{2}{*}{348} & \multirow[t]{2}{*}{1.021} & 0.736 & 3.93 & 140 & أقل من · ا سنو ات & \multirow{2}{*}{ 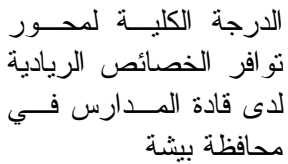 } \\
\hline & & & 0.796 & 3.84 & 210 & • ا سنوات فأكثر & \\
\hline
\end{tabular}


مستوى الدلالة (

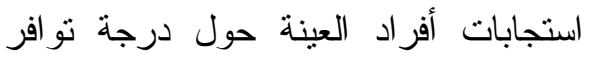
الخصائص الريادية لاى قادة المدارس في لئن محافظة بيثة من وجهة نظر المعلمين، و التي تعزى لمتغير مكتب التعليم التابعة له له لهنه

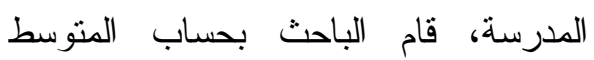

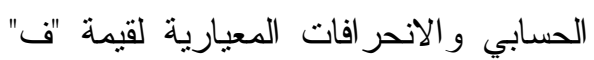
One -) طبقا لاختبار تحليل التباين الأحادي والحرانه (Way ANOVA

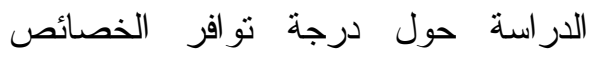
الريادية لدى قادة المدارس في محافظة بيشة، من وجهة نظر القادة المعلمين، و الني تعزى لمتغير مكتب التعليم التابعة له له نهين المدرسة.

حيث تم حساب المتوسطات الحسابية و الانحر افات المعيارية لدرجات اســتجابات

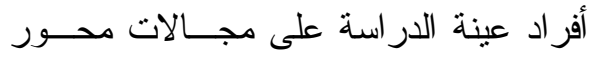
الخصائص الريادية لدى قادة المدارس فـي لـي محافظة بيشة والدرجة الكلية للمحور مـن وجهة نظر المعلمين، وفق متغيـر (مكتـبـ

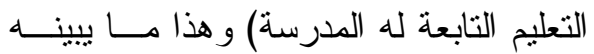

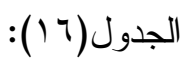

تشير النتائج في جدول (10) إلى أن قيمة ت" غير دالة احصائيا عند مستوى فئرول

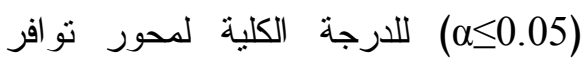
الخصائص الريادية لدى قادة المدارس في لهنه محافظة بيشة وجميع مجالاته، مما يعني عدم وجود فروق ذات دلالة إحصائية عند مستوى الدلالة(a $a .05$ a

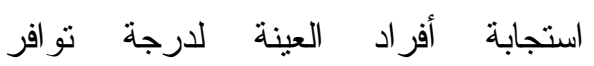
الخصائص الريادية لاى قادة المدارس في لنابه

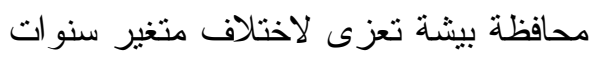
الخبرة. - مان ويعزو الباحث هذه النتائج الى أن

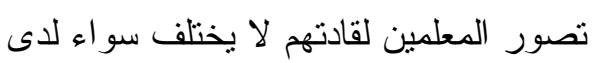

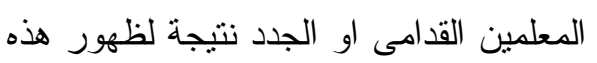
السمات و الممارسات ووضوحها. تتفق هذه النتائج مع دراسة مي

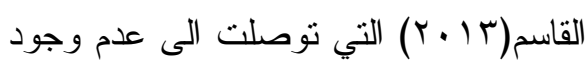
فروق ذات دلالة إحصائية في الخصائص الريادية تتعزى لاختلاف سنو ات الخبرة. رابعاً: بالنسبة لمتغير مكتب التعليم التابعة له المدرسة: لمعرفة دلالة الفروق الإحصائية عند 
جدول (7 1) المتوسطات الحسابية والاحر (فات المعيارية لمجالات محور الخصائص الريادية لاى قادة

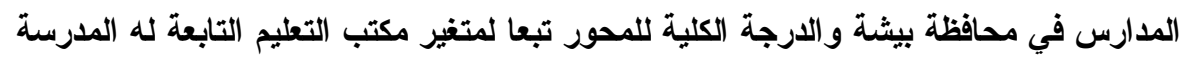

\begin{tabular}{|c|c|c|c|c|}
\hline الاتحراف المعياري & المتوسط الحسابي & 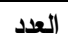 & المرحلة التعليمية & المجال \\
\hline 0.865 & 4.23 & 44 & مكتب الثنية & \multirow{6}{*}{ المجال الأول: القدرة على الإبداع } \\
\hline 0.594 & 4.23 & 23 & مكتب خيبر & \\
\hline 0.764 & 4.25 & 32 & مكتب النقيع & \\
\hline 0.853 & 3.80 & 187 & مكتب الوسط & \\
\hline 0.706 & 4.05 & 64 & مكتب ترج & \\
\hline 0.825 & 3.97 & 350 & المجموع & \\
\hline 0.899 & 4.19 & 44 & مكتب الثنية & \multirow{6}{*}{ المجال الثاني: المخاطرة } \\
\hline 0.692 & 3.99 & 23 & مكتب خيير & \\
\hline 0.784 & 4.02 & 32 & مكتب النقيع & \\
\hline 0.923 & 3.65 & 187 & مكتب الوسط & \\
\hline 0.791 & 3.92 & 64 & مكتب ثرج & \\
\hline 0.889 & 3.83 & 350 & المجموع & \\
\hline 0.844 & 4.08 & 44 & مكتب الثنية & \multirow{6}{*}{ المجال الثالث: الاستقلالية } \\
\hline 0.598 & 4.02 & 23 & مكتب خيير & \\
\hline 0.719 & 3.96 & 32 & مكتب النقيع & \\
\hline 0.831 & 3.71 & 187 & مكتب الوسط & \\
\hline 0.788 & 3.88 & 64 & مكتب ترج & \\
\hline 0.810 & 3.83 & 350 & المجموع & \\
\hline 0.810 & 4.12 & 44 & مكتب الثنية & \multirow{6}{*}{ المجال الر ابع: المبادأة } \\
\hline 0.578 & 4.12 & 23 & مكتب خيير & \\
\hline 0.745 & 4.09 & 32 & مكتب النقيع & \\
\hline 0.900 & 3.73 & 187 & مكتب الوسط & \\
\hline 0.800 & 3.85 & 64 & مكتب ترج & \\
\hline 0.852 & 3.86 & 350 & المجموع & \\
\hline 0.762 & 4.20 & 44 & مكتب الثنية & \multirow{6}{*}{ المجال الخامس: الثقة بالنفس } \\
\hline 0.552 & 4.15 & 23 & مكتب خيير & \\
\hline 0.763 & 4.11 & 32 & مكتب النقيع & \\
\hline 0.855 & 3.77 & 187 & مكتب الوسط & \\
\hline 0.686 & 3.91 & 64 & مكتب تزج & \\
\hline 0.804 & 3.91 & 350 & المجموع & \\
\hline 0.776 & 4.17 & 44 & مكتب الثتية & \multirow{6}{*}{ 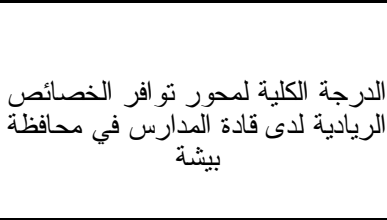 } \\
\hline 0.521 & 4.10 & 23 & مكتب خيير & \\
\hline 0.697 & 4.09 & 32 & مكتب النقيع & \\
\hline 0.807 & 3.73 & 187 & مكتب الوسط & \\
\hline 0.691 & 3.92 & 64 & مكتب ترج & \\
\hline 0.773 & 3.88 & 350 & المجموع & \\
\hline
\end{tabular}

ولتحديد فيما إذا كانت هذه الفروق

ذات دلالة إحصائية عند مسستوى الدلالـــة الإداء 0.05

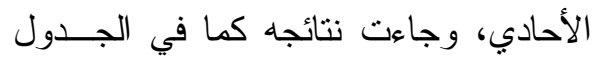
.(IV)
يتنين من الجدول(7 (1) وجود فروق

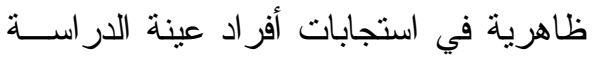

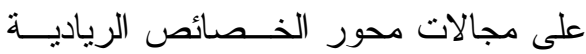

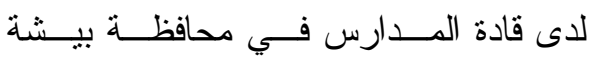

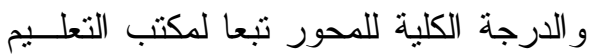
التابعة له المدرسة. 
جدول (IV) اختبار تحليل التباين الأحادي (One -Way Anova) للكشف عن دلالة الفروق لمجالات محور الخصائص الريادية لاى قادة المدارس في محافظة بيشة والدارجة

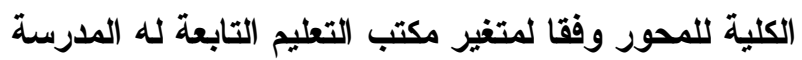

\begin{tabular}{|c|c|c|c|c|c|c|}
\hline مستوى & قيمة ف & المربعات & الحرجية & المربعوع & مصدر التباين & المجالات \\
\hline \multirow[t]{3}{*}{0.001} & \multirow[t]{3}{*}{4.884} & 3.181 & 4 & 12.7 & بين المجمو عات & \multirow{3}{*}{ المجال الأول: القدرة على الإبداع } \\
\hline & & 0.651 & 345 & 224.7 & داخل المجموعات & \\
\hline & & & 349 & 237.4 & الإجمالى & \\
\hline \multirow[t]{3}{*}{0.002} & \multirow[t]{3}{*}{4.487} & 3.412 & 4 & 13.6 & بين المجمو عات & \multirow{3}{*}{ المجال الثاني: المخاطرة } \\
\hline & & 0.760 & 345 & 262.3 & داخل المجموعات & \\
\hline & & & 349 & 275.9 & الإجمالي & \\
\hline \multirow[t]{3}{*}{0.032} & \multirow[t]{3}{*}{2.668} & 1.716 & 4 & 6.9 & بين المجموعات & \multirow{3}{*}{ المجال الثالث: الاستقلالية } \\
\hline & & 0.643 & 345 & 222.0 & داخل المجموعات & \\
\hline & & & 349 & 228.8 & الإجمالي & \\
\hline \multirow[t]{3}{*}{0.010} & \multirow[t]{3}{*}{3.393} & 2.396 & 4 & 9.6 & بين المجموعات & \multirow{3}{*}{ المجال الر ابع: المبادأة } \\
\hline & & 0.706 & 345 & 243.6 & داخل المجموعات & \\
\hline & & & 349 & 253.2 & الإجمالى & \\
\hline \multirow[t]{3}{*}{0.004} & \multirow[t]{3}{*}{3.953} & 2.469 & 4 & 9.9 & بين المجموعات & \multirow{3}{*}{ المجال الخامس: الثقة بالنفس } \\
\hline & & 0.625 & 345 & 215.5 & داخل المجموعات & \\
\hline & & & 349 & 225.4 & الإجمالى & \\
\hline \multirow[t]{3}{*}{0.002} & \multirow[t]{3}{*}{4.425} & 2.542 & 4 & 10.2 & بين المجمو عات & \multirow{3}{*}{ الخصائصة الكلية لمحور تو الدرية لدي فادة } \\
\hline & & 0.575 & 345 & 198.2 & داخل المجمو عات & \\
\hline & & & 349 & 208.4 & الإجمالى & \\
\hline
\end{tabular}

محافظة بيشة تعزى لاختلاف متغير مكاتب

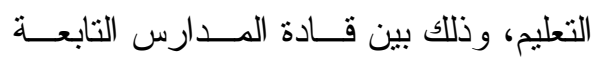

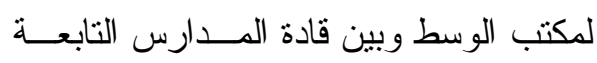
لكلا من مكتب الثثية، ومكتب خيير، ومكتب فئب

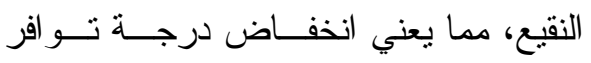

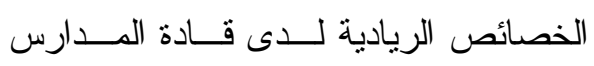

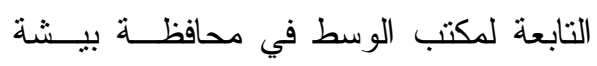

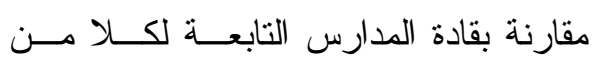
مكاتب الثثية وخيير و النقيع، كما في جدول
تشئر النائج في جدول(V) إلى أنى أن

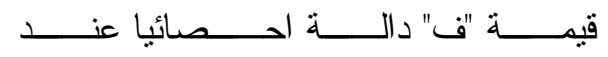

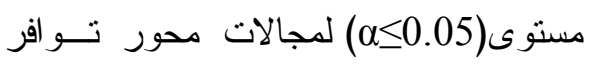

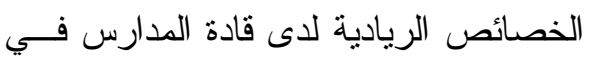

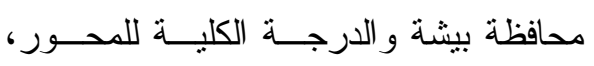
وللتعرف على اتجاه هذه الفروق نم إجــر اء اختبار شيفيه حيث تشير نتائج هذ الاختبــار

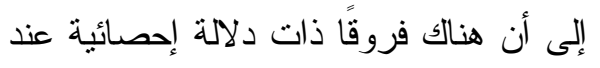

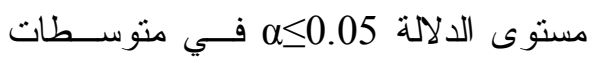

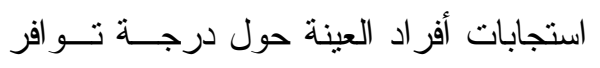
الخصائص الريادية لدى قادة المدارس فــي لردي 
جدول (1 1 ) اختبار شيفيه (Scheffe) للتعرف على اتجاه الفروق في مجالات محور

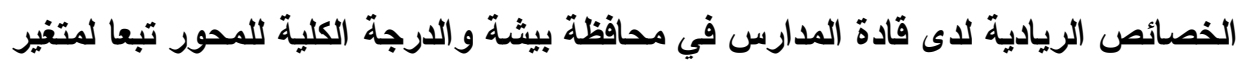

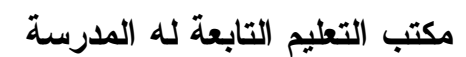

\begin{tabular}{|c|c|c|c|c|c|c|c|}
\hline مكتب ترج & الوستب & مكتب & خكتب & مكتب & الحسابي & المرحلة & 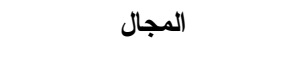 \\
\hline & & & & & 4.23 & مكتب الثثية & \multirow{5}{*}{ المجال الأول: القدرة على } \\
\hline & & & & & 4.23 & مكتب خيير & \\
\hline & & & & & 4.25 & مكتب النقيع & \\
\hline & & $-.444^{*}$ & $-.432^{*}$ & $-.428^{*}$ & 3.80 & مكتب الوسط & \\
\hline & & & & & 4.05 & مكتب ترج & \\
\hline & & & & & 4.19 & مكتب الثثية & \multirow{5}{*}{ المجال الثاني: المخاطرة } \\
\hline & & & & & 3.99 & مكتب خيير & \\
\hline & & & & & 4.02 & مكتب النقيع & \\
\hline & & $-.368 *$ & $-.333 *$ & $-.533 *$ & 3.65 & مكتب الوسط & \\
\hline & & & & & 3.92 & مكتب ترج & \\
\hline & & & & & 4.08 & مكتب الثثية & \multirow{5}{*}{ المجال الثالث: الاستقلالية } \\
\hline & & & & & 4.02 & مكتب خيير & \\
\hline & & & & & 3.96 & مكتب النقيع & \\
\hline & & $-.250 *$ & $-.304 *$ & $-.367 *$ & 3.71 & مكتب الوسط & \\
\hline & & & & & 3.88 & مكتب نرج & \\
\hline & & & & & 4.12 & مكتب الثثية & \multirow{5}{*}{ المجال الر ابع: المبادأة } \\
\hline & & & & & 4.12 & مكتب خيير & \\
\hline & & & & & 4.09 & مكتب النقيع & \\
\hline & & $-.357 *$ & $-.396 *$ & $-.396^{*}$ & 3.73 & مكتب الوسط & \\
\hline & & & & & 3.85 & مكتب ترج & \\
\hline & & & & & 4.20 & مكتب الثية & \multirow{5}{*}{ المجال الخامس: الثقة بالنفس } \\
\hline & & & & & 4.15 & مكتب خيير & \\
\hline & & & & & 4.11 & مكتب النقيع & \\
\hline & & $-.335^{*}$ & $-.372 *$ & $-.431 *$ & 3.77 & مكتب الوسط & \\
\hline & & & & & 3.91 & مكتب ترج & \\
\hline & & & & & 4.17 & مكتب الثية & \multirow{5}{*}{ الدصائصة الكلية لمحور تو الفر لادية لدادة } \\
\hline & & & & & 4.10 & مكتب خيبر & \\
\hline & & & & & 4.09 & مكتب النقيع & \\
\hline & & $-.351 *$ & $-.367 *$ & $-.431 *$ & 3.73 & مكتب الوسط & \\
\hline & & & & & 3.92 & مكتب ترج & \\
\hline
\end{tabular}


للالتزام التظظيمي لدى المعلمين بمدارس

ويعزو الباحث هذه النتيجة إلــى أن

محافظة بيشة من وجهة نظر المعلمين؟

مكتب الوسط يضم العديد مــن المــدارس

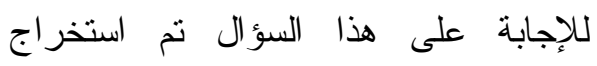

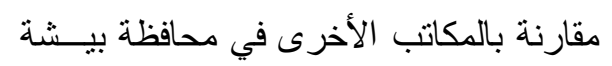

المتوسطات الحسابية و الانحر افات المعيارية

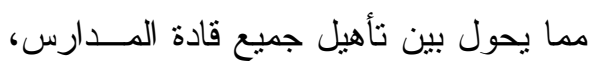

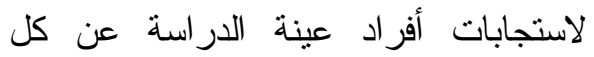

و هذا ما يفسر انخفاض درجة الخـصائص

مجال من المجالات وعلى الاستبانة ككل

الريادية لديهم بمجالاتها.

كما هو مبين في الجدول الآتي:

نتائج السؤال الثالث ومناقشتها وتفسيرها:

ما درجة تعزيز قادة المدارس

جدول (9 9 ) المتوسطات الحسابية والاتحر افات المعيارية لاستجابات أفر اد عينة الاراسة على دادي

كل مجال من مجالاتها وعلى الاستبانة ككل مرتبة تنازليا حسب المتوسطات الحسابية

\begin{tabular}{|c|c|c|c|c|c|c|}
\hline الممارسة & 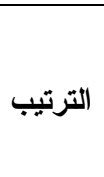 & المعياري & الحسابي & ن & 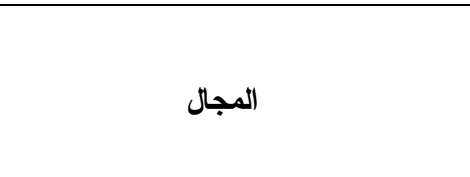 & المجال في الاستبانة \\
\hline 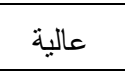 & 1 & 0.799 & 4.05 & 350 & المجال الثالث: المسؤولية تجاه المدرسة & 3 \\
\hline 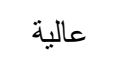 & 2 & 0.819 & 4.04 & 350 & المجال الأول: الالتز ام العاطفي & 1 \\
\hline 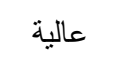 & 3 & 0.803 & 3.97 & 350 & المجال الثاني: الالتز ام المستمر & 2 \\
\hline 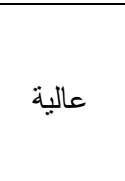 & & 0.810 & 3.99 & 350 & 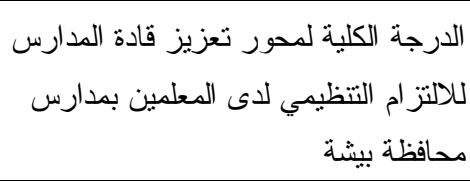 & \\
\hline
\end{tabular}

جميعها جاءت بدرجة عالية، حيــث تــراوح

يتضح من الجدول السابق (9 (1) أن

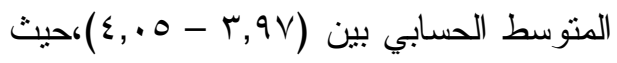

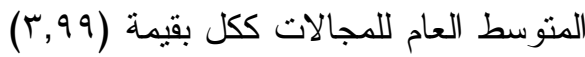

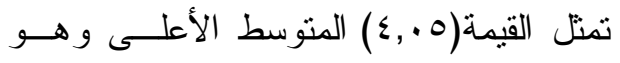

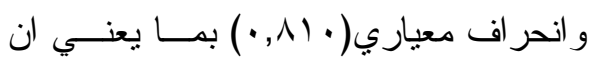

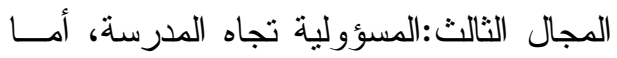

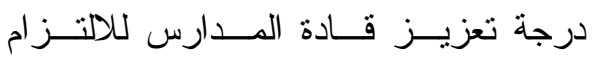

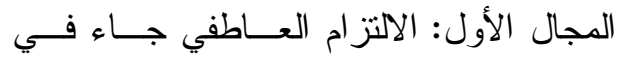

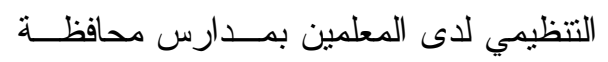

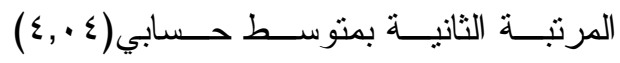

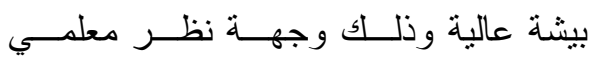

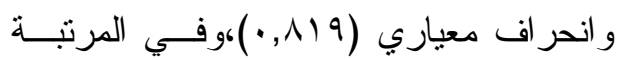

المدارس الحكومية بمحافظة بيـشة، حيــث

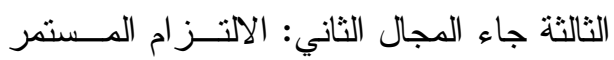

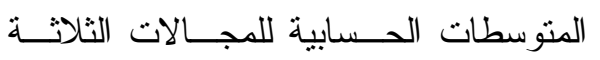


وجهة نظر هم كانت كبيرة. كمـــا تتفـق مــع

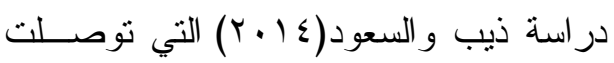

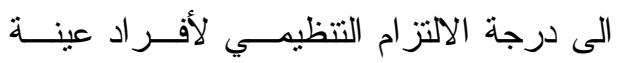

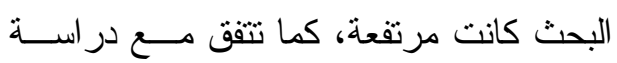

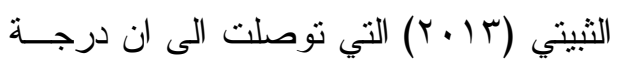
الالتز ام التتظيمي لــدى المعلمـين مرتفعـــة.

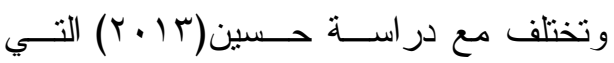

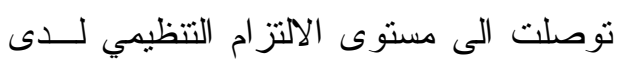
القادة الإداريين في الميدان المبحوث منوسط. وللتحليل المتعمق لبيانات الدراسة تــم

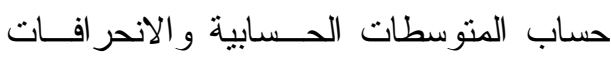
المعيارية لدرجة تعزيز قادة المدارس للالتز ام التظظيمي لدى المعلمين بمدارس محافظة بيشة على مستوى كل مجال من مجالات الاستبانة

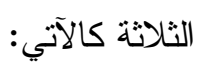
المجال الأول: الالتزام العاطفي

تم استخر اج المتوســطات الحـسابية والانحر افات المعيارية لاستجابات أفراد عينة الدراسة على مفردات المجال الأول " الالنز ام

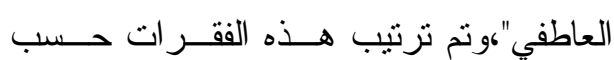

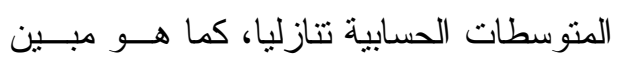
بالجدول الآتي:

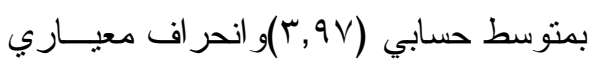

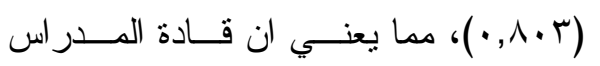

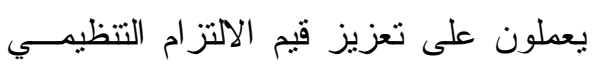

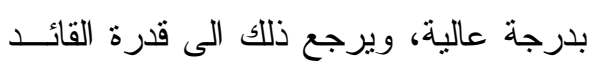
على القيام بمهامه وكذللك إدر اكـــه للــــوائح العمل المدرسي، من خلال ممارسات القادة

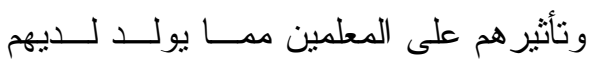

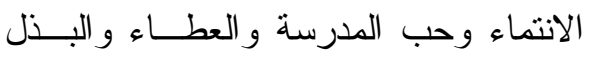

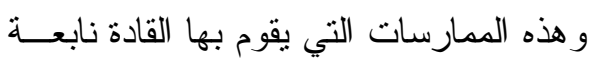
من الخصائص التي يمتلكونها، فالخصائص الريادية التي يمتلكها قادة المدر ساس تمكــنهم

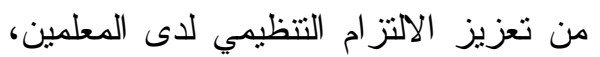

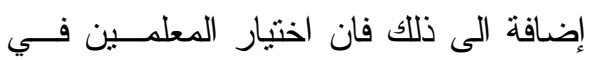

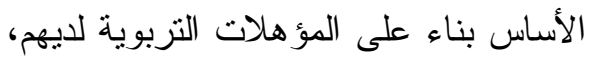

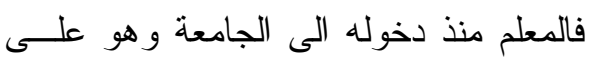

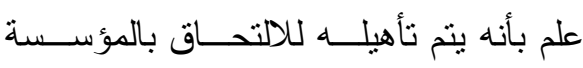

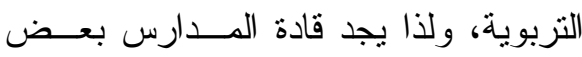

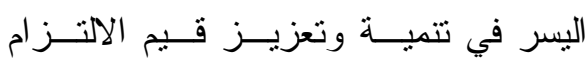

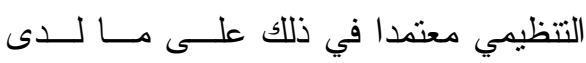
المعلمين من استعداد لذلك.

تتفق هذه النتائج مع دراسة الأشهب

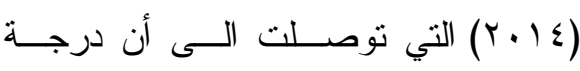
مستوى الالتز ام التنظيمي لدى المعلمين في

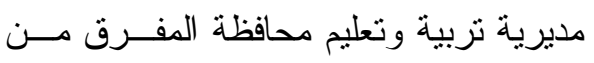


جدول (·r) المتوسطات الحسابية والاتحرافات المعيارية لاستجابات أفراد عينة الدراسة على فقزات مجال الالتز ام العاطفي مرتبة تنازليا حسب المتوسطات الحسابية

\begin{tabular}{|c|c|c|c|c|c|}
\hline 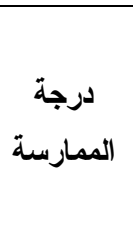 & الترتي & |الاحمرا & |العسابي & 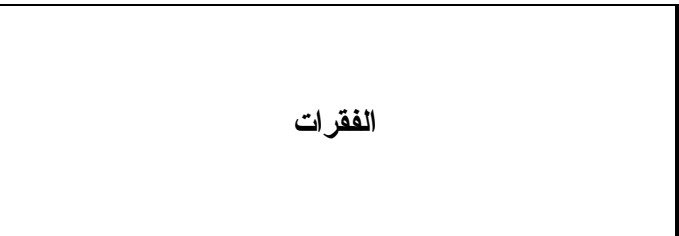 & رقة \\
\hline عالية جداً & 1 & 0.975 & 4.24 & حرصي أن أكون عضو أ فاعلاً في المدرسة. & 1 \\
\hline عالية & 2 & 0.980 & 4.11 & استعدادي لبذل مجهود أكبر من المطلوب لإنجاح عملي & 12 \\
\hline عالية & 3 & 1.010 & 4.053 & استمتاعي بالحديث عن عملي بالمدرسة التي أعمل بها & 2 \\
\hline عالية & 4 & 1.045 & 4.050 & مستوى إخلاصي للعمل بالمدرسة. & 10 \\
\hline عالية & 5 & 1.022 & 4.044 & شعوري بأنني جزء من المدرسة التي أعمل بها & 7 \\
\hline عالية & 6 & 1.008 & 4.043 & عند الانتماء لها. & 13 \\
\hline عالية & 7 & 1.025 & 4.042 & شعوري بأنني مرتبط عاطفيا المدرسة التي أعمل بها & 8 \\
\hline عالية & 8 & 1.080 & 4.03 & شعوري بالفخر و الاعتزاز كوني أحد أفراد المدرسة. & 6 \\
\hline عالية & 9 & 1.060 & 4.022 & شعوري كمعلم بالانتماء لمدرستي وكأنها بيتي. & 4 \\
\hline عالية & 10 & 1.054 & 4.021 & شعوري بالسعادة لأنني أعمل في الددرسة الني أعمل بها & 5 \\
\hline عالية & 11 & 1.038 & 3.99 & و كأنهوري مشكلانت المشاكل التي تو اجه الددرسة التي أعمل بها & 3 \\
\hline عالية & 12 & 1.060 & 3.95 & اعنبار وجودي في هذه المدرسة مؤشر اً لكفاءتي. & 9 \\
\hline عالية & 13 & 1.135 & 3.93 & بانتمائي للمدرسة الني أعمل بها. & 11 \\
\hline عالية & & 0.819 & 4.04 & الدرجة الكلية لمجال الالتز ام العاطفي & \\
\hline
\end{tabular}

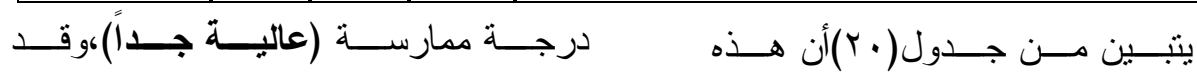

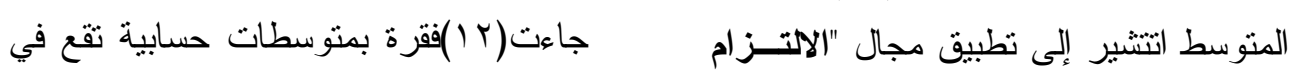

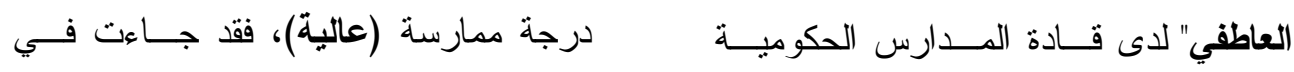

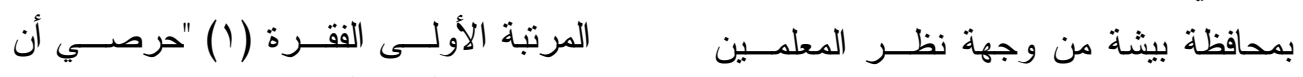

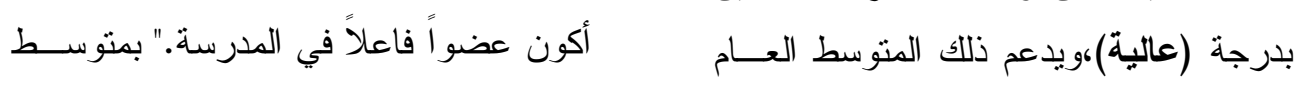

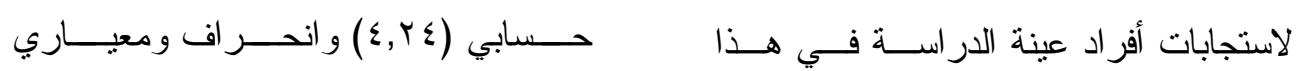

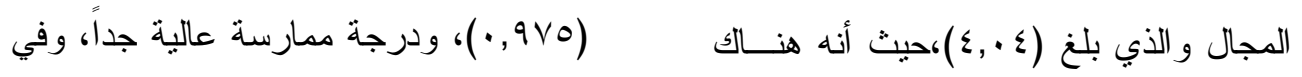

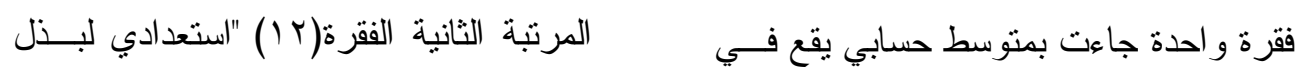




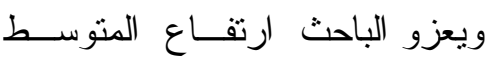

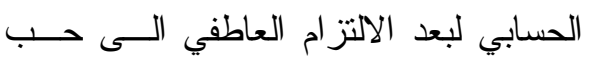

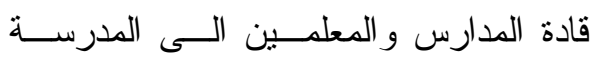

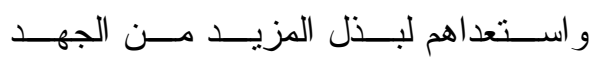

مقابل تحقيق نجاح أكبر للمدرســة،حيث ان

نجاح المدرسة هو نجاح لهم بطبيعة الحــال

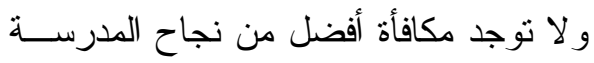

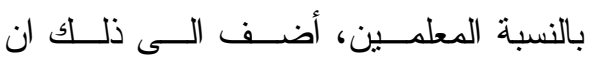

هنالك تجانس للتوجهات و الميول للمعلمـين

في ضوء الخلفية الثقافية الواحدة و الهــدف ولفول الو احد و المجتمع المدرسي برمته يعمل فــي

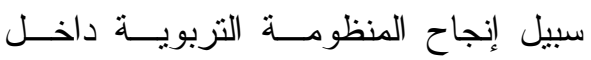

$$
\text { المدرسة. }
$$

المجال الثاني: الالتزام المستمر

تم استخر اج المتوسطات الحسـسابية

و الانحر افات المعيارية لاسـتجابات أفــر اد اد

عينة الدراســة علــى مفــردات المجـــال

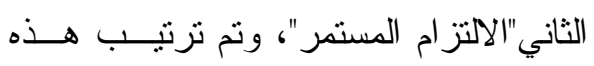

الفقرات حسب المتوسطات الحسابية تتازليا، كما هو مبين بالجدول الآتي:
مجهود أكبر من المطلوب لإنجاح عملـي"

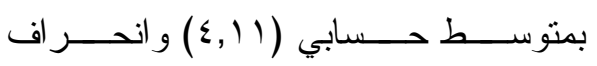

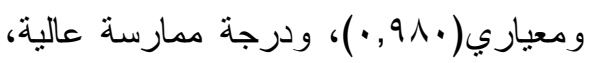

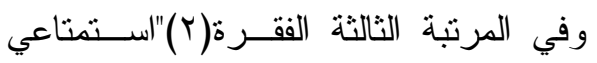
بالحديث عن عملي بالمدرسة التـي أعمـلـل

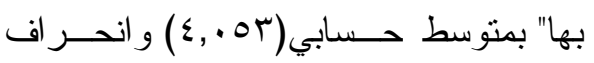
ومعيــاري (· (1, (1)، ودرجــة ممارســـة

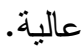

وفــي المرتبـــة الحاديـــة عــشر

الفقرة(ץ) "ثعوري بأن المشاكل التي تواجه

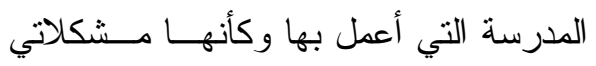

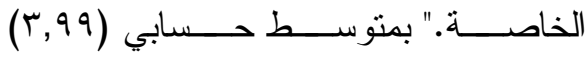

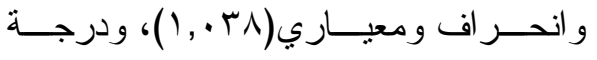

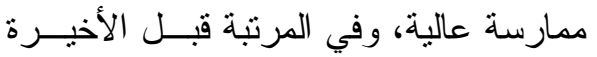
الفقرة(9)"اعتبار وجودي في هذه المدرســـة ونسة مؤشر اً لكفاعتي." بمتوسط حسـسابي(

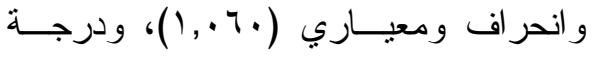
ممارسة عاليــة، وفــي المرتبـــة الأخيــرة

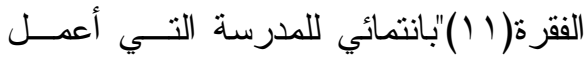
بها."بمنو ســط حسـسابي( ب

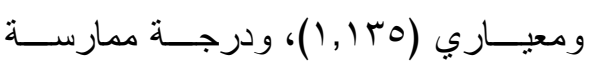

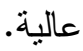




\section{جدول (1) المتوسطات الحسابية والاتحرافات المعيارية لاستجابات أفر اد عينة الدراسة}

على فقرات مجال الالتزام المستمر مرتبة تنازليا حسب المتوسطات الحسابية

\begin{tabular}{|c|c|c|c|c|c|}
\hline 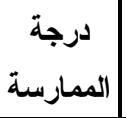 & الترتيب & | الاتحر اف & | المتوسطابي & 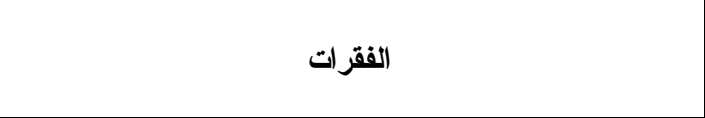 & رق الفقرة \\
\hline عالية & 1 & 0.960 & 4.16 & | تأييدي لبقاء و لاثي لمؤسستي التي أعمل بها. & 14 \\
\hline عالية & 2 & 0.955 & 4.05 & شهوري بأن على الأفر اد الولاء دائما للمنظمات التي يعملون & 20 \\
\hline عالية & 3 & 0.943 & 4.05 & استعدادي لبذل المزيد من الجهد من أجل الددرسة. & 25 \\
\hline عالية & 4 & 1.035 & 4.05 & الأخرى أتقادي أن قيم مهنة التذريس أكثر أهية مسن قـيم المهـن & 22 \\
\hline عالية & 5 & 1.013 & 4.02 & أن عملي بالددرسة بساعدني على إبراز ما لدي من قدرات. & 26 \\
\hline عالية & 6 & 1.000 & 3.97 & أدركي بأن الددرسة الني أعمل بها من أفضل المدارس. & 15 \\
\hline عالية & 7 & 1.030 & 3.96 & مشاركتي في اللجان التي تقدم خدمة لصسالح المدرسة. & 17 \\
\hline عالية & 8 & 1.009 & 3.96 & شعوري بالسعادة في بقائي و استمر اري بمدرستي. & 19 \\
\hline عالية & 9 & 1.063 & 3.95 & شعوري بارتياح لمناخ العمل السائد في المدرسة. & 18 \\
\hline 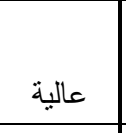 & 10 & 1.073 & 3.90 & بقائي وتمسكي بالعمل في المدرسة سبعمل على إكسابي الكثير & 23 \\
\hline عالية & 11 & 1.066 & 3.90 & المادي. رغبتي في الاستمر ار بالتدريس بغض النظر عـن المــردود & 16 \\
\hline عالية & 12 & 1.056 & 3.89 & شعوري بأن مهنة التدريس تلبي طموحاتي المستقبلية. & 21 \\
\hline عالية & 13 & 1.110 & 3.79 & عمل أفضل. عركي لمدرستي التي أعمل بها حتى وأن حصلت علـى & 24 \\
\hline عالية & & 0.803 & 3.97 & الدرجة الكلية لمجال الالتز ام المستمر & \\
\hline
\end{tabular}

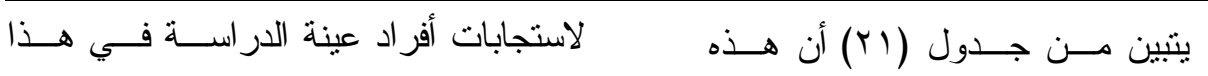

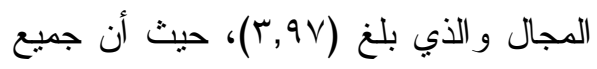

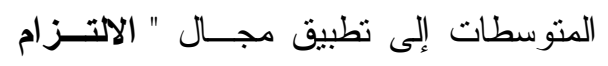

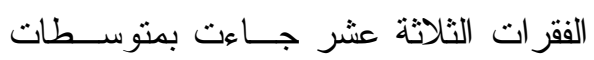

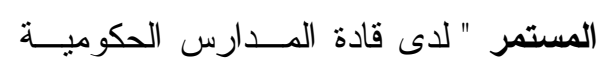

بمحافظة بيشة من وجهة نظــر المعلمـين لمسابية تقع في درجة ممارسة (عالية)، فقد

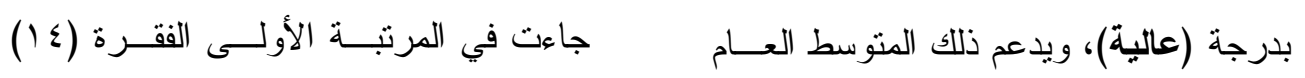


المعلمين يضعون في اعتبــار هم المكاســـب

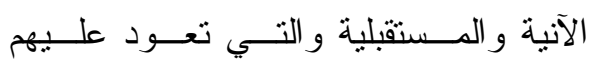

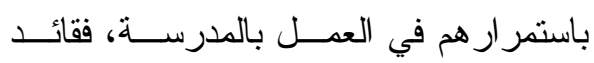

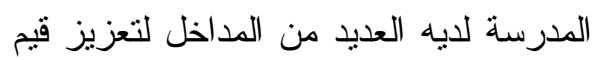

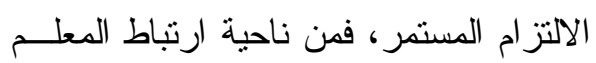

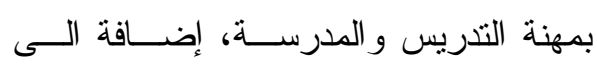
الاحساس الادبي لدى المعلمين في البقاء في

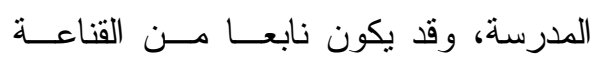
الداخلية للمعلمين انفسهم، وكذلك من الخلفية الأخلاقية للمعلمين تجاه مهنة التدريس، ومن الناحية الأخرى الدافع المادي الذي يجعـــل

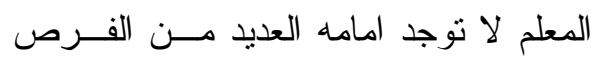

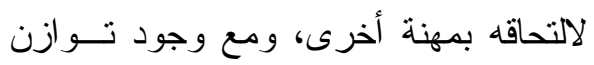
بين هاتين العنصرين وبوجود الخــصائص الريادية و المهارات القيادية كذل ذلك يسهل وبن من قدرة قادة المدراس على تعزيز الالتز ام

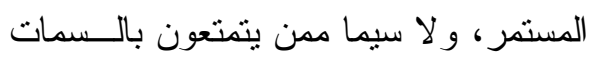

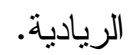

\section{المجال الثالث: المسؤولية تجاه المدرسة}

تم استخر اج المتوسطات الحسابية و الانحر افات المعيارية لاستجابات أفراد عينة الدراسة على مفردات المجال الثالث"

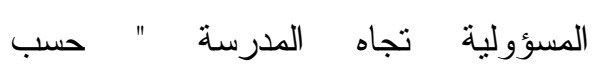

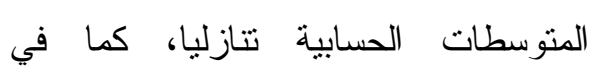
الجدول الآتي: - ات
"تأييدي لبقاء و لائي لمؤسستي التي أعمـلـل

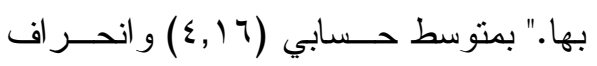
و معياري (•99, •))، ودرجة ممارسة عالية،

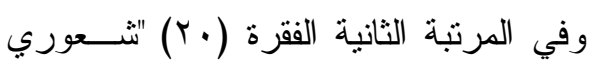

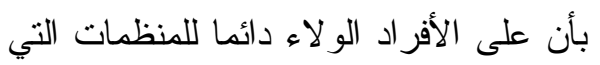

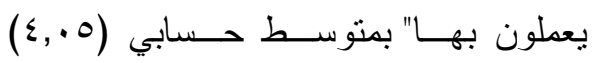
و انحر اف ومعيــاري (900, ·))، ودرجــة ممارسة عالية، وفي المرنبة الثالثة الفقــرة ودرة

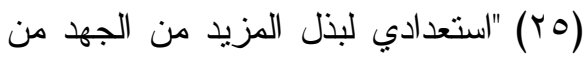
أجل المدرسة." بمتوســـ حسـسابي (0., عـ

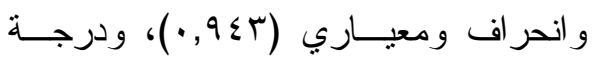

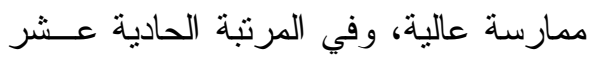
الفقــرة (7 1 ) "رغبتــي فــي الاســتمر ار بالتدريس بغض النظر عن المردود المادي."

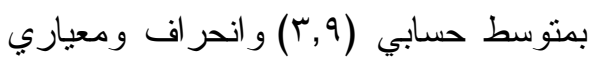

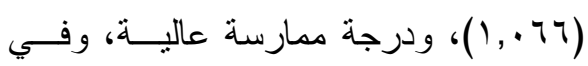

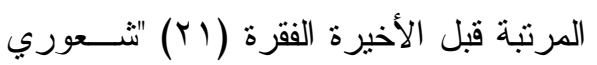

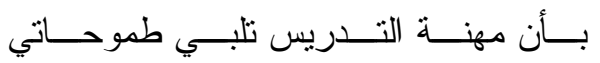

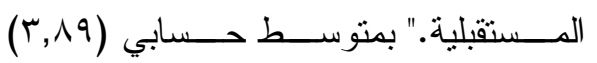

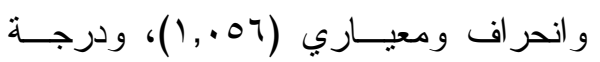
ممارسة عالية، وفي المرتبة الأخيرة الفقرة

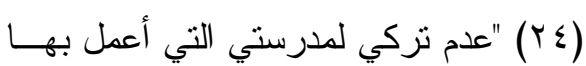

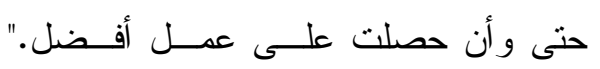

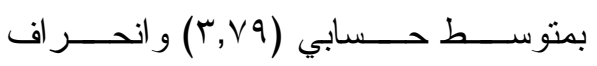
ومعياري (· ل1, (1))، ودرجة ممارسة عالية. ويرى الباحث حصول مجال الالتز ام

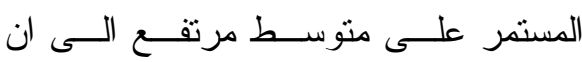




\section{جدول (Yr) المتوسطات الحسابية والاتحرافات المعيارية لاستجابات أفر اد عينة الدراسة}

\section{على فقر ات مجال المسؤولية تجاه المدرسة مرتبة تنازليا حسب المتوسطات الحسابية}

\begin{tabular}{|c|c|c|c|c|c|}
\hline 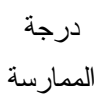 & التزتي & 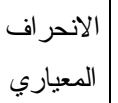 & 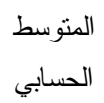 & 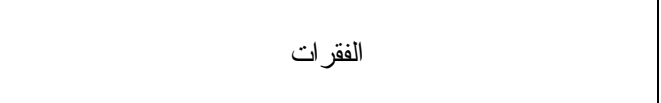 & 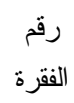 \\
\hline عالية & 1 & 0.987 & 4.14 & محافظتي على سمعة الددرسة لدى المجتمع. & 34 \\
\hline عالية & 2 & 0.971 & 4.12 & شعوري بو اجبي تجاه نجاح المدرسة التي أعمل بها. & 37 \\
\hline عالية & 3 & 1.006 & 4.12 & حرصي على نجاح لددرسة في أداء مهماتها. & 35 \\
\hline عالية & 4 & 1.024 & 4.12 & محافظتي على أوقات العطل في المدرسة التي أعمل بها. & 32 \\
\hline عالية & 5 & 1.058 & 4.08 & محافظتي على الممتلكات الخاصة بالمدرسة. & 31 \\
\hline عالية & 6 & 0.995 & 4.07 & اهتمامي بالحصول على المعلومات ذات الفائدة للمدرسة. & 38 \\
\hline عالية & 7 & 0.990 & 4.07 & مبادرتي في تقديم مقترحات لنظوير الددرسة. & 27 \\
\hline عالية & 8 & 0.949 & 4.04 & أعمل فيها وقيمها. بين أهدافي وقيمي وأهداف الددرســـة التـي & 36 \\
\hline عالية & 9 & 0.995 & 4.04 & بذل قصارى جهدي لتحقيق أهداف الددرسة. & 28 \\
\hline عالية & 10 & 1.042 & 4.01 & محافظتي على تطبيق اللو ائح و القو انين الخاصة بالمدرسة. & 33 \\
\hline عالية & 11 & 0.984 & 4.00 & تفاعلي مع تحفيز المدرسة لأقدم أفضل أداء للعمل. & 29 \\
\hline عالية & 12 & 1.047 & 3.96 & شعوري بأن ضو ابط العطل الحالية نساعدني على التميز فـي & 40 \\
\hline عالية & 13 & 1.024 & 3.95 & مستوى التطابق بين قىمي وقىم المدرسة التي أعمل بها. & 39 \\
\hline عالية & 14 & 1.050 & 3.92 & تقبلي لأنظمة المدرسة المتعلقة بالمعلمين. & 30 \\
\hline \multicolumn{2}{|l|}{ عالية } & 0.799 & 4.05 & \multicolumn{2}{|l|}{ الدرجة الكلية لمجال المسؤولية تجاه المدرسة } \\
\hline
\end{tabular}

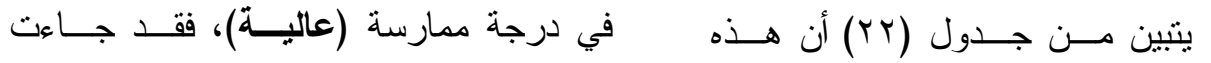

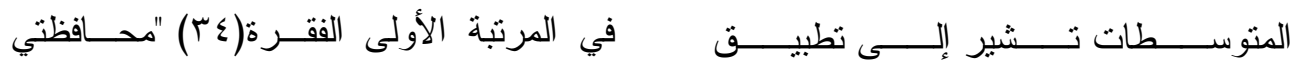

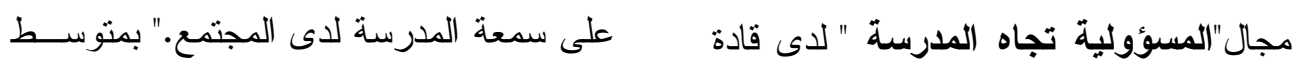

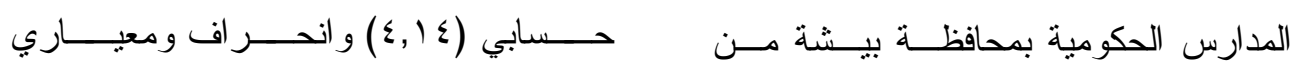

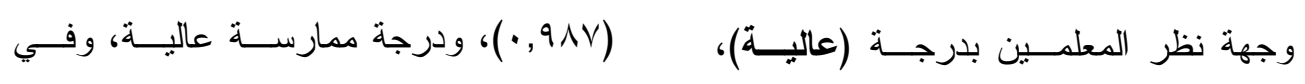

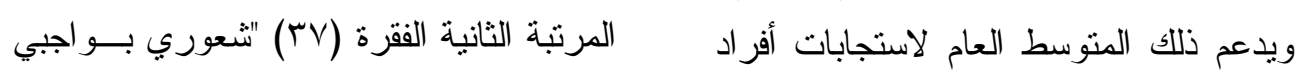

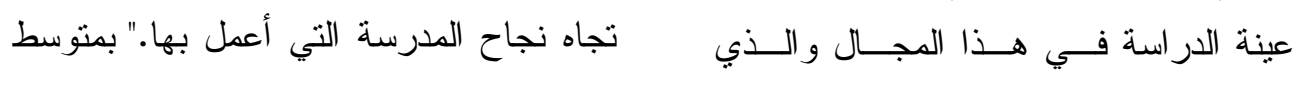

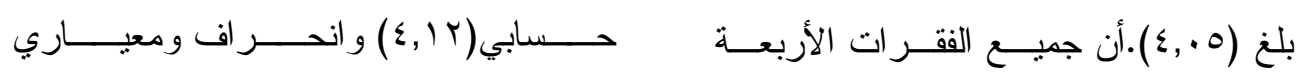

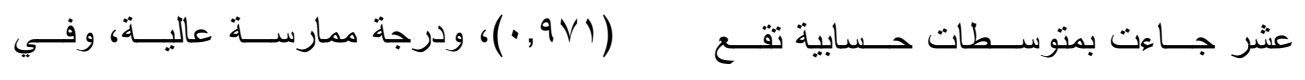


المدرسة، وكل ذللك يعـزز مــن مـسؤولية المعلمين تجاه المدرسة.

كما يمكن تفسير ذلك الى طبيعة بيئــة

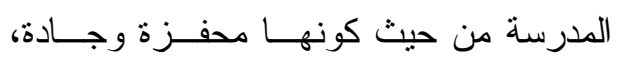

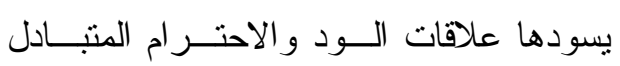

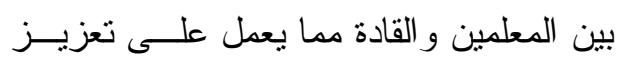
المسؤولية تجاه المدرسة وأوجد فيهم الهمـــة

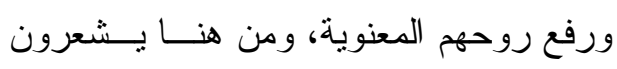
بالثقة بالنفس و الاستقر ار ومن ثم الانتماء. نتائج السؤال الخــامس ومناقـشتها

وتفسيرها:

هل توجد علاقة ارتباطية ذات دلالــــة

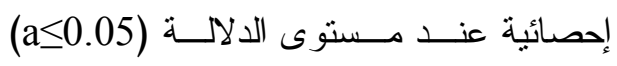
بين تو افر الخصائص الرياديــة لــدى قــادة المدارس بمحافظة بيـشة وتعزيــز الالتــز ام

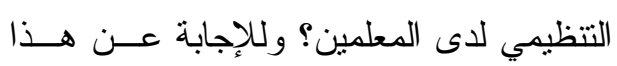

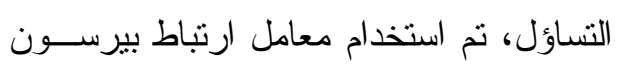

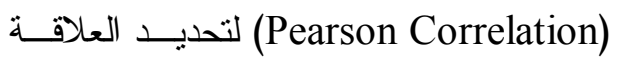
بين نو افر الخصائص الرياديــة لــدى قـــادة المدارس بمحافظة بيـشة وتعزيــز الالتــز ام التنظيمي لاى المعلمين من وجهة نظر معلمي المدارس، و الجدول التالي يوضح ذلك.

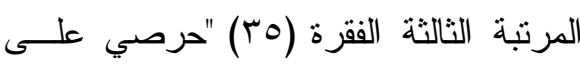

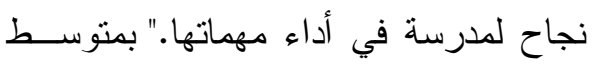

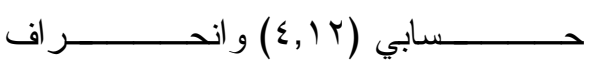

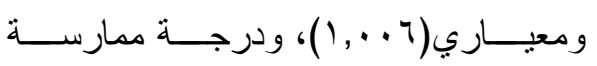

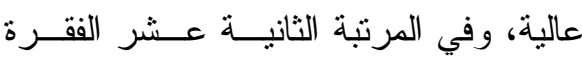

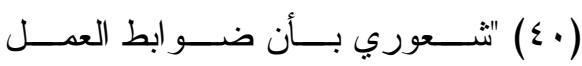

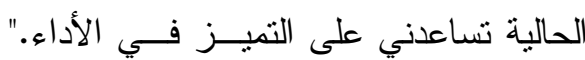

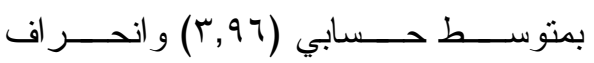
ومعياري (V乏 • , , )، ودرجة ممارسة عالية،

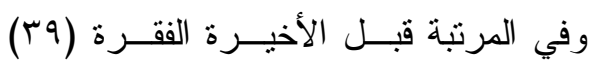
"مستوى النطابق بين قىمي وقىم المدرسة

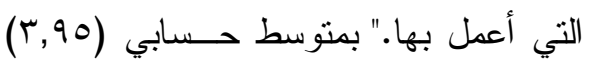

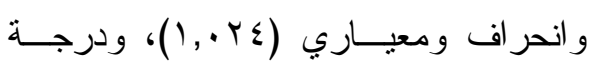

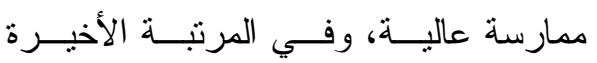

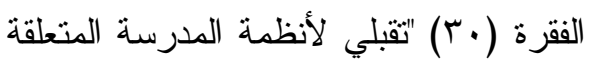

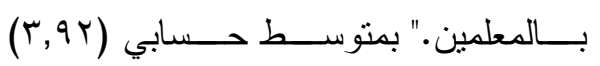

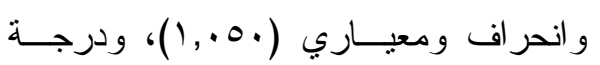
ممارسة عالية. ويعز و الباحث هــــه النتــائج الــى

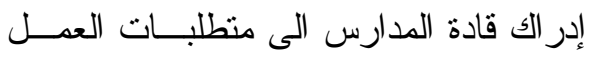
المدرسي و المسؤوليات، ومن ثم القدرة على

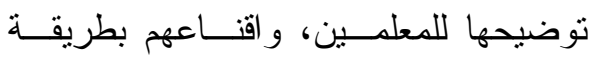
تطبيقها، و العمل بوجبها، وترسيخ المبــادئ

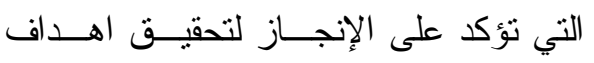


جدول (ج r) معامل ارتباط بيرسون (Pearson Correlation) للتعرف على العلاقة بين مجالات الخصائص الريادية لاى قادة المدارس بمحافظة بيثة ومجالات تعزيز

\begin{tabular}{|c|c|c|c|c|}
\hline \multicolumn{5}{|c|}{ الالتزام التنظيمي للى المعلمين } \\
\hline 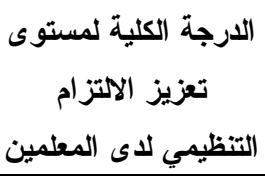 & الجسؤولية & 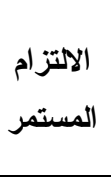 & العاطفي ام & المجالات المجات \\
\hline $.725^{* *}$ & $.668^{* *}$ & $.702^{* *}$ & $.740^{* *}$ & القدرة على الإبداع \\
\hline $.736^{* *}$ & $.672^{* *}$ & $.707^{* *}$ & $.742^{* *}$ & الهخاطرة \\
\hline $.689^{* *}$ & $.652^{* *}$ & $.688^{* *}$ & $.706^{* *}$ & الاسنقلالية \\
\hline $.753^{* *}$ & $.719^{* *}$ & $.750^{* *}$ & $.783^{* *}$ & 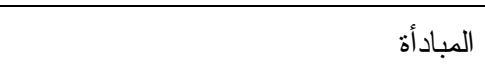 \\
\hline $.785^{* *}$ & $.716^{* *}$ & $.772^{* *}$ & $.797^{* *}$ & الثقة بالنفس \\
\hline $.798^{* *}$ & $.741^{* *}$ & $.783^{* *}$ & $.815^{* *}$ & 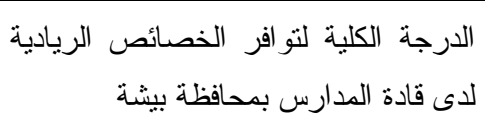 \\
\hline
\end{tabular}
* * * دالة إحصائيًا عند مستوى دلالة

سو اء في البقاء في المدرسة التي ينتمي لهــا

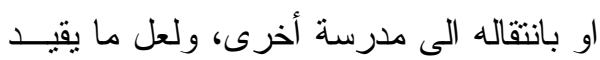
عمليات التتقل بين المــدارس المتقاربـــة ان مناخ الحقل التزبوي منتشابهة ونمطي الى حد لين

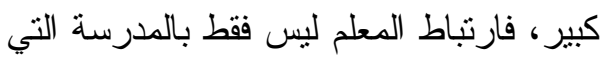

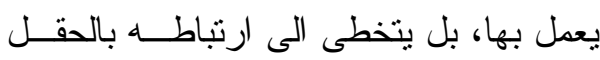

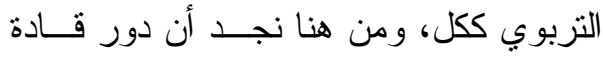

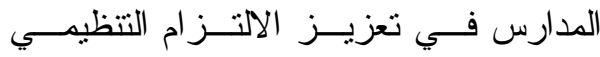
للمعلمين يرجع الى قدرة قائد المدرسة فــي لـي

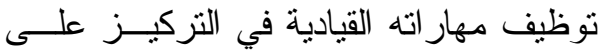

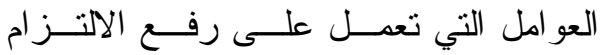
التنظيمي، وهو ما يظهر جليا مــن خــلال النتائج تبين ان السمات الريادية لــدى قـــادة المدارس جاء بدرجة مرتفعة ومن هنا ينتين
من خلال جدول(Y9) يتضح ان قـيم

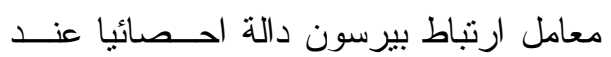
مستوى معنوية ا.,. . وذلك لجميع العلاقات

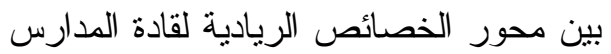

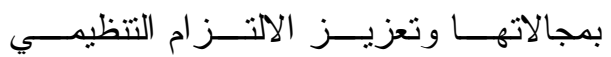

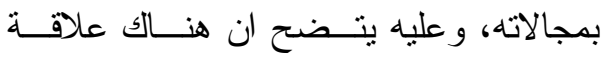

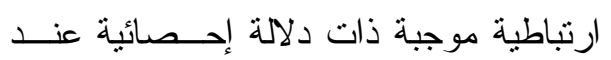
مستوى الدلالـــة (a $a .05$ a

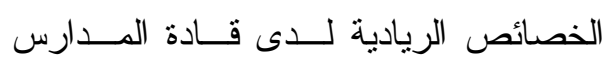
بمحافظة بيشة وتعزيز الالثز ام التتظيمي لدى لرى لاديه

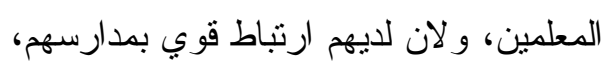

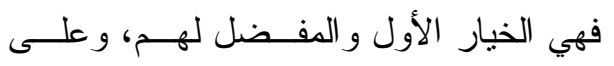

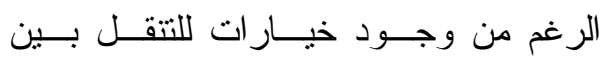
المدارس، فان القرار هنا يرجع للمعلم نفـســ لرجه 
نتائج الدراسة والتوصيات أولاً: ملخص نتائج الدراسة التوصيات

أن درجة نو افر الخصائص الرياديــة

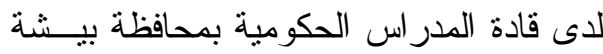
عالية وذلك من وجهة نظر معلمي المدارس

الحكومية بمحافظة بيشة.

انخفاض درجة تـــوافر الخــصائص

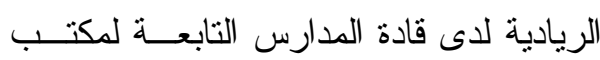

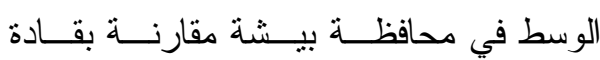
المدارس التابعة لكلا من مكاتب الثثية وخيير و النقيع.

ان درجة تعزيـز قــادة المــدارس

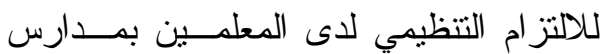

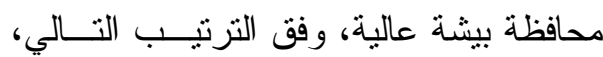
حيث جاء فــي المقدمــة المـسؤولية تجـــاه المدرسة، يليه الالتز ام العاطفي، ثم الالتــز ام

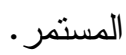

عدم وجود فروق ذات دلالة إحصائية

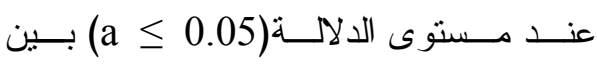
متوسطات استجابة أفر اد العينة حول مستوى

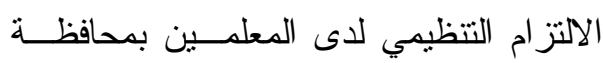
بيشة تعزي لمتغير المرحلة التعليمية توجد علاقة ارتباطيــة موجبــة ذات دلالـــة إحــصائية عنــد مـستوى الدلالهــة (a ب 0.05$)$

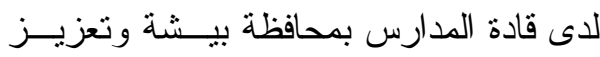
الالتز ام التنظيمي لدى المعلمين.
ان دور قادة المدارس في تعزيــز الالتــز ام التتظيمي للمعلمين مرتبط بخصائص وسمات القادة بدرجة كبيرة.

كما يعزو الباحث وجود هذه العلاقــة الى انه كلما توفرت في المدرسة الممارسات

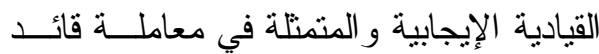

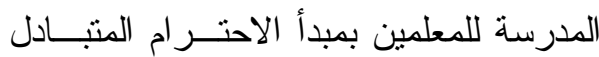

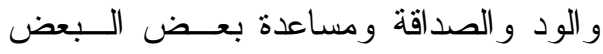
وامتلاكك روح المبـادأة ومــنح الاســنقلالية للمعلمين وتعزيز الثقة بالنفس للمعلمين وقدرة

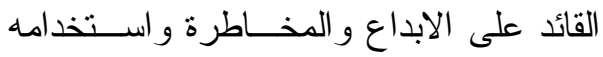
لوسائل التقنية في حل المشكلات وتوظيفهـا

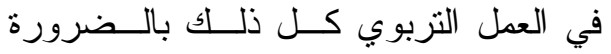
سيؤدي الى تعزيز الالتز ام التنظيمي للمعلمين

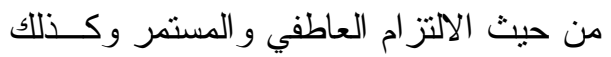

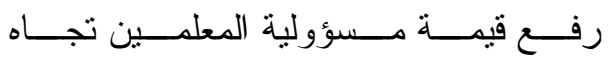
المدرسة . وتتفق هــــه النتــائج مـــع دراســـة

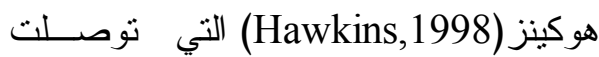
الى وجود علاقة إيجابية بين كل من مستوى الالتزام التتظيمي وخصائص المنظمة، تتفق

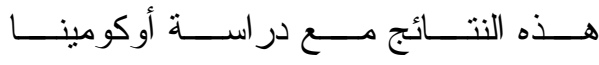
(Okhomina , 2010) أن للسمات السيكولوجية دور إيجـابي فـي تئي التأثير على تعزيز المواقف الريادية للأفر اد.

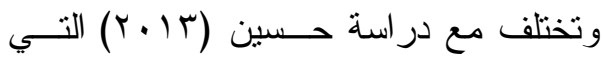
توصلت الى ضعف أنز للخصائص الريادية على الالتز ام التتظيمي لدى عينة الدراسة. 


$$
\text { قبل حدوثها. }
$$

- تعزيز وتتمية شعور المعلمين بارتباطهم بالمدرسة - تعزيــز شـــور المعلمـين بارتبــاطهم بالمدرسة. - على قادة المدارس العمل علــى جعـل

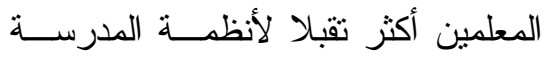
المتعلقة بالمعلمين. - على قادة المدارس ان بدفعوا المعلمــين بــين

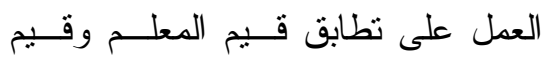

$$
\text { المدرسة. }
$$

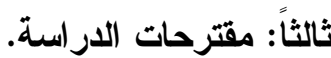
- تكر ار هــــه الدراســة علـــى منــاطق

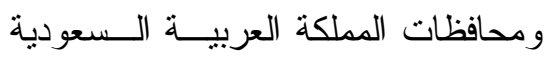
المختلفة.

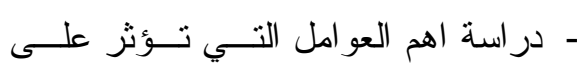
الخصائص الريادية لدى قادة المدارس. - العمل على اهم العوامل التي ترفع مــن مسنوى الالتز ام التنظيمي لدى المعلمين.

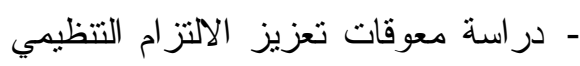
لدى المعلمين. - دراسة درجة تو افر الخصائص الريادية وعلاقتها بطرق اختبار قادة المدارس.

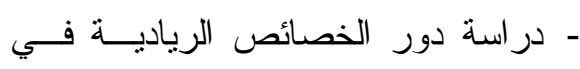
نجاح الإدارة المدرسية. - در اسة العلاقة بين الخصائص الرياديــة لاى قادة المدارس و النمط القيادي لديهم.
ثانياً: توصيات الاراسة.

- التزكيز في طرق اختيار قادة المــدارس

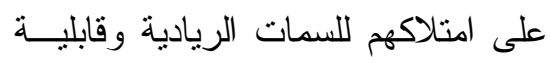
التطوير و التتمية المهنية.

- العمل على تعزيز الخــصائص الريــادة

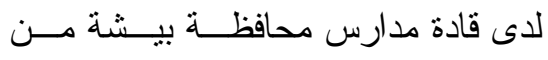

$$
\text { خلال الدور ات وورش العمل. }
$$

- ضرورة التأكيد على الخصائص الريادية

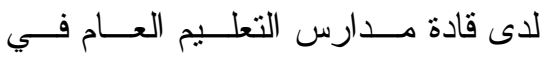

$$
\text { المملكة. }
$$

- ضرورة تطوير بــرامج التـدريب أولا

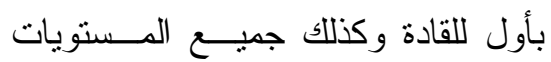

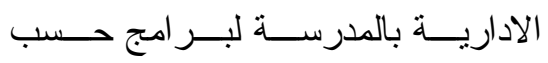

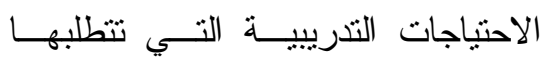

$$
\text { المرحلة. }
$$

- ـ إقامة ندوات على مـسنتوى المحافظـــة

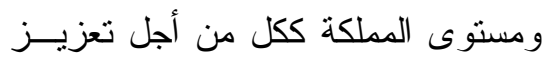

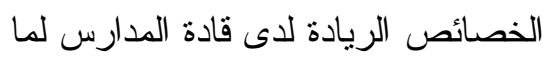

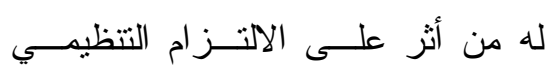
للمعلمين.

- حث قادة المدارس على إيجاد أســاليب جديدة لتتفيذ مختلف المهام.

- - بث روح المغامرة و المخاطرة المدروسة

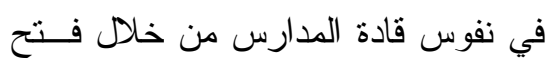

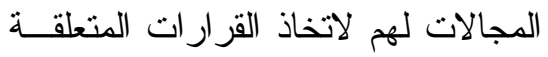
بالمدرسة.

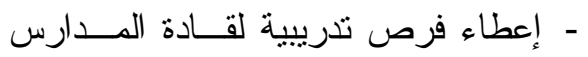
لتدريبهم للتعامل مع الازمات و التتبؤ بها لثرايها 
منشورة)، جامعــة أم القــرى، مكـــة

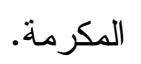

0. حامد، مهند (2007). نحو سياســات

لتعزيز الريادة بين الثباب في الضفة

الغربية وقطاع غزة. معهــــ أبحــاث

الــسياسات الاقتـــصادية الفلــسطيني

(ماس)، القدس ور ام الله، فلسطين.

7. حسين، قيس إبـر اهيم (2013). دور

الخصائص الريادية في تعزيز الالتزام

التنظيمي: دراسة اســنطلاعية لآراء

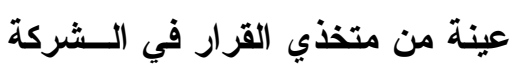

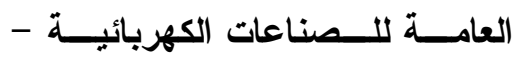

محافظة ديــالى، العــراق. (رســالة

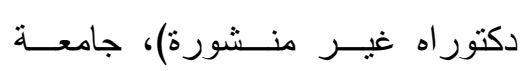

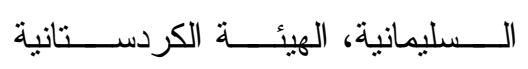

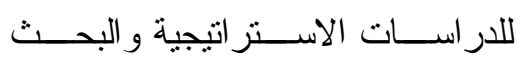

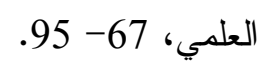

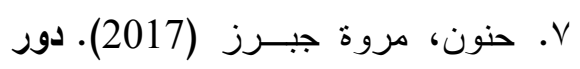

القوة التنظيمية في تعزيــز الالتــزام

التنظيمي لـــى الأفــر اد العـاملين.

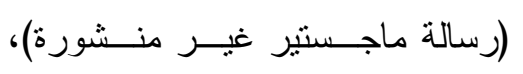

$$
\text { جامعة القادية، العر اق. }
$$

^. حو اس، أميرة محمد رفعت. (2003).

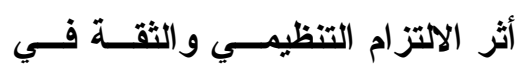

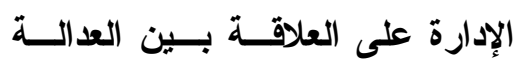

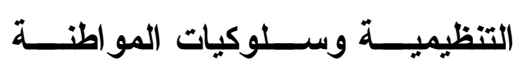

بالتطبيق علــى البنــوك التجاريـــة.

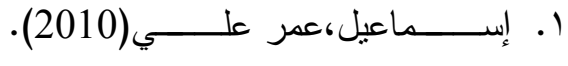

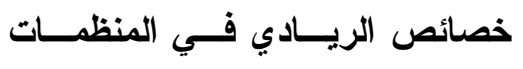

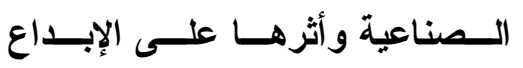

التقتي:در اسة حالة في الثركة العامة

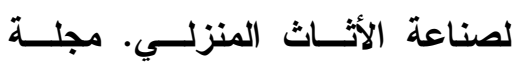

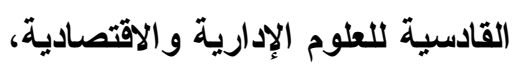

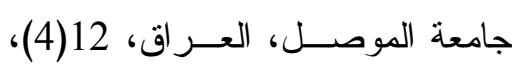
.91-66

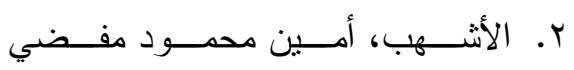

(2014). أثر البرامج التدريبية فـي الامي

الالتزام التظظيمي لاى المعلمين فـي التي

مديرية تربية وتعليم محافظة المفرق.

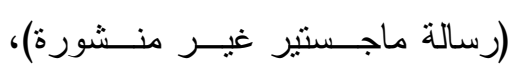
جامعة آل البيت، الأردن.

r. بالأطرش، سميرة (2011). الالتــزام

التنظيمي وعلاقته بالأداء الــوظيفي:

در اسة ميدانية لاى عينة من مربيــات

رياض الأطفال بو لاية ورقلة. (رسالة

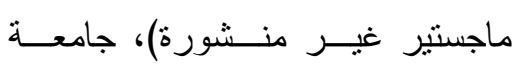

قاصدي مرباح، ورقلة، الجزائر .

ع. الثبيتي، سلطان بــن سـعود حامـــ

(2014). ممارسة مــدير المدرســة لونة

لإدارة التغييــر وعلاقتـــهـ بــالالتز ام

التنظيمي للمعلمين بالمدارس الثانوية

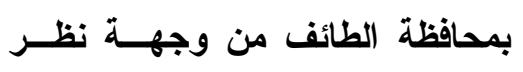

المعلمين. (رســالة ماجسـتير غيــر 


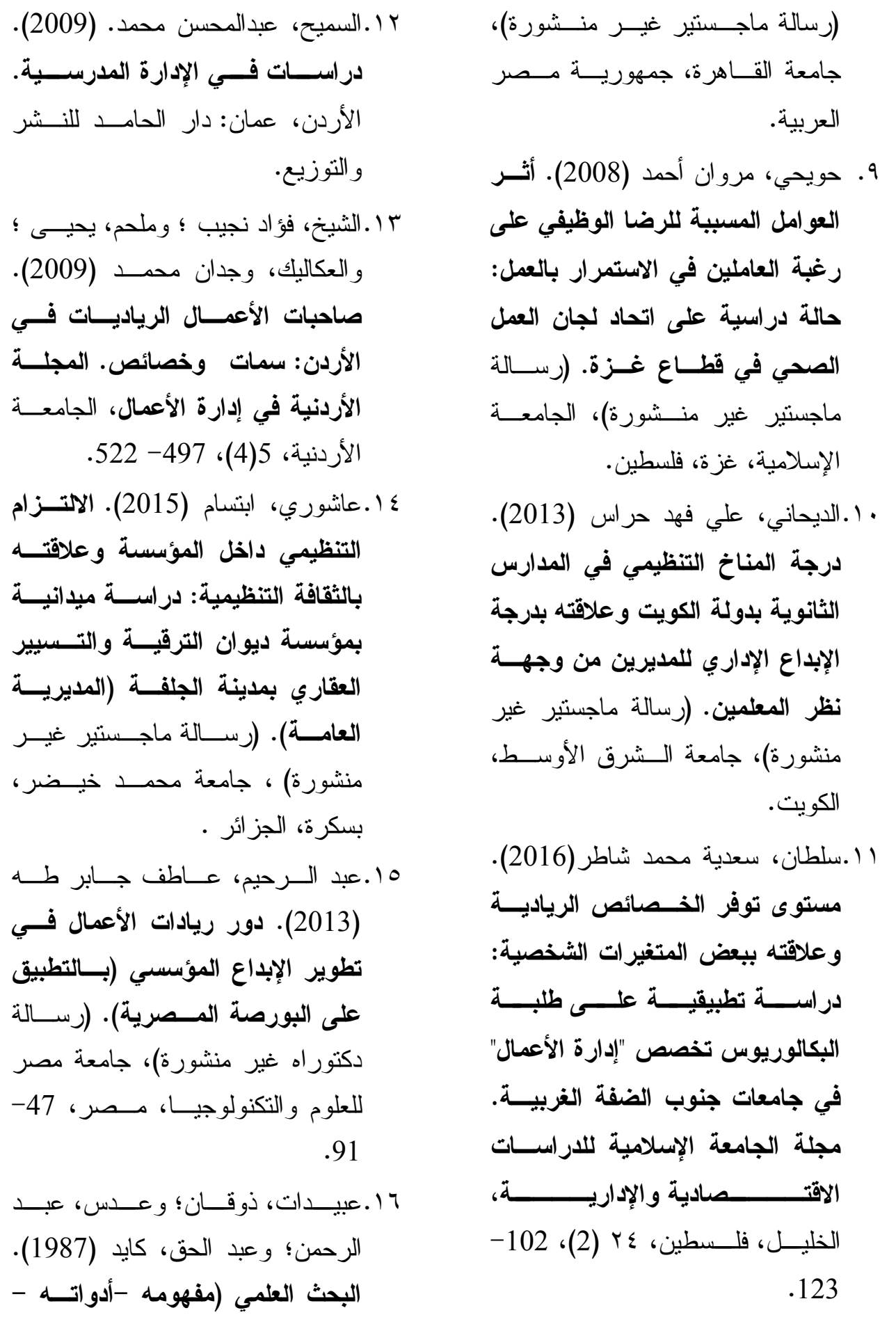


ا Y. غنــام، محمــود رضــــوان محمــود

(2017). أثر الخــصائص الرياديــة

لاى الإدارة العليا في تبني التوجهات الترن

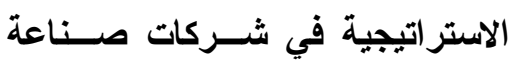

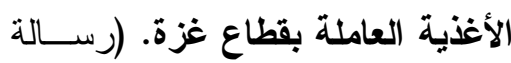

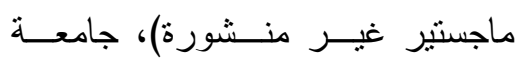
الأز هر، غزة، فلسطين.

r. بارس، نادين خالد (2016). العلاقـــة

بين الخصائص الريادية لاى الإدارة العليا في البنوك التجارية والتخطيط الاستر اتيجي في قطاع غزة: دراســة ميدانية على المــدراء فـــي البنــوك التجارية. (رســالة ماجسستير غيـر

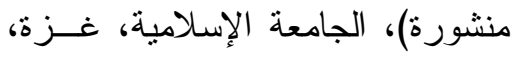
فلسطين. بץ.فلمبان، إيناس فؤاد نـــــو اوي (2007). الرضا الوظيفي وعلاقتـــه بــالالتزام التنظيمي لاى المشرفين التربــويين والمشرفات التربويات بإدارة التربية والتعليم بمدينة مكة المكرمة. (رسالة

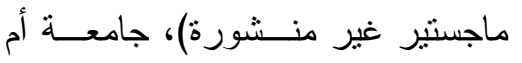
القرى، مكة المكرمة.

צ r.القاسم، مي منذر موسى (2013). أثر

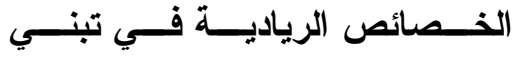
التوجيهات الاستر اتيجية للمديرين في المدارس الخاصة في عمان • (رسالة ماجستير غيــر منـشئورة)، جامعسـة
أساليبه )، الأردن، عمان: دار الفكر

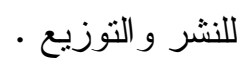
IV الخصائص الريادية في جودة الخدمة

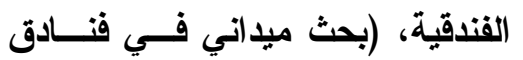

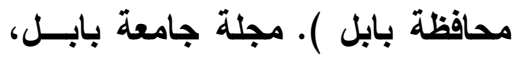

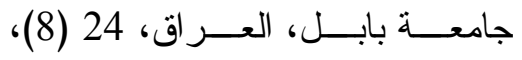
$.2172-2140$ 1 ا ـالعواوده، ســامية عبــداله (2015). القيادة التحويلية وأثرها على الالتزام

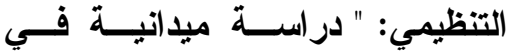
مديريات التربية والتعلــيم الأردنيـــة دئة في إقليم الوسط. (رســالة ماجسـتير

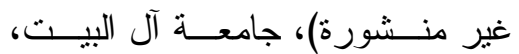
الأردن. 9 1 الالعوفي، محمد غالب (2005). الثقافة

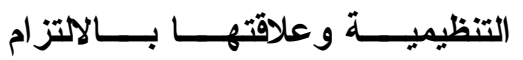
التنظيمي: دراسة ميدانية على هيئة الرقابة والتحقيق بمنطقة الريــاض.

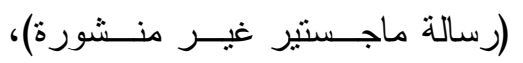
جامعة نايف العربية للعلوم الأمنيـــة،

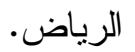
•r.r.الغامدي، سعيد محمد (2009). النمط

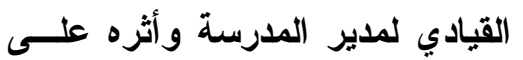
الالتزام التنظيمي بالمدارس الثانوية بمحافظة جدة. (رسالة ماجسنتير غير بالمان

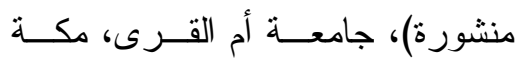

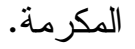


التي يتبعها مديرو مـــارس وكالــة

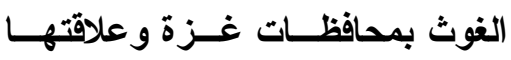
بالالتزام التنظيمـــ (رسالة ماجستير غير منشورة)، الجامعـــة الإســـلامية، غزة، فلسطين.

9ץ.المري، ياسر سالم (2013). ريسـادة الأعمال الصغيرة و المتوسطة ودورها

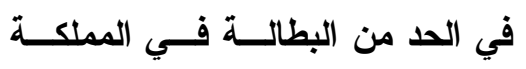

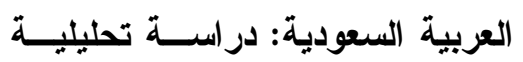

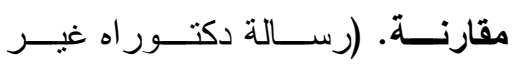
منشورة)، جامعة نايف العربية للعلوم الأمنية، الرياض، المملكـــة العربيـــة السعودية.

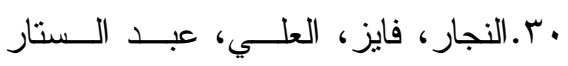

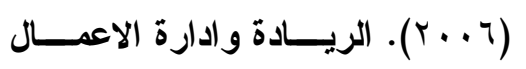
الصغيرة. دار الحامد لنشر و التوزيع، عمان، الأردن. اس.النفيعي، مزنة عوض. (2015). و اقع الاقدن استراتيجيات الريادة في الجامعـات السعودية: دراسة ميدانية على جامعة الملك سعود. مجلة الإدارة العامــة،

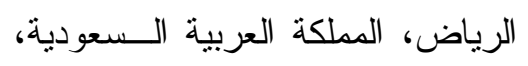
55 (4) $518-665$

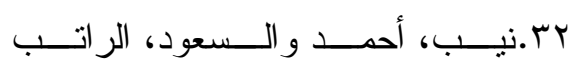
(2014). درجة ممارسة قيم العمـل لــل

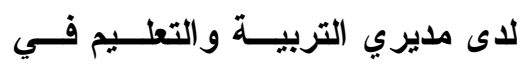
الأردن وعلاقتهــــا بـرجـــة الالتـــزام
الثرق الأوسط، عمان، الأردن. هץ.القحطاني، ســالم سـعيد آل ناصـر (2015). الريادة الاستر اتيجية كمدخل

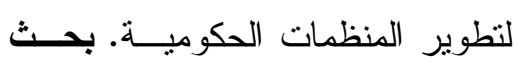
مقدم للمؤتمر الثاني لمعاهــــ الإدارة

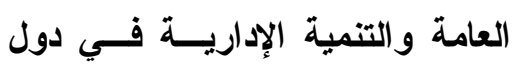
مجلس التعاون لدول الخليج العربية.

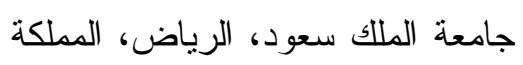
العربية السعودية، المحــور التــاني: التحول و التغيير في القطاع الحكومي، $.282-225$ צr.القرنة، لميس يوسف أحمد (2014).

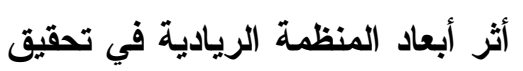

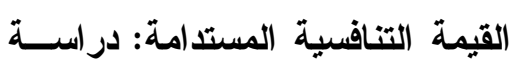
ميدانية في المـشروعات الــصغيرة و المتوسطة الحجم في مدينة عمان.

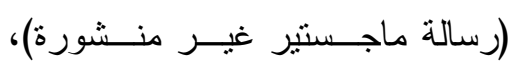

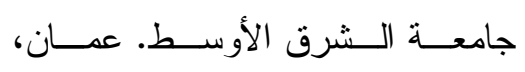
الأردن.

r. Y . Tريدي، باسم عباس (2010). الأنماط القيادية وأثرها في الالتزام التنظيمي: بالئ

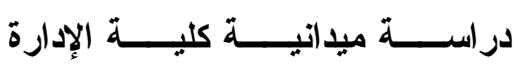

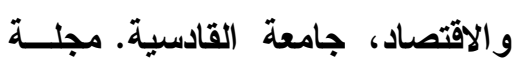

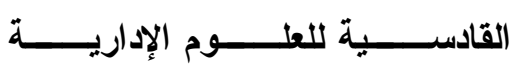
والاقتصادية،12(3)، 22- 44.

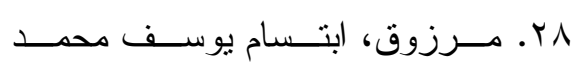
(2011). استر اتيجيات إدارة الصراع لوناع 
37. Hyrsky, K., \& Tuunanen, M. (1999). Innovativeness and risk-taking prospensity: A cross-cultural study of Finnish and US entrepreneurs and small business owners. Liiketaloudellinen aikakauskirja, 238-256.

38. Johansen, V., Schanke, T., \& Clausen, T. H. (2012). Entrepreneurship education and pupils' attitudes towards entrepreneurs. In Entrepreneurship-Born, Made and Educated. InTech.

39. Nagar, $\mathrm{K}$.

(2012). Organizational commitment and job satisfaction among teachers during times of burnout. Vikalpa, 37(2), 43-60.

40. Okhomina,D.A.(2010).

Entrepreneurial postures and psychological traits: the sociological influences of education and environment. Research in Higher Education Journal, 1(8): 1-20

41. Reynierse,J. H., Harker, J. B., Fink, A. A., \& Ackerman, D. (2001).Personality and perceived business values: Synergistic effects for the Myers-Briggs type indicator and management ratings. International Journal of ValueBased Management, 14(3), 259-271.
التظظيمي لرؤساء الأقسام العـاملين

معهم. مجلة دراسات العلوم التربوية،

جامعة عمان العربية، الأردن، (41)، معهم، $.19-1$

33. Aydin, A., Sarier, Y., \& Uysal, S. (2013). The Effect of School Principals' Leadership Styles on Teachers' Organizational Commitment and Job Satisfaction. Educational sciences: Theory and practice, 13(2), 806-811.

34. Ghina, A. (2012). The influence of corporate culture on organisational commitment: Case study of civil government organisations in Indonesia. International Journal of Basic \& Applied Sciences, 1(2), 156170 .

35. Hawkins Jr, D. W. (1998). Predictors of affective organizational commitment among high school principals (Doctoral dissertation):1-113

36. Hulpia,H.,Devos,G.,\& Rosseel, Y. (2009). The relationship between the perception of distributed leadership in secondary schools and teachers' and teacher leaders' job satisfaction and organizational commitment. School Effectiveness and School Improvement, 20(3), 291-317. 
44. Yavuz, M. (2010). The effects of teachers' perception of organizational justice and cultureonorganizational commitment. African Journal ofBusiness Management, 4(5), 695.

45. Yu Cheng, M., Sei Chan, W., \& Mahmood, A. (2009). The effectiveness of entrepreneurshipeducation in Malaysia. Education and Training, 51(7), 555-566.

46. Zimmerer,T.W.,Scarborough, N. M., \& Wilson, D. (2005). Essentialsofentrepreneurshipa ndsmalbusiness management. Pearson/Prentice Hall :1-16
42. Sikalieh,D., Mokaya, S. O., \& Namusonge,M.(2012).The concept of entrepreneurship; in pursuit of a universally acceptable definition. International Journal of Arts and Commerce , 1(7): 128- 135

43. Wilson, K. E., Vyakarnam, S., Volkmann, C., Mariotti, S., \& Rabuzzi, D. (2009). Educating thenextwave of entrepreneurs: Unlocking entrepreneurial capabilities to meet the global challenges of the 21st century: 1-184 